\title{
Epistemic Beliefs and
}

Conceptions of Competence

in Education for Sustainable

Development

Marie Grice 

Epistemic beliefs and conceptions of competence in education for sustainable development 



\section{Epistemic beliefs and conceptions of competence in education for sustainable development}

Marie Grice 
(C) GRICE MARIE, 2021

ISBN 978-91-7963-087-4 (printed)

ISBN 978-91-7963-088-1 (pdf)

ISSN 0436-1121

Doctoral thesis in Pedagogical work at the Department of Pedagogical, Curricular and Professional Studies, University of Gothenburg.

The publication is also available in full text at:

http://hdl.handle.net/2077/69896

Subscriptions to the series and orders for individual copies sent to: Acta Universitatis Gothoburgensis, PO Box 222, SE-405 30 Göteborg, Sweden or to acta@,ub.gu.se

This doctoral thesis has been prepared within the framework of the graduate school in educational science at the Centre for Educational and Teacher Research, University of Gothenburg.

Centre for Educational Science and Teacher Research, CUL

Graduate school in educational science

Doctoral thesis 95

In 2004 the University of Gothenburg established the Centre for Educational Science and Teacher Research (CUL). CUL aims to promote and support research and thirdcycle studies linked to the teaching profession and the teacher training programme. The graduate school is an interfaculty initiative carried out jointly by the Faculties involved in the teacher training programme at the University of Gothenburg and in cooperation with municipalities, school governing bodies and university colleges.

Print:

Stema Specialtryck AB, Borås, 2021 


\begin{abstract}
Title: $\quad$ Epistemic beliefs and conceptions of competence in education for sustainable development

Author: $\quad$ Marie Grice

Language: English

ISBN: $\quad$ 978-91-7963-087-4 (printed)

ISBN: $\quad$ 978-91-7963-088-1 (pdf)

ISSN: $\quad 0436-1121$

Keywords: education for sustainable development, epistemic beliefs, teachers' ESD competences, measuring instruments, exploratory factor analysis, philosophizing with, ethical competence, action readiness
\end{abstract}

Education for sustainable development (ESD) raises critical questions regarding what knowledge should be taught and what the learning outcomes should be. The aim of this thesis is to explore epistemological, ethical, and critical dimensions of ESD. There are two empirical sites. One is a transdisciplinary educational project with upper-secondary Swedish students $(n=208)$ from 16 different schools; the other involves teachers $(n=158)$ at a large Swedish upper-secondary school implementing ESD.

The research design is emergent, combining empirical and theoretical studies. A questionnaire instrument to explore students' epistemic beliefs (personal theories of knowledge and knowing) was constructed. Exploratory factor analysis identified five dimensions: transdisciplinary, certain, quick, collaborative, and simple knowledge. These showed predictive power in a multiple regression analysis. Another instrument was constructed to examine teachers' ESD competences. Four dimensions were identified.

Wicked sustainability challenges require the individual, education, and society to adopt new ways of thinking, learning, and acting. Calls for transformation, supported by supranational organizations, have contributed to an increased focus globally on competence-oriented knowledge in the curriculum. Ethical competence, action readiness, and normative competence are nested concepts explored theoretically in this thesis. Philosophizing with is a central method, which invites epistemology as a voice into the analysis. Transdisciplinary and pluralistic ESD allow for ethical issues to surface in the classroom. It is theorized that an ESD teacher needs to be both morally 
sensitive and ready to transform didactics in the teacher-learner nexus. One conclusion is that students' sophisticated epistemic beliefs may be important antecedents in transdisciplinary ESD. Another is that the element of action in the conceptualization of competence remains a critical aspect for educational research and practice. 


\section{Preface}

When I first began to work as a teacher in upper-secondary school, there were five lecturers, holding doctorate degrees, in physics, mathematics, technology, Swedish and English, at my school. I was inspired by them and started as a "shadow" PhD-student in English literature without funding. For a few years I tried to combine full-time teaching with research studies, but in the end I had to choose. Many years later, falling back on a long teaching experience of English and Swedish, an opportunity of funding from a governmental grant (Kammarkollegiet) emerged, and I was able to accept a position as a $\mathrm{PhD}$ student at the Centre for Educational Sciences and Teacher Education [CUL, Centrum för utbildningsvetenskap och lärarforskning] in Gothenburg. I got a licentiate degree in pedagogical work in 2014, and now, this second leg of research studies, towards a doctorate degree, the municipality of Uddevalla has kindly made it possible for me to study half-time, teaching half-time. Special thanks to my headmaster Tomas Ländström for being instrumental in making this professional development possible, and thanks to Stefan Einarsson, head of Uddevalla gymnasieskola, for investing in this knowledge project, endorsed by the local educational administration of Uddevalla municipality. Thank you!

I wish to express deep gratitude to my two supervisors Professor Olof Franck and Associate Professor Eva Nyberg. Under your guidance, I have developed my research skills and been able to participate in joint article writing, conference presentations, and engaged in deep thinking about what matters: knowledge, ethics and sustainability. I have learned from you and enjoyed it tremendously. You have been outstanding exemplars to share this experience with. I cannot thank you enough.

Despite being an external PhD-student, I have found the Department of Pedagogical, Curricular and Professional Studies a welcoming place full of hardworking and committed people, who have inspired me and helped me in practical ways too. I wish to mention a few of all you important people: Marlene Sjöberg, Miranda Rocksén, Annika Lilja, Christina Osbeck, Rebecca Hall Namanzi, Anette Strandberg, Kristina Sörensen and Dawn Sanders. I am grateful to Catherine Machale Gunnarsson for attending to linguistic challenges in my thesis. Any remaining mistakes are all my own! At CUL I would like to send out special thanks to Klas Eriksson, Jonas Emanuelsson and Ingela Bursjöö. It seems we go back a long way. 
More specifically, I would like to thank Helge Strømsø for being the discussant at the defence of my licentiate degree thesis; Jan-Eric Gustafsson for expert advice on statistics, and Leif Östman for your thorough reading of my thesis manuscript at the final seminar. There are of course a whole range of anonymous reviewers connected to the journals which have published my articles that deserve recognition. I am grateful for all supportive and instrumental advice I have received and for the odd harsh comment. I have learned from it all.

A few more research colleagues and friends that I would like to express my gratitude to are Ann-Marie Eriksson, Anna Mogren and Helene Grantz. Finally, I send a message of love and appreciation to my children Mina, Sara and Henrik Grice, my parents Karin and Kjell Jansson, and my dear sister Ann-Cathrin Johansson. 


\section{List of papers}

This article-based thesis is made up of the papers below. All published papers are reprinted with permission from the copyright holders and can be found in Part 2.

\section{Paper I}

Grice, M., \& Franck, O. (2014). A phronesian strategy to the education for sustainable development in Swedish school curricula. Journal of Education for Sustainable Development. 8(1), 29-42.

\section{Paper II}

Grice, M. (2014). Epistemic beliefs and knowledge creation among uppersecondary students in transdisciplinary education for sustainable development. Nordidactica. (1), 146-169.

\section{Paper III}

Grice, M., \& Franck, O. (2017). Conceptions of ethical competence in relation to action readiness in education for sustainable development. Reflective Practice. 18(2), 256-267.

Paper IV

Grice, M. (2017). Philosophizing with transdisciplinarity, relational knowledge and ethics in education for sustainable development, In O. Franck and C. Osbeck (Eds.) Ethical Literacies and Education for Sustainable Development: Young people, subjectivity, and democratic participation. Cham: Palgrave Macmillan.

Paper V

Grice, M., Mogren, A., Grantz, H., \& Gericke, N. (2018) Kompetenser för lärare inom utbildning för hållbar utveckling - konstruktion av ett enkätinstrument [Teacher competences in education for sustainable development - the development of a questionnaire instrument]. Pedagogisk forskning i Sverige, 23(3-4), 262-289.

\section{Paper VI}

Grice, M., \& Franck, O. (manuscript, 2021) Focusing on moral literacy and normative competence in education for sustainable development. 



\section{Author contributions}

Four papers were co-authored, according to the agreed-upon statements below. Paper I

Lead author is Marie Grice, co-author is Associate Professor Olof Franck. Whereas Franck focused on describing what is written regarding sustainable development in the syllabi, Grice contributed to a large extent by applying the analytical concepts of thick and thin, understood as world-guided and actionguiding respectively as well as suggesting the phronesian strategy for education for sustainable development.

\section{Paper II}

Sole author is Marie Grice, an empirical paper.

Paper III

Lead author is Marie Grice, co-author is Associate Professor Olof Franck. Franck contributed with aspects of ethical competence and values education in the literature review. Grice provided the analysis and the tentative concept of action readiness.

\section{Paper IV}

Sole author is Marie Grice, a theoretical paper (book chapter).

\section{Paper V}

Lead author is Marie Grice, co-authors are Anna Mogren, Helene Grantz and Professor Niklas Gericke. Anna Mogren contributed a literature review on the implementation of ESD, Grantz provided aspects of practical ESD in formal and informal education, Gericke assisted in making a clear presentation of the results. Grice focused on the concept of competence in the literature review, developed the research instrument, performed the statistical analyses, and elaborated the main part of the analysis.

\section{Paper VI}

Lead author is Marie Grice, co-author is Professor Olof Franck. Franck contributed a summary of Nancy Tuana's moral literacy theory. Grice provided the main part of the synthesis, making the paper a link between papers I-V and the frame of the present thesis. 



\section{Contents}

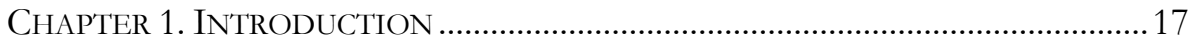

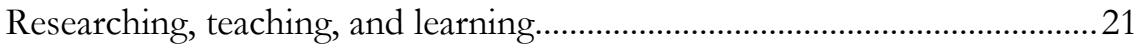

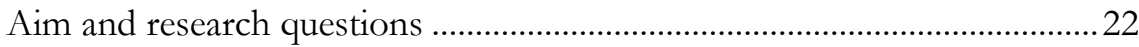

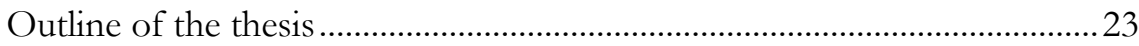

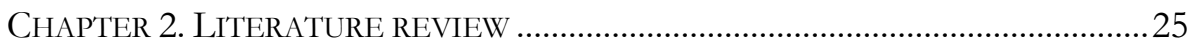

Personal epistemology and epistemic cognition ..........................................25

Epistemic flexibility and sophistication ......................................................2

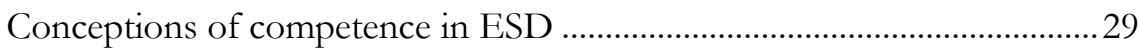

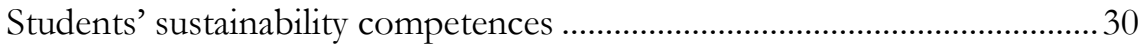

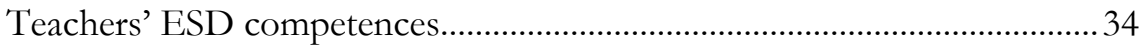

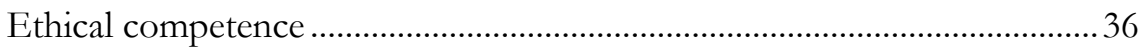

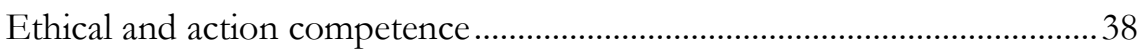

Summary of the literature review................................................................. 40

CHAPTER 3. THEORETICAL ORIENTATIONS ......................................................... 41

Epistemic beliefs and personal epistemology ............................................... 41

Transdisciplinary and transformative ESD ...................................................4

The competence-driven curriculum .............................................................46

CHAPTER 4. RESEARCH DESIGN AND METHODOLOGY ........................................51

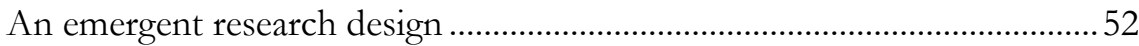

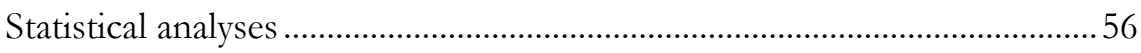

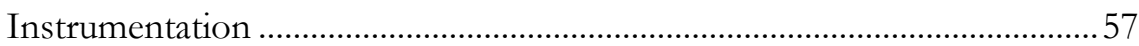

Empirical study of students' epistemic beliefs .................................................59

Empirical study of teachers' ESD competences..............................................6

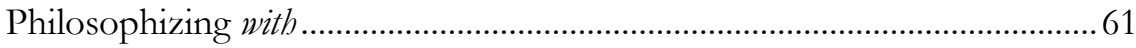

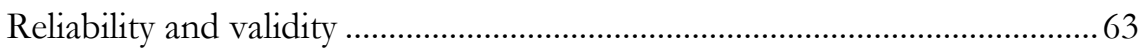

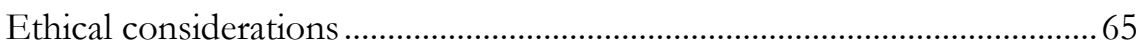

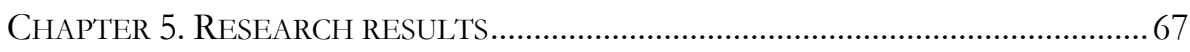

Paper I - A phronesian strategy to the education for sustainable development in Swedish school curricula. ...................................................67

Paper II - Epistemic beliefs and knowledge creation among upper-secondary students in transdisciplinary education for sustainable development 
Paper III - Conceptions of ethical competence in relation to action readiness in education for sustainable development ..................................................... 72 Paper IV - Philosophizing with transdisciplinarity, relational knowledge and ethics in education for sustainable development...........................................74 Paper V - Teacher competences in education for sustainable development the development of a questionnaire instrument. ............................................77 Paper VI - Focusing moral literacy and normative competence in education

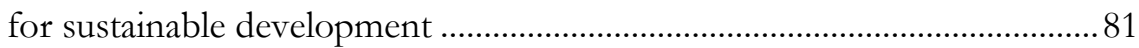
Synthesizing the empirical and the theoretical studies................................. 83

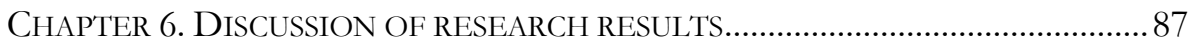

What epistemic beliefs can be identified among upper-secondary students involved in a transdisciplinary sustainability project?...................................... 87 What dimensions of teachers' ESD competences can be identified among teachers at an upper-secondary school?.......................................................... 92 How can moral literacy, and epistemic and ethical dimensions of ESD, be related to conceptions of competence? ......................................................... 93 Limitations of the studies ...................................................................... 96

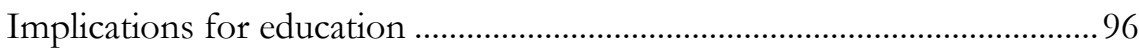

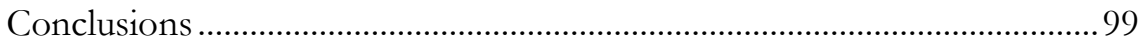

Engaging with an emergent research design and extended methodology 101

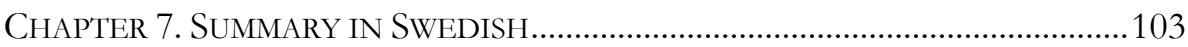

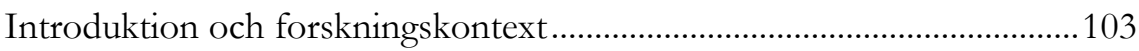

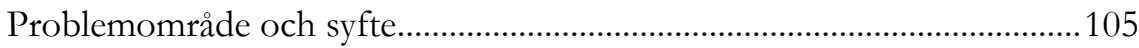

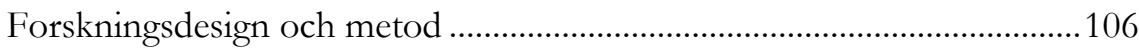

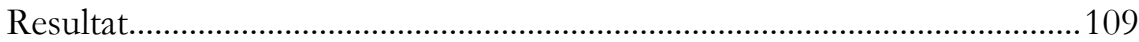

Diskussion och implikationer ......................................................................116

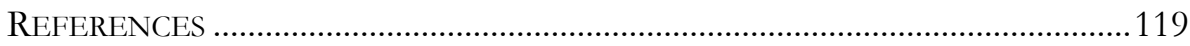

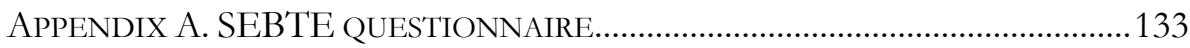

APPENDIX B. TESDC QUESTIONNAIRE ..........................................................136

APPENDIX C. ORAL INFORMATION TO THE PARTICIPANTS OF TESDC .........138 


\section{List of tables and figures}

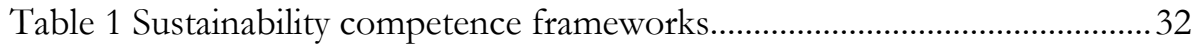

Table 2 Dimensions and processes referring to ethical competence..................37

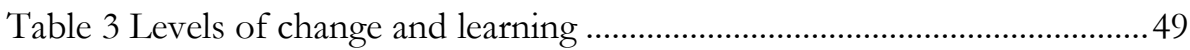

Table 4 Repeated and new items in SEBTE ......................................................5

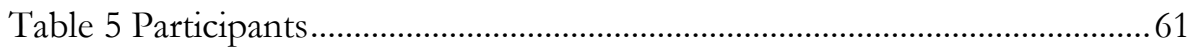

Table 6 Paper proposals at research conferences................................................65

Table 7 Factors from EFA and project evaluation items.................................... 70

Table 8 Multiple regression analysis, stepwise, model 7 ..................................... 71

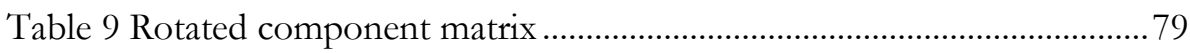

Table 10 Overview of papers, main approaches, methods and concepts ........ 85

Table 11 Types and levels of change, knowledge, and learning in ESD.......... 98

Figure 1 Illustration of the exploratory and emergent research design .............54

Figure 2 Results flowchart of papers I-VI....................................................... 83 



\section{Chapter 1. Introduction}

The environmental assessments and geo-scientific messages are clear. The carrying capacity of the planet is on the brink of being surpassed and could lead to irreversible damage to the biosphere (IPCC, 2021). Meeting the Sustainable Development Goals by 2030 is necessary but will prove a challenge. In an urgent time of climate change and the Covid-19 pandemic active citizens and education that set out to meet such challenges are required. Entangled with this are also issues concerning a knowledge crisis. Students have unprecedented access to information and need to process both diverse and contradictory facts through new technology (Muis, Pekrun, Sinatra, Azevedo, Trevors, Meier, \& Heddy, 2015). A vital effort in education is thus to foster students' critical thinking and vigilance regarding the reliability of sources. One conclusion that can be drawn from this is that epistemology and sustainability are intertwined. Thus, it becomes important for students to think about what knowledge is and how they come to know something. In psychological and educational research this is referred to as epistemic cognition. In this thesis the interest in students' epistemic cognition is set off against global concerns of sustainability.

A widely accepted definition of sustainable development is the one in the Brundtland report, to meet the needs of the present without compromising the ability of future generations to meet their own needs (World Commission on Environment and Development, 1987, p 24). Education for sustainable development (ESD) is an educational response to sustainable development, with the aim of supporting and promoting a sustainable future. In the Swedish school curricula of 1994 and 2011 environmental perspectives were brought forward together with historical, international and ethical (Hillbur, Ideland, \& Malmberg, 2016). There is further a call for education to work with norms and values, respect for and care about the environment, knowledge about and for a healthy biosphere. Sustainability education is one of the fields employing the concept of sustainability (Wolff, 2020), another one is sustainability science (Barth \& Michelsen, 2013), which is based on systems thinking and the interaction between natural and social systems (Michelsen, Adomßent, Martens, \& Von Hauff, 2016). In addition to aspects of ecology, society and economy, there are 
ethical and political issues such as the responsibility for future generations and global issues of justice. Equity and justice are two major drivers of sustainable development (Schneider, et al., 2019), and consequently of education for sustainable development (ESD), which is one object of knowledge for this research project.

As ESD to a large extent is about understanding various challenges for the ecological, economic and social systems, it involves an openness to new ways of knowing and knowledge production. One such approach is transdisciplinarity, which reaches out epistemically, across and beyond various disciplines. In progressive education, new approaches to teaching and learning are applied, such as interdisciplinary, multidisciplinary, and transdisciplinary education (Schneider, et al., 2019). All such approaches include epistemological issues of who knows what, how they know and how we can be certain that something is the case. Students' theories about knowledge and knowing, their epistemic beliefs, are studied in the fields of education and psychology, through personal epistemology and epistemic cognition. This is a growing area of research that has linked epistemic beliefs to academic success (Greene, Cartiff, \& Duke, 2018; Schommer, 1990). The complexities of ESD rest both on the transdisciplinary mode of learning, and also on the possibility of encountering contradictory scientific facts (VanPoeck, 2019).

The interest in transdisciplinarity can be related to the participatory turn in democracies towards civic science, which invites citizens to produce, validate and apply scientific knowledge (Bäckstrand, 2003; Læssøe 2010). This coconstruction of knowledge is underpinned by democratic-normative as well as epistemic dimensions. With such an agenda there are many social issues that can be addressed in ESD. The good society is one that is characterized by gender equity, multi-ethnic inclusiveness, poverty erasure and education for all (Osborn, 2013). In this thesis, it is recognized that the transdisciplinary approach presents an openness to various epistemologies, an interest it shares with for example feminist theory (Lykke, 2010), which aims to highlight the injustices in epistemologies, the epistemologies that are excluded in science and the ones that are biased against women. An interdisciplinary approach, which builds on and allows for more inclusive, varied thinking and acting in the world when engaging with ethical issues, can address the injustice, bias, and deficiency of normative, traditional epistemologies (Romm, 1998). However, these issues are not the focus of this thesis, which addresses transdisciplinarity conceptually. 
The concept of competence was introduced worldwide in curricula half a century ago. Especially in vocational and professional education, there was a dissatisfaction that education failed to sufficiently prepare the students for the job market. Education was perceived as a place for learning outside society and the teachers as having no real experience of the jobs they were preparing students for (Mulder, 2017). Instead of a subject-driven curriculum, which seemed detached from the real world, a competence-driven curriculum seemed to the real world in more than one way (Mulder, 2017). With sustainability as the major driving force in our world, economically, socially, and environmentally, not only is school reaching out to society, but also the reverse. The urgency of the matters of climate change, poverty, pandemics, and natural resource depletion reaches into school through, for example, the United Nations Decade of Education for Sustainable Development (DESD), the UN Global Action Programme and the Sustainable Development Goals, which all unite in the call for education to adapt, transform and take the lead (United Nations Educational, Scientific and Cultural Organisation, UNESCO, 2018). Expectations in transnational organizations' discourse are overoptimistic as education is limited by global as well as local economic issues (Wolff, 2020).

In research on the implementation of ESD the notion of transformation is prevalent (MacIntyre, Lotz-Sisitka, Wals, Vogel, \& Tassone, 2018; Sterling, 2014). It is possible to see development from environmental conservation and environmental education, which brought attention to biodiversity degradation and resource deterioration, via education for sustainable development which took a holistic approach to understanding wicked problems (Blok, Gremmen, Wesselink, 2015; Lönngren \& Van Poeck, 2020; Rittel \& Webber, 1973), thus including more than the ecological perspective through to transformative sustainability education, which presents a paradigm shift (Sterling, 2011) and is focused on the fact that we must not refrain from taking action. Both epistemic and ethical issues are raised concerning what it is to know and what sustainability is, all of which requires the attention of educational research.

The focus in this thesis is admittedly anthropocentric and solely concerned with theoretical conceptual analysis, while mindful of other possible scopes, including post-humanist stances and respect for the non-human species and more-than-human entities (Stickney \& Skilbeck, 2020). This does not suggest the ethical position of the researcher but explains that the scope of the research in this particular project concerns students' and teachers' individual and 
collective approaches to sustainable development in education and so in that respect the focus is anthropocentric.

The transformation that sustainable development requires has implications for conceptions of knowledge, education, the individual, and society (Wolff, 2020). In this thesis the starting point is a transdisciplinary educational project, which reached across several Swedish upper-secondary schools, involved extramural stakeholders, and resulted in students writing a book on food. The epistemic cognition of the participating students was explored using the construct of epistemic beliefs, beliefs about what knowledge is and how you come to know. The empirical study was followed by conceptual studies regarding conceptualizations of education for sustainable development in the Swedish curriculum, which highlighted the notions of ethical competence, action readiness and normative competence as theoretical contributions in ESD, all of which evolved out of the findings of the initial educational project. In the exploration and explications of these notions, the focus has been on how the conceptualization of competence can be extended and deployed in educational research and practice. The dimensionality of ESD competence was then explored among teachers implementing ESD. This is the other object of research in this thesis. The link between students' ESD competence and teachers' professional ESD competence is reflected in the United Nations Education for Sustainable Development Goals, SDG 4 (UNESCO, 2018). SDG 4 raises critical questions regarding what knowledge should be taught and what learning outcomes should be in relation to new demands on teachers' competences to respond to sustainability challenges.

This is an article-based thesis incorporating four articles, a book chapter and a manuscript, extending and expanding on my licentiate-degree thesis ${ }^{1}$. It broadens the perspectives of the two studies in the licentiate-degree thesis both theoretically and empirically by further examining what knowledge and competence might be in ESD and how students and teachers can make use of them in didactical practice. This thesis is mainly concerned with and rooted in fields of study that focus on epistemological, ethical, and critical reflection. The results are relevant to educational practice, curriculum, school development and policy.

Grice, M (2014) Epistemic beliefs among upper-secondary students in education for sustainable development. http://hdl.handle.net/2077/37807 


\section{Researching, teaching, and learning}

This research project was carried out across two periods of $\mathrm{PhD}$ studies at the Graduate Research School in Educational Sciences, at the University of Gothenburg. Before, during and between the two study periods, I have been teaching at Uddevalla gymnasieskola [upper-secondary school], where my research problems originated. My colleagues and I have been involved in transdisciplinary projects about sustainability with our first-year students in the technical programme, for example projects about energy, water, and food. About 90 students a year have been involved in those projects, resulting in studentproduced exhibitions and books ${ }^{2}$. Two projects were organized together with several other schools and an external stakeholder, Global Forum, which was an organization in western Sweden initiating dialogues about globalization and its consequences. The empirical study regarding students' epistemic beliefs was situated in the project regarding food.

Throughout the whole period of $\mathrm{PhD}$ studies, I have been involved in course development at Uddevalla gymnasieskola, especially the course Building a sustainable society in the technical programme together with colleagues. A contribution to that course relevant to my thesis is the establishment of a transdisciplinary project with the municipality of Uddevalla, the town planning section, in which the students (18-19 years old) work in a whole-class project with a locally relevant issue. The issues to be approached are identified by the local government. We have mainly been involved in the development of green spaces and parks in Uddevalla. The students collect data from citizens, commuters, and visitors to Uddevalla and conduct quantitative and qualitative analyses, the results of which have been used by local town planners. Moreover, the results are presented publicly and provide an opportunity for citizenship dialogue, orchestrated and driven by the participating school students.

Thus, parallel to my research process, I have been able in my teaching practice to explore and experiment with the problem area of and relevant concepts in this thesis. My teaching in upper-secondary school has provided a practical mooring for the reflective analyses.

Magnusson, Å \& Nilsson, B (2013) Mat! 351 västsvenska ungdomar om global matsäkerhet och bållbar utveckling [Food! 351 young people in Western Sweden on global food security and sustainable development]. Göteborg. Tre böcker. This is the book written by students who participated in the study on epistemic beliefs (Paper II). 


\section{Aim and research questions}

The aim of this thesis is based on three concerns about education for sustainable development and about transdisciplinary education specifically, but it raises issues relevant to practical pedagogical work and educational research in general. First, a concern is how students' epistemic beliefs (theories about knowledge and knowing) might impact how students orient themselves in transdisciplinary ESD. A second concern is what ESD competences can be found among in-service teachers who aim to implement ESD. In the two empirical studies there are various layers of complexity of the research problem. One layer concerns the practical teaching-learning nexus of education for sustainable development, and another the conceptual possibilities regarding what ESD might be. In both layers of complexity, competences seem to be a productive educational concept for the intended learning-teaching outcomes. A third and broad concern is how to approach the complexity of the object of research in ESD. These are epistemological issues, in one sense subject-specific, even topic-specific, but in another sense, broad and domain-general. There are also ethical issues in relation to what ESD is about and how it is orchestrated. It therefore seems reasonable to expect that dimensions of ethical competence are required in transdisciplinary education, where students may encounter intraas well as interpersonal issues. Thus, the thesis attempts to extend our understanding of epistemic beliefs and conceptions of competence relevant to addressing issues of sustainability. The specific research questions are:

RQ1. What epistemic beliefs can be identified among upper-secondary students involved in a transdisciplinary sustainability project?

RQ2 What dimensions of teacher competences in the context of ESD can be identified among teachers at an upper-secondary school?

RQ3. How can moral literacy, and epistemic and ethical dimensions of ESD be related to conceptions of competence? 


\section{Outline of the thesis}

Part 1 contains the frame of this doctoral thesis, incorporating a few passages slightly adapted from my licentiate thesis ${ }^{3}$. After the introduction and the research aims, the research context and a selection of previous studies are presented in Chapter 2. Theoretical frameworks of epistemic beliefs and conceptions of competence are laid out in Chapter 3. Research design, methodology and the interrelationship between statistical and interpretative methods applied to the various studies are presented in Chapter 4. Chapter 5 summarizes the main findings of the papers that this thesis is based on. Chapter 6 includes the discussion of the results and engages with the implications for practice. A summary of the thesis in Swedish makes up Chapter 7. Part 2 consists of the six papers that this thesis is based on: four published articles, a published book chapter and an unpublished manuscript.

3 Grice, M (2014) Epistemic beliefs among upper-secondary students in education for sustainable development. http://hdl.handle.net/2077/37807 



\section{Chapter 2. Literature review}

As was pointed out in the introduction, the focus in this thesis project is related to several fields of research, such as education for sustainable development, personal epistemology and ethics. Because of the wide-ranging aims of this thesis, a review of previous research will be limited from the point of view of each field of research. For that reason, this literature review concentrates on a few seminal and varied studies rather than addressing the full range of literature across the relevant fields. The selected literature frames the educational context of transformative education for sustainable development, especially regarding students in upper-secondary school, the empirical and theoretical concepts of epistemic beliefs, and the notion of competence in the research context of ESD.

\section{Personal epistemology and epistemic cognition}

What do I know and how do I know what I know are typically philosophical questions that have occupied epistemologists for centuries. Epistemology is a branch of philosophy that is concerned with how we know that something is the case, what constitutes knowledge and how you come to know, and what the nature of knowledge and knowing is. It is only in the last few decades that educational researchers have directed attention to students' assumptions about those questions as predictors of academic success. Epistemic beliefs are individuals' personal beliefs and theories about knowledge and knowing (Bromme, Pieschl, \& Stahl, 2010; Hofer, 2004). Pintrich's well-known definition of personal epistemology (PE) is that it is an individual's cognition about the nature of knowledge and the nature of knowing. Kitchener (2002) sees it as an individual's unique construction of a theory of knowledge. In short, it is an individual's thinking about thinking in relation to knowledge. PE is a research area with potential as it connects research and teaching by looking at students' creative and critical thinking and providing pedagogical advice on the results (Holma \& Hyytinen, 2015).

William G. Perry Jr began his influential work of personal epistemology at Harvard university. In a longitudinal study with male college students at Harvard and Radcliffe during the fifties and early sixties, Perry (1968) and his 
team tried to illustrate a variety of student responses to a culture of contingent knowledge and relative value. His concern was not the epistemic beliefs per se, but rather the ethical and intellectual development of the students. A checklist of educational views (CLEV) was used to select the participants. The aim of CLEV was to identify student profiles ranging from dualistic to contingent thinkers. Using the thick descriptions of continual interviews during the participants' years at university, the research team created a developmental scheme on the assumption that it is possible to identify a dominant form of structure for each person. Perry, who was interested in how students experienced pluralistic education, postulated from his research nine developmental positions (Perry, 1968), centring on position five, in which knowledge is seen as contingent and relative. The nine positions were divided into three phases of: modifying dualism, relativism, and commitments (Perry, 1968, p. 57). The main line of development was from position one, where the student believes in right answers and things are seen as black or white, through to position nine where:

The student experiences the affirmation of identity among multiple responsibilities and realizes Commitment as an ongoing, unfolding activity through which he expresses his lifestyle (Perry, 1968, p. 10).

Perry's work was influenced by Piaget's theory of childhood development. According to Hofer and Pintrich (1997), Perry was the first researcher to claim that how students made sense of their education reflected a developmental process rather than a particular personality (Hofer \& Pintrich, 1997). Piaget postulated four stages of intellectual development of children up to the age of twelve. At the fourth stage, the child is capable of formal intellectual operations. This intellectual level means that the child is now capable of metacognition, of thinking about his or her own thinking (Wankat \& Oreovicz, 1993). Both Perry and Piaget were interested in the way children or university students move from one level or position to another. When the students believe that their knowing and values are relative in time and circumstance; and when they take responsibility and make a commitment to the kind of person they are, they will have reached the highest level (Perry, 1968). Commitment suggests ethical decisions and actions, and genuine transformation (Illeris, 2004). Following Perry, several models of epistemological development and thinking have been suggested through longitudinal studies (Belenky, Clinchy, Goldberger, \& Tarule, 1986; King \& Kitchener, 1994). 
The relationship between students' epistemic beliefs and motivation and academic success has been established by several empirical studies (Bråten, Ferguson, Anmarkrud, Strømsø, \& Brandmo, 2014; Bråten \& Strømsø, 2004; Buehl \& Alexander, 2005; DeBacker \& Crowson, 2006; Guo, Hu, Marsh, \& Pekrun, 2021; Hofer, 2004; Hofer \& Pintrich, 1997; Mason, Boscolo, Tornatora, \& Ronconi, 2013; Ricco, Schuyten, \& Medinilla, 2010; Schommer, 1993; Schommer-Aikins, 2004; Winberg, Hofverberg, \& Lindfors, 2019).

\section{Epistemic flexibility and sophistication}

Marlene Schommer (1990) further developed Perry's research and introduced a quantitative approach (Schommer-Aikins, 2004). Whereas Perry had been looking at the development of epistemic beliefs, Schommer directed the focus towards epistemic beliefs as a belief system. According to this belief system, the dimensions of knowledge operate independently of each other, so students might display various degrees of each dimension. The dimensions are believed to develop asynchronously. Schommer identified five dimensions of epistemic belief: the stability of knowledge, the structure of knowledge, the source of knowledge, the speed of knowledge acquisition, and the control of knowledge acquisition. Drawing on Ryan (1984), she introduced a paper-and-pencil, selfcompletion questionnaire, the Epistemological Questionnaire (EQ) which has played a major role in subsequent research on epistemic beliefs (Hofer \& Pintrich, 1997)

Schommer established a relationship between students' epistemic beliefs and students' overall academic performance among secondary students (Schommer, 1993). There was a minor indication that girls might have an advantage over boys in the fact that they differed in their belief in quick learning and fixed ability (1993). Students' grade point averages (GPA) were regressed on the factor scores and the students' IQ. Having a high IQ and less belief in quick learning, simple knowledge, fixed ability, and certain knowledge, improves the chances of having a better GPA. Even if it cannot be concluded from Schommer's study, it is plausible that students who believe in fixed ability will adapt their study strategy accordingly. This suggests that a student who is at the lower end of the continuum, believing that ability is fixed from birth, may not think of any strategies to solve an issue, but may adopt a passive, almost helpless attitude. Believing in a fixed ability to learn will make it all the harder to persist in solving complex tasks. In the same vein, Schommer claims that 
there is support for the idea that the student believing in simple knowledge (ranging from the belief that knowledge is best characterized as isolated bits and pieces to the belief that knowledge is best characterized as highly interrelated concepts) will find comprehension of complex texts difficult. With a naïve conception of the dimension of simple knowledge, the student is less likely to use integrative study strategies (Schommer, 1993). By contrast, students who are at the higher end (more sophisticated) of the continuum may believe that ability is improvable and therefore be more motivated to work hard (Schommer, 1993). Consequently, teaching less sophisticated (complex) views could foster naïve epistemic beliefs, which seems to make students less prepared for academic studies in that they will not be critical thinkers (Azevedo \& Torney-Purta, 2008)

Closely related to academic performance and school achievement are notions of goal-orientation and motivation. Bråten and Strømsø (2004) studied how epistemic beliefs functioned as antecedents to achievement goals among 80 Norwegian student teachers (19 to 46 years old). Other constructs that may predict the adoption of goals are motivation and competence expectancy, and the same constructs predict fear of failure (Bråten \& Strømsø, 2004). Both epistemic beliefs and implicit theories of intelligence beliefs were measured in a longitudinal study. The Schommer 63-item Epistemological Questionnaire was used in a Norwegian version. However, the factor analysis was item-based and not based on the prespecified subsets of beliefs that Schommer used in her factor analysis (Bråten and Strømsø, 2004). Bråten and Strømsø’s findings support the idea that students who believe that learning is quick are less likely to adopt mastery goals and more likely to adopt performance-avoidance goals. The belief in stable knowledge, passively achieved, revealed a similar result. Such beliefs can be a barrier for students when it comes to self-improvement. The effort involved in a laborious task might not seem worth it to students who believe in quick learning and stable knowledge. Bråten and Strømsø’s advice is that post-secondary education should pay attention to the belief in quick learning among students due to the barrier it presents to goal adoption.

It is not easy to get an overview of the field of personal epistemology in a Swedish research context. There seem to be few studies concerned with the epistemic beliefs of upper-secondary students. One of the reasons for this might be that the results can be found across several studies and that several concepts correspond to the same construct (Hofer, 2004). However, on their website, the Swedish National Agency for Education has disseminated research 
from two studies, a Norwegian one and a Taiwanese one, in addition to a review by Hofer and Pintrich (Skolverket [Swedish National Agency for Education], 2016). Together with a Swedish thesis from 2018 (Lindfors, 2018), this indicates that the research field is gaining attention in Sweden and that the results are perceived as practice-oriented and relevant to in-service teachers. Epistemic beliefs have been studied both as domain general and domain specific. In Lindfors' thesis, epistemic beliefs in the context of chemistry and natural science were explored across Swedish and German students in years 5 to 11 (Lindfors, 2018). Applying a multimethodological design, data was gathered using a questionnaire instrument, observation and interviews. This allowed Lindfors to explore students' epistemic practices, including epistemic beliefs and epistemic cognition. A difference between Germany and Sweden was identified in the correlation between epistemic beliefs and the learning environment of the classroom. There seem to be cultural differences between how students interpret teacher support. Teacher support in the German classroom corresponded to naive beliefs, where the teacher was seen as the source of knowledge. In the Swedish classroom, teacher support corresponded to the belief that knowledge is changeable and need to be motivated (Lindfors, 2018). Such cultural differences are not addressed in the present thesis, but indicate that epistemic beliefs may vary between cultures and classrooms. However, an important conclusion is that epistemic beliefs are shown to be important antecedents in relation to several aspects of pedagogical work. In Chapter 3, further theoretical aspects of personal epistemology are laid out.

\section{Conceptions of competence in ESD}

One way of defining sustainability is to refer to it as dealing with wicked problems. What makes the problems wicked is that neither the understanding of the problem nor its solution is definite, but both are complex. Simple solutions do not exist, and cause and effect are uncertain (Blok, Gremmen, \& Wesselink, 2015). Such complexities do not reside only in the practical situations of solving the problem and making decisions, but impact various epistemic and moral dimensions. In response to the complexity of sustainability problems, ESD competencies as educational outcomes and aims have gained focus in recent years and been identified as a specific field of research (Kramming, 2017; Mochizuki \& Fadeeva, 2010; Mogensen \& Schnack, 2010; 
Rieckmann, 2012; Wesselink \& Wals, 2011, Wiek, Withycombe \& Redman, 2011).

Competence has been defined as the aim of ESD, but it is a contested concept due to its inconclusive theory, which some authors find weak (Mulder, 2017; Rieckmann, 2012). Critics find that the concept of competence is burdened with a narrow, instrumental conceptualization of knowledge, in which the measurability of levels of action competence in relation to a specific aim seems to be highlighted (Gonczi \& Hager, 2010; Nordin, 2012). Among educators, the concept of competence is looked upon with some suspicion because of the obvious risk of oversimplifying the epistemic goals of education (Beckett, 2012; Lum, 2013). One of the suggestions put forward by Claxton (2009) is that complex performances as an epistemic goal of education are dissembled into component skills that could be developed or practised separately in education. Claxton points out that it is an oversimplification to assume that such cognitive sub-routines are reassembled in the individual learner. Similarly, it cannot be taken for granted that the separate practice of various sub-routines can rapidly create a mental capacity in the learner to construct and evaluate explicit, reasoned argument (2009, p. 183).

Despite its critics, the concept has gained attention not the least as a concept of knowledge. As Nordin (2012) proposes, competence goes beyond knowledge. It widens the understanding so that more general competences are encompassed in addition to the subject matter knowledge itself (Nordin, 2012). An advantage of the concept of competence from an epistemological point of view is that the concept offers an adaptability and flexibility in the competent individual to meet a complex and rapidly changing world (Öhman \& Sund, 2021). The definition of competence that is of interest in this thesis can be described as extended, integrated, and holistic (Beckett, 2012; Hager \& Beckett, 1995; Rieckmann, 2012). In such a conceptualization, cognitive, affective, and motivational aspects, are assumed to be included.

\section{Students' sustainability competences}

By the end of the UN Decade on ESD 2005-2014, the concept of competence was linked to all main developments in the field of education (Mathar, 2014). The competence orientation of ESD education has become a central component, and students' development of skills and competencies conforms to the idea of lifelong learning (Mathar, 2014). In a review article on key 
competences for ESD, Wiek et al. (2011) summarized several studies on sustainability competence, for example de Haan (2006) and Barth, Godemann, Rieckmann, \& Stoltenberg (2007). A framework was established consisting of five competences: system thinking, future thinking, normative competence, strategic competence, and an interpersonal competence (Wiek et al., 2011). In Table 1 below, they are contrasted with a recent synthesis of competences connected to aspects of ESD by a number of authors who have referred to them as key competencies or key competencies for or in sustainable development, Gestaltungkompetenz (shaping competencies), sustainability competencies or sustainability core competencies (Rieckmann, 2018): 
Table 1 Sustainability competence frameworks

\begin{tabular}{|c|c|}
\hline (Wiek et al., 2011; 2016) & (Rieckmann, 2018: 44-45) \\
\hline $\begin{array}{l}\text { Systems-thinking competence: the ability } \\
\text { to collectively analyse complex systems } \\
\text { across different domains (society, } \\
\text { environment, economy, etc.) and across } \\
\text { different scales (local to global), thereby } \\
\text { considering cascading effects, inertia, } \\
\text { feedback loops and other systemic features } \\
\text { related to sustainability issues and } \\
\text { sustainability problem-solving frameworks. }\end{array}$ & $\begin{array}{l}\text { Systems thinking competency: the ability } \\
\text { to recognize and understand relationships; to } \\
\text { analyse complex systems; to think of how } \\
\text { systems are embedded within different } \\
\text { domains and different scales; and to deal } \\
\text { with uncertainty. }\end{array}$ \\
\hline $\begin{array}{l}\text { Anticipatory competence: the ability to } \\
\text { collectively analyse, evaluate, and craft rich } \\
\text { "pictures" of the future related to } \\
\text { sustainability issues and sustainability } \\
\text { problem-solving frameworks. }\end{array}$ & $\begin{array}{l}\text { Anticipatory competency: the ability to } \\
\text { understand and evaluate multiple futures - } \\
\text { possible, probable and desirable; to create } \\
\text { one's own visions for the future; to apply the } \\
\text { precautionary principle; to assess the } \\
\text { consequences of actions; and to deal with } \\
\text { risks and changes }\end{array}$ \\
\hline $\begin{array}{l}\text { Normative competence: the ability to } \\
\text { collectively map, specify, apply, reconcile, } \\
\text { and negotiate sustainability values, } \\
\text { principles, goals, and targets. }\end{array}$ & $\begin{array}{l}\text { Normative competency: the ability to } \\
\text { understand and reflect on the norms and } \\
\text { values that underlie one's actions; and to } \\
\text { negotiate sustainability values, principles, } \\
\text { goals, and targets, in a context of conflicts of } \\
\text { interests and trade-offs, uncertain knowledge } \\
\text { and contradictions. }\end{array}$ \\
\hline $\begin{array}{l}\text { Strategic competence: the ability to } \\
\text { collectively design and implement } \\
\text { interventions, transitions, and transformative } \\
\text { governance strategies toward sustainability. }\end{array}$ & $\begin{array}{l}\text { Strategic competency: the ability to } \\
\text { collectively develop and implement } \\
\text { innovative actions that further sustainability } \\
\text { at the local level and further afield. }\end{array}$ \\
\hline $\begin{array}{l}\text { Interpersonal competence: the ability to } \\
\text { motivate, enable, and facilitate collaborative } \\
\text { and participatory sustainability research and } \\
\text { problem solving. }\end{array}$ & $\begin{array}{l}\text { Collaboration competency: the ability to } \\
\text { learn from others; to understand and respect } \\
\text { the needs, perspectives and actions of others } \\
\text { (empathy); to understand, relate to and be } \\
\text { sensitive to others (empathic leadership); to } \\
\text { deal with conflicts in a group; and to facilitate } \\
\text { collaborative and participatory problem } \\
\text { solving. }\end{array}$ \\
\hline \multirow[t]{2}{*}{$\begin{array}{l}\text { Integrated problem-solving competence: a } \\
\text { complementary to articulating the individual } \\
\text { contributions of the previous competences } \\
\text { and the ability to meaningfully integrate } \\
\text { problem analysis, sustainability assessment, } \\
\text { visioning and strategy building. }\end{array}$} & $\begin{array}{l}\text { Critical thinking competency: the ability to } \\
\text { question norms, practices and opinions; to } \\
\text { reflect on own one's values, perceptions and } \\
\text { actions; and to take a position in the } \\
\text { sustainability discourse. }\end{array}$ \\
\hline & $\begin{array}{l}\text { Self-awareness competency: the ability to } \\
\text { reflect on one's own role in the local } \\
\text { community and (global) society; to } \\
\text { continually evaluate and further motivate } \\
\text { one's actions; and to deal with one's feelings } \\
\text { and desires. }\end{array}$ \\
\hline
\end{tabular}




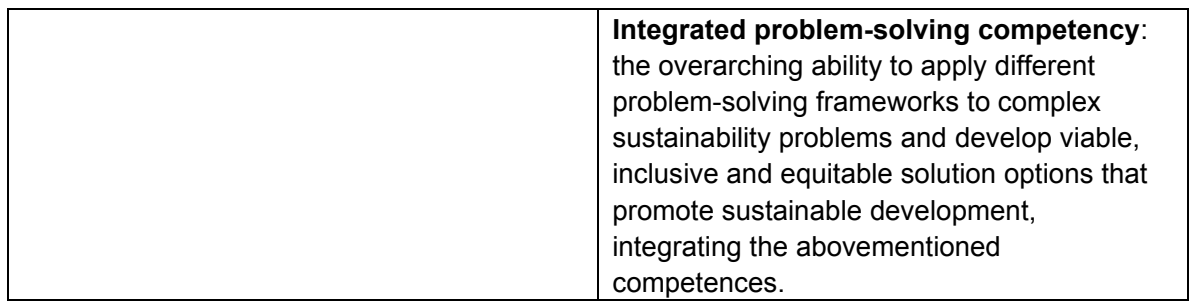

Wiek et al., 2011 and Wiek et al., 2016 competence frameworks contrasted with Rieckmann, 2018

The two conceptual frameworks above (Table 1) display obvious similarities in the selection and naming of competences. It is possible to see Rieckmann's (2018) framework, which is more recent, as more holistic and morally sensitive. The concept of competence can be understood as dualistic, individual, holistic, cultural, societal or relational. In the explanations of the competence aspects in Table 1, an ethical dimension stands out more clearly in Rieckmann (Rieckmann, 2018) than in Wiek et al. (Wiek et al., 2011; Wiek et al., 2016). The ethical notions of competence seem to receive further attention in the more recent framework.

Ethical competence with its critical approach, including analytical and normative dimensions, is in this thesis suggested to be recognized as a foundational part of ESD competence. A critical analysis of the concept of ethical competence was performed by Franck (2017), applying a philosophical perspective. Using Ben Kotzee's distinction between action-guidingness and world-guidedness (2011), ethics is related to the former and morals to the latter. Ethics is more universal in its attitude than morals, which boil down to the specific situation, related to the contingencies of a specific choice of action at a point in time and place. In her analysis of the Swedish curriculum for compulsory school (Skolverket, 2011), Karin Sporre analyses the space for global responsibilities and ethics in the introductory chapter of the Swedish national curriculum, as well as in the syllabi for the various school subject and in the national tests (Sporre, 2017). Rooted in human rights and democratic values, the outcome of the broad aims of the curriculum seems to correspond to a notion of ethical competence. Sporre (2017) points out that global responsibilities are addressed almost exclusively in the introductory part of the Swedish curriculum and not in the syllabi of the various school subjects. The overall aims of the national curriculum are that students should be able to formulate and express an ethical stance moored in knowledge, the values of democracy and human rights, and personal experience. Furthermore, students 
should develop a capacity to empathize with other people and prepare for action with the intention of promoting the well-being of others; they should also display critical thinking and independence when adopting a stance. Sporre's conclusion is that ethics is an interdisciplinary concept, and therefore requires an interdisciplinary orchestration of education.

\section{'Teachers' ESD competences}

There is an expectation that schools and teachers should offer an education that will awaken young people's interest in developing a sustainable society (Andersson, Jagers, Lindskog, \& Martinsson, 2013; Madsen, 2013). This increases the demands on the development of relevant ESD teacher competences (Bertschy, Künzli \& Lehmann, 2013; Bürgener \& Barth, 2018; Varga et al., 2007; UNECE, 2011). This expectation is hindered by at least two critical drawbacks, one of which concerns the lack of conceptual clarity regarding education for sustainable development (Borg, Gericke, Höglund, \& Bergman, 2012). This leads to the other concern, namely that the practical implications of sustainability-related education are not clear for the educators who are invited to adopt them (Dahl, 2019; Madsen, 2013). Both these forms of knowledge - what to teach and how to teach it - make up the teachers' professional action competency. These competences are fundamental pedagogical issues, in addition to the question of how to approach the development of competences and the question of appropriate learning settings (Bertschy, Künzli, \& Lehmann, 2013).

There are several lists of competences in the literature and models of competences that a teacher of ESD requires, for example Curriculum, Sustainable Development, Competences and Teacher Training (CSCT) and Competences in Education for Sustainable Development (ECE). Several competence frameworks and models have their origin in the OECD framework for competences in the DeSeCo project (Cebrián \& Junyent, 2015; Mochizuki \& Fadeeva, 2010; Rychen \& Salganik, 2003). The DeSeCo project aimed to develop more general competences for education based on workforce drivers on the one hand and broad social aspects on the other hand (Knain, 2005). With the purpose of approaching a globalized and rapidly changing world, the DeSeCo framework attempts to fathom the whole complexity of a holistic conceptualization of competence for lifelong living. 
A criticism raised regarding lists and frameworks of teacher competences is that they are conceived to be too general or difficult to use for in-service teachers (Bertschy et al., 2013; Varga et al., 2007). For that reason, Bertschy et al. (2013) suggest a model based on professional action competence. The concept is described as an interaction of knowledge, competence in a narrow conceptualization, and motivational, values, and conviction-oriented and selfregulating components.

At the end of the DESD, the United Nations Economic Commission for Europe (UNECE) published a report about teachers' ESD competences (UNECE, 2011, 2012). It consists of a model made up of four categories of competence, which mirror the four competence categories in the Delors Report (UNESCO, 1996). The four categories are:

- Learning to know refers to understanding the challenges facing society both locally and globally and the potential role of educators and learners (The educator understands....)

- Learning to do refers to developing practical skills and action competence in relation to education for sustainable development (The educator is able to....)

- Learning to live together contributes to the development of partnerships and an appreciation of interdependence, pluralism, mutual understanding and peace (The educator works with others in ways that...)

- Learning to be addresses the development of one's personal attributes and ability to act with greater autonomy, judgement and personal responsibility in relation to sustainable development (The educator is someone who....). (UNECE, 2011).

Each dimension is described using aspects of central characteristics of ESD:

- 'A holistic approach, which seeks integrative thinking and practice

- Envisioning change, which explores alternative futures, learns from the past and inspires engagement in the present; and

- Achieving transformation, which serves to change in the way people learn and in the systems that support learning.' (UNECE, 2011)

It is interesting to compare the definitions of teacher competences in ESD with the typology of environmental education traditions in Sweden (Östman \& Öhman, 2008; Skolverket, 2002). Based on contemporary environmental discussions, national and international environmental research, and dominant philosophical strands in education during the latter part of the twentieth century, three teaching traditions in environmental education were identified: the fact-based, the normative, and the pluralistic. The aims of the three traditions vary in so far as the fact-based tradition aims at developing students' knowledge of environmental problems. In the normative tradition, it is 
presented as relevant to emphasize the moral character of the environmental problems. The ethical position of the students, based on informed argumentation, is seen as the outcome of such education. The third tradition aims at developing students' competences to critically approach environmental problems and consider various options in a democratic and participatory manner. Recently, Öhman \& Östman (2019) elaborated on the three selective teaching traditions in the context of environmental and sustainability education. The traditions were discussed in relation to their approaches to sustainability challenges, didactic and democratic, as well as values-related issues. In addition, Sund and Gericke (2021) concluded in their review of the selective teaching traditions that the framework has provided a useful approach to exploring the purpose of environmental and sustainability education, student participation and democratic underpinnings in ESD. In my interpretation, these traditions epistemologically correspond to purely epistemic, purely moral, and a combined epistemico-ethical approach to the issues of sustainability, which means that they can be related to epistemic and ethical teacher considerations in ESD.

\section{Ethical competence}

In a review article on ethical competence, Osbeck, Franck, Lilja, and Sporre (2018) applied James Rest's framework to the analysed research articles and let an already existing concept enrich the development of categories in their analysis. To follow their example, Rest's framework (from Osbeck, Franck, Lilja \& Sporre, 2018) is juxtaposed in Table 2 with Nancy Tuana's framework of moral literacy (Tuana, 2007) and Östman and Öhman (2008). The three frameworks are juxtaposed and contrasted, thereby enriching each other in the process. Rest's processes clearly follow a linear procedure or perhaps development of actions, from perception/conception/awareness to evaluation/judgement, which provides the basis for motivation, and finally action. In contrast, Tuana's tripartite framework of moral literacy to some extent takes a dimensional and systemic approach, in that all three components are required for moral literacy to come into being. Each component provides significant aspects of ethical competence. The first one is ethics sensitivity, the ability to recognize the ethical issues in the situation. The second one involves ethical reasoning skills, which seem to relate to ethical knowledge, facts, and values relevant to the situation. Finally, the third component, moral reasoning, is made up of affective as well as rational processes. In one way, one could 
understand Tuana's components as processes, where the first one means that you become aware of the ethical dimension, the normative requirement necessary as a response to a situation; the second. a communicative dimension, as found in the Swedish curricula (Franck, 2017; Sporre, 2017). Finally, the third one, moral imagination involves other dimensions such as alternative scenarios. Reasons for action can in this way be addressed both emotionally and rationally, based on personal and social values.

The ethical tendency in education for sustainable development was pointed out in classroom studies that identified manifestations of the ethical tendency in specific situations (Öhman \& Östman, 2008). The authors established three situations that accommodated the ethical tendency: moral reactions, norms for correct behaviour, and ethical reflections. Moral reactions were conceived as personal, relativistic, and not related to knowledge. They seem to concern what the individual believes ought to be done, based on personal ideas and values. By contrast, norms for correct behaviour seem to relate to what we collectively and socially know we should do (Öhman \& Östman, 2008). Our actions are connected to social conventions and what we need to do to meet the expectations of our fellow beings. These actions need to be evaluated in relation to the shared rules for how we should treat other people. In ethical reflections, the ethical tendency concerns ethical principles. Insights should be applicable to general and universal situations, with less concern for the circumstances (Öhman \& Östman, 2008).

The three frameworks in Table 2 comprise similar components: the sensing of the ethical situation, the moral discussion and action or implementation.

Table 2 Dimensions and processes referring to ethical competence

\begin{tabular}{|l|l|l|l|l|}
\hline $\begin{array}{l}\text { Author/s \& } \\
\text { frameworks }\end{array}$ & \multicolumn{4}{|l|}{ Dimensions and processes } \\
\hline Rest (1986) & $\begin{array}{l}\text { moral } \\
\text { sensitivity }\end{array}$ & $\begin{array}{l}\text { moral } \\
\text { judgement }\end{array}$ & $\begin{array}{l}\text { moral } \\
\text { motivation }\end{array}$ & $\begin{array}{l}\text { moral } \\
\text { implementation }\end{array}$ \\
\hline Tuana (2007) & $\begin{array}{l}\text { ethics } \\
\text { sensitivity }\end{array}$ & $\begin{array}{l}\text { ethical } \\
\text { reasoning }\end{array}$ & $\begin{array}{l}\text { moral } \\
\text { imagination }\end{array}$ & \\
\cline { 1 - 3 } $\begin{array}{l}\text { Öhman \& Östman } \\
(2008)\end{array}$ & $\begin{array}{l}\text { moral } \\
\text { reactions }\end{array}$ & $\begin{array}{l}\text { norms for } \\
\text { correct } \\
\text { behaviour }\end{array}$ & $\begin{array}{l}\text { ethical } \\
\text { reflections }\end{array}$ & \\
\hline
\end{tabular}

Öhman and Östman's (2008) framework deviates slightly from the others, which is not surprising as their model consists of manifested dimensions from an empirical study. Rest's and Tuana's models are theoretically developed, whereas Öhman and Östman's framework is empirically based. It might be 
possible to argue that the theoretically developed frameworks are related to ethical competence, whereas the empirically based framework is related to moral or even normative competence.

According to United Nations Educational, Scientific and Cultural Organization, ESD is about making it possible for students and citizens to meet various global challenges in a constructive and creative way and creating sustainable and resilient societies (UN, 2020; UNESCO, 2018). What seems to be required is transformative learning (Leal Filho, Raath, Lazzarini, Vargas, De Souza, Anholon et al., 2018; MacIntyre, Lotz-Sisitka, Wals, Vogel, \& Tassone, 2018; Sterling, 2014), conceived as competence-based, favouring instruction dominated by participation. In addition to participation, agency is focused on ESD (Bandura, 2018), as well as students' democratic action competence (Almers, 2013; Breiting \& Mogensen, 1999; Lundegård \& Caiman, 2019; Mogensen \& Schnack, 2010; Rudsberg \& Öhman, 2010).

In Danish research, the concept of action competence has been put forward as the most important aim of ESD (Jensen \& Schnack, 1997; Mogensen \& Schnack, 2010). Mogensen and Schnack introduced action competence as an educational ideal in line with the German concept of Bildung. As such, action competence seems to be beyond what is achievable, what can be acted out. In the action-competence context, Bildung takes on Jon Hellesnes's notion of emancipation through becoming a political subject (Mogensen \& Schnack, 2010). Action competence, as the educational outcome, was explored in an action-research study about how to establish a pluralistic approach to ESD (Persson, Lundegård, \& Wickman, 2011). They defined action competence as students' abilities to take part in democratic processes for sustainable development in a critical manner. The pluralistic approach, in their interpretation, is one that makes space for students' voices, their actioncompetence and decision-making development in a serious way.

\section{Ethical and action competence}

The concept of sustainable development is an ethically grounded concept (Michelsen, Adomßent, Martens, \& Von Hauff, 2016). Ethical (Burford et al., 2013) and political issues regarding the responsibility for present and future generations and global issues of justice (Sund, 2014) are important drivers. The initial UN Conference in Stockholm in 1972 on the Human Environment revealed the conflict between the rich northern hemisphere countries who were 
looking to protect the environment, and the less developed countries of the southern hemisphere that needed industrialization and social development. Thus, social visions and notions of justice can be found in sustainable development (Michelsen et al., 2016). Against the background of ecological crises, an anthropocentric approach was adopted. As sustainable development is based on ethical norms, in 1996 the German Advisory Council attempted to ground the concept as an ethics of responsibility, uniting wisdom and duty. Three ethical elements of sustainable development were recognized:

- Responsibility of humanity for its natural environment.

- Responsibility of humanity for its social world.

- Responsibility of humanity for itself. (Michelsen et al., 2016:13) The real challenge, according to Michelsen et al. (2016), is to adopt an ethical stance that can combine freedom with responsibility for nature and humanity.

The dimensions of competence, or competence aspects as they can also be referred to, can be studied individually, but should be understood in interaction (Rieckmann, 2012). Thus, such an integrative and holistic conceptualization is based on the abilities the individual brings to a specific task in a cultural context (Hager \& Beckett, 1995). Knowledge, capacity, abilities, motivation, and affections are properties of the individual that co-exist and are at play in this conceptualization.

The moral theory of exemplars introduced by virtue ethicist Linda Zagzebski $(2013$; 2017) can be introduced in relation to notions of ethical and action competence. She shares with Tuana (2007) an interest in the pedagogical role of moral theory. The ethical stance of moral exemplars (Zagzebski, 2017) is acquired and consistent. An exemplar is identified through practice. Motivated by some internal disposition, it is in the moral actions of goodness or kindness that the exemplar comes into being. From external perspectives, the exemplar needs to be admired for his or her actions and whenever observed, the good or kind actions need to be consistent across domains and time (Zagzebski, 2017). However, there are aspects of both Tuana's and Zagzebski's theories that can be criticized: action is not addressed in Tuana's framework, or in the case of Zagzebski, the admirer may be an evil person, and will admire someone who is a murderer.

Even in pluralistic ESD, there is the risk that someone will be very much against sustainable development, and will argue for this and blatantly behave in an unsustainable way (Öhman \& Öhman, 2013). The other problem in an educational context is that students only profess to be sustainable but have no 
intention of changing their behaviour in a significant way. A moral exemplar, by contrast, and according to Zagzebski's definition, will not refrain from doing what is the right thing to do. The aspect of commitment in relation to ESD and the concept of competence has recently gained attention (Öhman \& Sund, 2021).

\section{Summary of the literature review}

In summary, epistemic beliefs have been theoretically and empirically established as important in cognition, learning and motivation (Buehl \& Alexander, 2001; Muis et al., 2006). In the context of ESD transformative learning is called for. It has been identified as a level of learning by Sterling and by Illeris, in response to the concept of competence, as a different type of education. Both conceptualizations can connect to a broad conceptualization of competence. Supranational organizations have promoted the concept of competence and it has been adopted in a great many countries across the world. The reconstructing of values, norms and perspectives address both the type of learning that the students experience and the level of learning they require. If transformative learning is believed to take place on a meta level, it can affect how the development of ESD competencies such as systems-thinking, normative and interpersonal competences is understood. The research regarding the concept of competences is relevant to education for sustainable development, but further empirical support is needed for the operationalization of sustainability competencies and tools for measuring and evaluating educators' competencies (Cebrián, Junyent, \& Mulà, 2020). In the next chapter these issues will be addressed through theoretical discussions of personal epistemology, conceptions of competence, and transformative education for sustainable development. 


\section{Chapter 3. Theoretical orientations}

Various concepts and theoretical frameworks are addressed in this chapter. The theory of epistemic beliefs is necessary methodologically for the operationalization of the empirical concept, the construction of a new research instrument, and finally the interpretation of the results. Ultimately, it makes it possible to answer research question 1 (RQ1). Similarly, the theory of competence is used in the operationalization, instrumentation, and analysis of teachers' ESD competences. However, not only is the theory of competence used for observing and analysing the data from the second empirical study concerning research question 2 (RQ2), but it also generates and adds theoretical perspectives from existent theories of competence. The theory of competence contributes to answering research questions 2 (RQ2) and 3 (RQ3). The theories are united by their relevance to the field of education for sustainable development and transformative education and serve various purposes in the thesis.

\section{Epistemic beliefs and personal epistemology}

The theory of epistemic beliefs that is adopted in this research project belongs to the dimensional framework, according to which an individual's epistemic beliefs are seen to be made up of several independent beliefs, such as certainty, structure, and source of knowledge (Duell \& Schommer-Aikins, 2001). In the dimensional or multidimensional framework, personal epistemology is seen as made up of systems of beliefs (Greene, Azevedo, \& Torney-Purta, 2008). The systems consist of asynchronous dimensions, generally described as continua, which means that they span from one extreme, which is labelled naïve, to the other, labelled sophisticated. The independent beliefs develop asynchronously. By contrast, in developmental epistemic theory, epistemic beliefs are seen as unidimensional and develop simultaneously. In a multidimensional framework, attention is directed to what epistemic beliefs are and what they do, how they predict educational outcomes (Greene et al., 2008). Model development is important and issues regarding whether dimensions are domain general or domain specific are concerned. Schommer (1990) presented the first domain- 
general model in this conceptualization with the following proposed dimensions: simple knowledge (ranging from the belief that knowledge is best characterized as isolated bits and pieces to the belief that knowledge is best characterized as highly interrelated concepts), certain knowledge (ranging from the belief that knowledge is absolute and unchanging to the belief that knowledge is tentative and evolving), omniscient authority (ranging from the belief that knowledge is handed down by authority to the belief that knowledge is derived from reason), fixed ability (ranging from the belief that ability to learn is given at birth to the belief that ability to learn can be increased), and quick learning (ranging from the belief that learning is quick or does not happen at all to the belief that learning takes time and is gradual). The number of dimensions reported by Schommer seems to vary between four and five, which is something that has been criticized in the literature (Clarebout, Elen, Luyten, \& Bamps, 2001). A four-dimensional model of epistemic beliefs (simple knowledge, certain knowledge, quick learning, and fixed ability to learn) was assumed by Schommer, based on her previous empirical studies (e.g., Schommer, 1990). It has been suggested that the first three dimensions in Schommer's conceptualization belong to the nature of knowledge and the last two to the nature of learning (Bråten, 2010).

In their seminal review article, Hofer and Pintrich (1997) adopted a purely epistemological stance and argued against the inclusion of dimensions regarding learning, as they do not explicitly deal with the nature of knowledge and knowing. Based on most models in the literature, Hofer and Pintrich suggest that personal theories or epistemic beliefs can be represented by two general areas of the nature of knowledge and the nature of knowing, each comprising two dimensions. Thus, their suggested framework consists of four dimensions: the certainty of knowledge, the structure or simplicity of knowledge, the justification of knowledge, and the source of knowledge (Hofer \& Pintrich, 1997).

Elby (2009) disagrees with Hofer and Pintrich, and suggests that epistemological and pedagogical views should not be perceived as separable. Although Elby does not claim that the theory of epistemic beliefs necessarily involves dimensions of learning, he advises the field not to settle on the purely epistemological approach. Despite the disagreement as to whether learning dimensions should be included in the construct or not, the important thing is perhaps not to find a true or ideal framework. As the theory develops, parts of the field of personal epistemology have moved in the direction of a broader 
scope of the object of research. Rather than focusing on beliefs per se, aspects of practices and cognitive processes are included. Consequently, this field of research seems to replace the concept of personal epistemology with epistemic cognition (Greene, Cartiff \& Duke, 2018). Epistemic cognition is broader, in the sense that it concerns how individuals think about what they know, what knowledge is, and how they can use what they know (Greene, Sandoval, \& Bråten, 2016; Kitchener, 1983): in short, what knowledge is, how knowledge is acquired, and how it is used. In my interpretation, this is a way of zooming out from epistemic beliefs to incorporate further empirical data to base the models on, and depending on the research questions, this can be a way to go. In the present thesis, however, the empirical focus is narrower, on the beliefs held by students involved in a sustainability project on food. Focusing only on epistemic beliefs continues to be the approach in most studies, according to a recent review article (Greene, Cartiff, \& Duke, 2018).

A recurring notion around epistemic beliefs is that they follow a developmental curve, which is described as a continuum from naïve to sophisticated. This notion is sometimes introduced somewhat casually. Several authors (Elby, 2009; Elby \& Hammer, 2001) have taken a critical attitude to the notion of sophistication in the theory of epistemic beliefs concerning scientific knowledge. They claim, for instance, that it could be quite unsophisticated to adopt a tentative attitude to the scientific fact that the world is round and not flat. Their critical views on the assumption of sophistication in epistemic beliefs are noteworthy. The important conclusion to draw from this is that evaluating one epistemic belief over another, or levels of sophistication within an epistemic belief, should be approached with some care. In instruction, in an introductory course for a new subject, it might be beneficial to the student if he or she adopts a naïve attitude when treating well-structured domains (Spiro et al., 1996). By contrast, a sophisticated attitude can be helpful in a content domain that is illstructured and characterized by a great deal of complexity, noticeably by a great many interrelated concepts, and irregular and inconsistent information (Richter, 2011). This logic allows for another hypothesis, that the sophistication of a person's epistemic beliefs does not rest in the construct itself, but rather in the management of the process, which Maggioni and Parkinson would refer to as epistemic cognition (2008).

The number of dimensions seems to attract attention in many studies where Schommer's questionnaire is used. In the two most famous models, Schommer's and Hofer and Pintrich's, they seem to decide on four dimensions 
(Schommer \& Walker, 1995), although Schommer initially reported five on a theoretical basis (Schommer-Aikens, 2008). However, in the empirical study of students' epistemic beliefs in this thesis (Paper II), which is exploratory, the attitude to the number of dimensions is open.

The focus of the empirical study of students' epistemic beliefs (Paper II) in this doctoral thesis is on what these epistemic beliefs are and what impact they have, not how they develop. The research interest in this thesis is the dimensionality of epistemic beliefs among the participating students, and whether and how these beliefs impacted the students' learning experience.

\section{Transdisciplinary and transformative ESD}

Sustainable development issues are frequently referred to as wicked (Lönngren \& Van Poeck, 2020; Rittel \& Webber, 1973). This suggests that there are complexities and uncertainties when it comes to understanding the problem and to finding efficient solutions. The methods to solve the issues are not clearcut either. To deal with such complexities and wicked problems, the concept of competence can be an applicable one in education and professional development. To create a sustainable future and meet the complexity of sustainability challenges, expertise is required from more than one discipline. Thus, inter- and transdisciplinary approaches are recommended (Darbellay, 2015; Guimarães, Pohl, Bina, \& Varanda, 2019).

Two complementary orientations can be found in the concept of transdisciplinarity. The first one is of an epistemological nature and identifies transdisciplinarity as a process of knowing that moves beyond disciplinary boundaries and transforms the disciplinary divisions (Darbellay, 2015). The second approach is of a pragmatic nature, in which participation and applied transdisciplinarity provide a method that brings together the scientific community and various social and economic stakeholders, incorporating the ordinary citizen into the research process to find possible solutions to the problems (Darbellay, 2015). Supported by cross-curricular approaches, ESD issues are dealt with by considering environmental, social, and economic aspects (Björklund, 2014; Murphy, 2012; SOU 2004:104). Various models of integration and interdisciplinarity, and possibilities and challenges of multi-, inter- and transdisciplinarity in academia are reflected in the division of school subjects in upper-secondary school (Nordén, 2018). Despite the belief in transdisciplinarity 
as an educational ideal in the context of ESD, there are few empirical studies to support it (Nordén, 2018).

The dominant discourse on interdisciplinarity mainly focuses on how different disciplines contribute to a coherent framework. Recently, the analyses of transdisciplinarity have shifted the focus towards the joint co-production of knowledge by scientific and extra-scientific actors. The aim of transdisciplinarity is not to provide a common theoretical framework, but rather to foster self-reflection, openness to others, and a willingness to engage with others (Popa, Guillermin, \& Dedeurwaerdere, 2015) Its aim is to contribute to both societal and scientific progress, such as in the context of sustainability, where problems are characterized by uncertainties and value-conflicts which cannot be solved with prevalent technical-instrumental rationality. Consequently, the epistemic and the societal approaches provide an arena for ethics and ethical competence.

In the context of articulating the problem of unsustainable societies and the urgency of finding new solutions to the problems, transformation is called for. The necessary transformation of the individual, education, and society requires new ways of thinking and acting, and the development of new sets of competencies (Garcia, Junyent \& Fonolleda, 2017). Education for sustainable development has, an established link to quality education (Barth \& Michelsen, 2013; Breiting \& Mayer, 2014). This is made clear by the SDG 4, which is named Quality education. The main objective of SDG 4 is to provide education of good quality and to promote lifelong learning for all. Quality education is an evolving and often contested concept (Laurie, Nonoyama-Tarumi, McKeown, \& Hopkins, 2016), which according to UNESCO (UNESCO, 2004, in Laurie et al., 2016) seems possible to unify through two principles, namely the notion that the main objective of all education is to develop learners' cognition, and that the role of education role is to promote values and attitudes connected to responsible citizenship and to provide creative and emotional development opportunities. These principles can be perceived as two bidirectional forces that occur theoretically between the need for social change towards sustainability and the necessary freedom and openness of educational processes. If ESD is perceived partially as an arena for action competence (Breiting \& Mogensen, 1999; Mogensen \& Schnack, 2010; Vare \& Scott, 2007) and partially as a political arena (Öhman, 2008), political self-efficacy seems to be relevant to the agency students are supposed to develop. The latter, however, is not in focus in this thesis, although it is certainly relevant to further research (Sohl, 2014). 
The United Nations Decade of Education for Sustainable Development (UNDESD) 2005-2014 transmitted a vision of sustainability as social learning. The purpose was to rethink and redesign education at all levels with a clear focus on the development of knowledge, skills, perspectives, and values relevant to sustainability (UNESCO, 2006; Vare \& Scott, 2007). It is possible to see how a broad or extended conception of competence can accommodate the complexity of such educational outcomes. The whole educational system was challenged into developing transdisciplinary approaches and understandings of the dimensions of sustainable development, frequently referred to as the three pillars of ESD: ecology, economy, and society. Following this decade, in 2015 the UN adopted the 17 Sustainable Development Goals, which were presented in Transforming our World (UN General Assembly, 2015). With UNESCO's Global Action Programme (20152019), the urgency of change and transformation of learning and society and the empowering of youth are highlighted. In Agenda 2030, the plan of action is scaled up with 17 goals (SDGs) and 169 targets (UN General Assembly, 2015). They are all integrated and there is a specific goal for education, SDG 4. Both these agendas call for action and new knowledge. The pedagogical characteristics of ESD are that it is holistic and transformative in its critical approach to what students should learn.

\section{The competence-driven curriculum}

Competence-based approaches have been promoted by the United Nations Educational, Scientific and Cultural Organisation (UNESCO), the Organisation for Economic Co-operation and Development (OECD), and the European Union (EU), which has led to significant epistemological restructuring of a great many countries' curricula (Nordin \& Sundberg, 2021; Wiek et al., 2016). UNESCO has played a pivotal role in reintroducing the concept of competence in curriculum studies, through the Delors Report, Learning: The Treasure Within (UNESCO, 1996). It delineates a framework of four pillars: learning to know, learning to do, learning to live together, and learning to be. The way the ideas of competences are expressed in frameworks related to the organizations above has had a nearly global impact on how curricular knowledge is developed, conceptualized, implemented, and assessed (Nordin \& Sundberg, 2021). Although the emergence of competence-based education (CBE) is fairly recent, the concept of competence is not new in the field of education and curriculum 
studies. In relation to the content of ESD and the concept of competence, it seems relevant to ask what possibilities the concept of competence in the curriculum can offer, and what the limitations of the concept might be. The concept is not without its critics. There are at least two reasons why the use of concept of competence has been met with reluctance (Hager \& Gonczi, 1996). One reason for this may be that a narrow conceptualization of the concept of competence leads to a perception that competence is related in an instrumental way to performance and behaviour. In the assessment of such competence, a check-list can be used to tick off the various tasks that should be performed, corresponding to a simplistic understanding of the knowledge required of a person. In the assessment of such competence, a check-list can be used to tick off the various tasks that should be performed can be seen as a simplistic understanding of the knowledge required of a person, as it corresponds to behaviour only (Hager \& Gonczi, 1996). Secondly, this narrow conceptualization also fails to capture the potential of the complexity of human capabilities and sidesteps integrated competence aspects such as knowledge and understanding (Lum, 2013). As a response to this, an integrated conceptualization is advocated by authors who see the potential of the concept of competence in education. The integrated conceptualization is multidimensional and comprises several competence aspects such as knowledge, skills, attitudes, values (Lum, 2013).

In Sweden, the most recent curriculum reform of 2011 (slightly revised in 2018 ) is based on a reconfiguration of the notion of competence that was reintroduced in the 1990s (Nordin \& Sundberg, 2021). The CBE curriculum is a global phenomenon with various adaptations to local contexts. The definitions of the concept of competence seem to converge in notions of collaboration, communication, creativity, critical thinking, problem-solving, ICT literacy, and social/cultural skills (Nordin \& Sundberg, 2021). Worldwide, $\mathrm{CBE}$ is looked upon as innovative in its aim to achieve superior performance in addition to combining the world of work and the world of education to satisfy labour market requirements and necessary development in society (Mulder \& Winterton, 2016). A definition of CBE based on a recent literature review and key-informant interviews is that $\mathrm{CBE}$ is an outcome-based approach to education that incorporates modes of instructional delivery and assessment efforts designed to evaluate mastery of learning by students through their demonstration of the knowledge, attitudes, values, skills, and behaviours 
required for the degree sought (Gervais, 2013). The European Commission argues for $\mathrm{CBE}$ in the following way:

Competence-oriented education is regarded as advantageous in a time when the knowledge base of our societies is developing at an immense speed and when the skills required need to be transferred to and developed in many different societal contexts, including those unforeseen in the future (European Commission, 2018).

In response to the concept of competence, a theory of transformative learning was developed by Knud Illeris (Illeris, 2004). Based on the work of Piaget and the Danish psychologist Thomas Nissen, Illeris identifies four learning types in his theory. The first one is cumulation, which is an acquisition of knowledge that is mechanical, and a recall of that knowledge can be made in situations similar to the ones where the knowledge was acquired. The second and third learning types are Piaget's assimilation and accommodation, where the first is learning by adding knowledge to already existing schemes, whereas the second requires analysis and restructuring of the schema to be able to incorporate the new knowledge. A fourth category is suggested by Illeris: transformation. This is a type of knowledge development that impacts on and even changes the knower's personality. It involves a restructuring of all dimensions of learning: the cognitive, the emotional and the social dimensions. The cognitive dimension corresponds to the learner's construction of meaning and ability to meet various challenges. The social dimension relates to how the learner integrates with communities and society. The emotional dimension refers to how the learner balances mental energy, feeling, and motivations. All three can be understood as tension fields of learning. Knowledge, abilities, and emotions express functionality, sociality, and sensitivity, which make up the fundamental elements of the concept of competence (Illeris, 2004). At the core of such a broad conceptualization of competence rests the ability to handle uncertainties and the unpredictable. Transformative learning was not originally connected to mega-problems of society, such as climate change and sustainable development. It was a mode of change in perception and meaning making that was first identified by Mezirow in adult education, which meant that the student or learner becomes critical of his or her assumptions and habits of thought, to the extent that he or she reframes them (Sterling, 2011). As pointed out by Illeris (2004), it is not clear whether Mezirow's notion of transformative learning is in fact accommodation or whether it includes all of the three dimensions of 
learning, and could be considered genuine transformation. What Illeris refers to as genuine transformation means that all three dimensions of learning, the cognitive, the emotional, and the social, are restructured simultaneously.

Illeris' theory of transformative learning captures the types of learning involved, whereas in Sterling's (2011) conceptualization, transformation is a matter of level, which Table 3 shows.

Table 3 Levels of change and learning

\begin{tabular}{|l|l|l|}
\hline $\begin{array}{l}\text { Orders of } \\
\text { change/learnings }\end{array}$ & Seeks/leads to & Can be labelled as \\
\hline $\begin{array}{l}\text { First-order change } \\
\text { cognition }\end{array}$ & Effectiveness/efficiency & $\begin{array}{l}\text { 'Doing things better'. } \\
\text { Conformative }\end{array}$ \\
\hline $\begin{array}{l}\text { Second-order change } \\
\text { meta-cognition }\end{array}$ & $\begin{array}{l}\text { Examining and changing } \\
\text { assumptions }\end{array}$ & $\begin{array}{l}\text { 'Doing things better'. } \\
\text { Reformative }\end{array}$ \\
\hline $\begin{array}{l}\text { Third-order change } \\
\text { epistemic learning }\end{array}$ & Paradigm change & $\begin{array}{l}\text { 'Seeing things better'. } \\
\text { Transformative }\end{array}$ \\
\hline
\end{tabular}

Sterling's (2011) levels of change and learning.

In their review article, which examined to what extent transformative learning has been conceptualized and operationalized in ESD Aboytes and Barth (2020) further explored the connection between transformative learning and education for sustainability. Based on the empirical contexts of sustainability learning research, they conclude that social learning, experience, and the development of sustainability competencies are inherently connected in transformative learning. The learning process and outcomes in the articles that used transformative learning as the central theory are described as (Aboytes \& Barth, 2020):

- Increase of new knowledge and practical skills

- Reconstruction of values, norms and perspectives

- Increase in the sense of, self-awareness, agency and empowerment

- Development of critical, systems and complex thinking

- Social learning (reinforcement of social relationships, social mobilisation and activism) (Aboytes \& Barth, 2020)

As ESD seeks to empower individuals by being critical of unsustainable practices, and business-as-usual values and norms, highlighting sustainable principles and ethics makes the approach robust (Aboytes \& Barth, 2020). By 
reconstructing their values, norms and perspectives, students are thought to become empathetic and compassionate, to recognize collective concerns, and to aim for safe environmental resources and social justice. A sense of unity and interrelatedness with their natural and social surroundings can thus be achieved (Aboytes \& Barth, 2020). If transformative learning is conceptualized as a metatheory, it can provide insights into the development of various ESD competencies, such as systems-thinking competencies, and normative and interpersonal competencies (Wiek, Withycombe, \& Redman, 2011). However, there is a risk that all learning is referred to as transformative, which will harm the clarity of the concept. 


\section{Chapter 4. Research design and methodology}

The basic intent of this chapter is to provide an overview of the methods applied in the present research project. The thesis attempts to explore the dimensionality of epistemic beliefs among Swedish upper-secondary students and sustainability competence among teachers, thereby extending the conceptions of competence relevant to addressing issues of sustainability in research, education, and practice. Analytically, the research questions fall into two categories, one empirical and one conceptual, with an emphasis on the broader theoretical issues. In a theoretical study, the aim is to construct understanding and knowledge which is applicable in practice. As this is educational science research, the aim is practical in at least two ways. The thesis aims to inform and be significant to educational practice, and it supports extended research methods that do not pay heed to the dichotomy between empiricism and theory (rationalism), and quantitative versus qualitative exclusionary approaches in research. The overall concern and approach of this thesis is philosophical. That means that the results from the empirical studies are reflected on and extended beyond the explication of the empirical results. The integrative research design offers several perspectives and allows for the juxtaposition of explanatory, exploratory, and explicatory findings.

The broad research aims of exploring epistemological issues in education for sustainable development account for the philosophical approach and the three theoretical studies of an emergent design that followed the initial survey study of students' epistemic beliefs. In a snowball fashion, the theoretical exploration of one concept led to another exploration of relevant concepts, all related to the educational context of the initial empirical study of students' epistemic beliefs. This research design resonates with what Alvesson and Sköldberg (2018) refer to as reflective methodology. They suggest that the reflective areas that should be involved in good research practice are empirical orientation, hermeneutics, critical theory, and postmodernism. They advocate a freer view of data-handling, and claim that empirical material should be inspirational for theories. Empirical material can have varying weight depending 
on the context and the degree to which it has been processed. Data, per se, will not prove anything. Alvesson and Sköldberg (2018) find empirical material important, but it should be acknowledged as an expression of negotiable, perspective-dependent interpretations. A mirror simile is used to exemplify what they mean. Empirical material is like a picture in a hall with concave and convex mirrors. Alvesson and Sköldberg (2018) find the results of quantitative studies to be weak. However, the basis for reflective methodology could arguably be various types of empirical work, and in this thesis, two empirical studies are integrated with theoretical studies.

Reflective methodology can furthermore be contrasted with reflexive methodology, where the research process is explicitly addressed as impacted by the researcher's personhood (Romm, 1998). Despite the awareness of the fact that sustainability can be operated in a non-inclusionary manner for people of different social fields, this is not the focus of the thesis. The researcher's background, knowledge, and literacy naturally have an impact on the research questions, choice of methods, results, and analyses, but in the present thesis those aspects, however relevant to other research questions and designs, are not brought into the analyses as such. The present research is perhaps best described as empirically oriented theoretical research with a practical aim, providing knowledge and understanding for educational practice to reflect on and to readdress in instruction, and providing a theoretical basis for further empirical studies on epistemic beliefs and competences in education for sustainable development.

\section{An emergent research design}

The purpose of this research project is to explore students' beliefs about knowledge and knowing in an educational context, as well as teachers' approaches to education for sustainable development, and to address relevant concepts that evolve out of the various analyses. Despite the fact that there is some convergence among researchers regarding the theory about epistemic beliefs, here the aim is not to confirm a specific model but to examine what dimensions surface among students involved in a transdisciplinary educational project regarding sustainable development. The research approach in this thesis is exploratory and pragmatic, as well as emergent and abductive. This means that it is the process of conducting research that makes the research design reach across empirical and theoretical methods. For pedagogical reasons, I 
contrast the studies as empirical versus theoretical, but I do not conceive of the theoretical studies as non-empirical. It is an issue of how data is gathered or incorporated into the analysis. As epistemology is in focus in the empirical study of students' epistemic beliefs and as the aim is to explore the dimensionality of their epistemic beliefs, it became relevant in the research process to explore conceptualizations of knowledge in the curriculum and to approach the concept of ESD from a philosophical perspective.

The research design evolves across multiple methods, statistical, interpretative, and heuristic, when the object of study moves between ESD as the research site for the empirical study of students' epistemic beliefs, and an inquiry into how differently the four syllabi for the social science subjects in the Swedish curriculum for compulsory education address ESD. It is the concept of ESD that is the object of knowledge, not the case of specific uppersecondary school students. To clarify, the variability of the interpretations of ESD was explored in four syllabi that might be expected to share similar interpretations. The varied interpretations of ESD in four related syllabi lead the research outline to approach notions of competence, epistemic and ethical. A further line of inquiry follows logically, namely in-service teachers implementing ESD at a specific school. The broad research aims of exploring epistemological and ethical conceptualizations in education for sustainable development explain the philosophical methodological approach and the theoretical studies, which can be identified as extended empirical studies.

The overall exploratory and emergent research design (Given, 2008) of the doctoral thesis uses parallel but for the most part sequential phases of empirical and theoretical (pre- and post-empirical ${ }^{4}$ ) studies which is illustrated by Figure 1 below.

\footnotetext{
4 A tentative concept to methodologically illustrate the relationship to the empirical studies.
} 


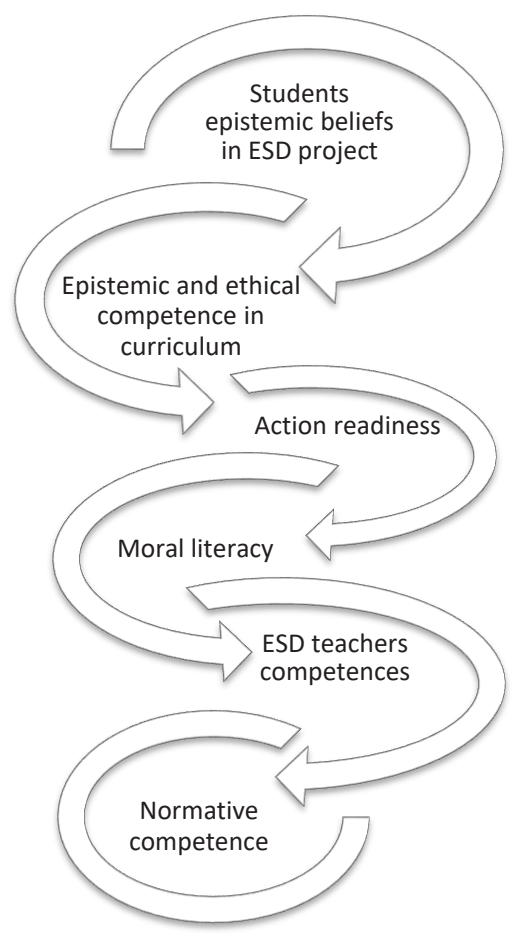

Figure 1 Illustration of the exploratory and emergent research design

A characteristic element of this design is that it is research-process driven and sensitive to the results from previous empirical or theoretical studies within the research project (Given, 2008). It aims to study or describe the research problem in extended ways in relation to the field of ESD. Such a design allows for an empirical study of students' epistemic beliefs to lead to parallel or sequential theoretical studies based on the empirical results. The basis for the conceptual studies or the problem areas are not pre-defined in this project, but emerge from the research process, the problem field, the object of study with its content and methods, or the results. One way of describing the emergent design, as previously mentioned, is to compare it to a snowball-sampling method (Cresswell, 2007). The theoretical exploration of one concept leads to new issues regarding another emanating concept, all related to the educational context of the initial empirical study of students' epistemic beliefs. Instead of having one interviewee recommending another interviewee as a method of selection in a study, here, one conceptual analysis gives rise to another. This design evolves through the results from each empirical or theoretical study and 
motivates further exploration and analysis, which can be compared to what Alvesson and Sköldberg (2018) refer to as reflective methodology. Here, the combination of empirical and theoretical research through empirical as well as interpretative studies are assumed to be in line with reflective methodology. This means that the standpoint is pragmatic and transmethodological ${ }^{5}$ and refutes a dichotomous positioning of the empirical and theoretical, or quantitative and qualitative paradigms (Cameron, 2009). There are philosophical as well as pragmatic reasons for this choice of methodology. The reason for the philosophical approach is an inclination to be able to go beyond the empirical results and achieve new knowledge through reflection, while remaining moored in empirical exploration with the intent of providing valuable results for educational practice. Empirical considerations are certainly relevant to philosophical questions. However, this does not suggest that the empirical methods will wholly capture the research questions (Barth, 2013). The present thesis is made up of four theoretical (Papers I, III, IV and VI) and two empirical studies (Papers II and V).

As pointed out previously, the combined methods allow for extended results of various kinds: explanatory, exploratory, and explicatory. The statistical analyses make it possible to explain a causal relationship between various variables. Through multiple regression analysis, it is possible to explain how the variables from the factor analysis and the background variables impact the dependent variable. The approach is exploratory, as the aim is not to find a specific model of epistemic beliefs, but rather to explore what they are and how they operate in different contexts. Explication is a concept that goes beyond explanation, in that it reveals the nature of the concept without establishing a final and explicit definition (Blackburn, 2016). Through conceptual analysis and the application of philosophizing with, explicatory results are constructed. Exploratory research is here appreciated as an approach that is open to new knowledge. There are no hypotheses, and the data analysis does not consist in confirming a specific model. According to Ponce \& Pagán-Maldonado (2015), the validity of the research product is evaluated on the relevance of the data analysis and the correspondence between the data collected and interpretations made by the researcher of this information.

\footnotetext{
${ }^{5}$ A tentative concept for this methodology, suggested by the author.
} 


\section{Statistical analyses}

The statistical analyses employed in the two empirical studies (Papers II and V) are correlation and regression analyses. The analyses were carried out in SPSS versions 21 and 23 respectively. SPSS is an abbreviation for statistical package for the social sciences. Statistical analysis is a programme that makes it possible to perform statistical analyses of the two empirical concepts, epistemic beliefs and teachers' ESD competence. The statistical analyses disregard various social contexts and could, depending on the aim of the study and the research questions, be seen to have limited powers and resources. However, in the case of exploring the dimensionality of epistemic beliefs and teachers' competences in the context of ESD in a multimethodological design, correlation and regression analyses are choices of method that meet what is required by the research questions.

This section of the thesis describes broadly factor analysis and multiple regression analysis, addresses notions of validity and reliability, the theory of which is vital for operationalizing the empirical concepts into research instruments. Further statistical tests can be found in Papers II and V in Part 2 of the thesis.

Factor analysis builds on the assumption that there are observable variables, and latent and not observable variables (Barmark, 2009). The items in the questionnaire make up the observable variables, but it is assumed that there are some latent constructs that impact the observed variables. The latent variables are explanatory in relation to the manifested or observed variables. It is assumed in factor analysis that the latent factors affect the various items or variables in the questionnaire. A few latent variables can account for a great many individual variables. In this respect, the factor analysis also summarizes the observed variables and establishes categories of variables that covary.

The variables that make up each factor have some resemblance, which is manifested in the latent theoretical construct or factor. Thus, a factor analysis is an empirically-driven process that serves to develop the theoretical understanding of the data (Barmark, 2009, p. 72). An exploratory factor analysis (EFA) is a tentative approach by the researcher and requires an openness to the final model. Barmark (2009) points out that despite the sensitivity to the data, a factor analysis relies on a sound theoretical understanding that can guide the exploratory approach, which entails iterations of testing before the final model is established. 
In both empirical studies, factor analysis was applied with orthogonal Varimax rotation and an eigenvalue greater than one as a cut-off point, and a principal factoring extraction generated a number of factors. The final number of factors was established on empirical as well as theoretical grounds. The factor loading varies from -1 to 1 , and the closer the factors are to the two endpoints, the more they affect the items. Items from the questionnaire that are affected by an individual factor should have factor loadings of 0.4 of higher. The interpretation of factors is based on those variables that are highly correlated with them.

Multiple regression analysis (MRA) is a statistical method that can be used to explain how various independent variables predict a dependent variable. Regression analysis allows for several predictor variables (multiple regression) to an outcome variable. The analysis makes it possible to go a step beyond the data that was gathered. In this thesis, multiple regression analysis was employed to understand how the various factors or dimensions of students' epistemic beliefs (Paper II), controlling for age, gender, and study programme, impacted the students' orientation towards a transdisciplinary sustainability educational project. Based on the EFA and the background variables: study programme, sex, and age, independent variables were constructed: index variables and dummy variables.

\section{Instrumentation}

Typically, epistemic beliefs have been studied using various research instruments (Mason, Boscolo, Tornatora, Ronconi, 2013). I designed two new research instruments for the two empirical studies in this thesis: the Survey of Epistemological Beliefs in Transdisciplinary Education, abbreviated SEBTE (Paper II), and Teachers' Education for Sustainable Development Competences, abbreviated TESDC (Paper V). The first one, SEBTE, sought to explore the domain-general epistemic beliefs among upper-secondary students involved in a sustainable educational project about food. The second, TESDC, examined teacher competences displayed by in-service teachers at a large uppersecondary school implementing ESD (Paper V).

Following Hofer and Pintrich's (1997) conceptualization, SEBTE takes a philosophical stance on epistemic beliefs, and the assumed dimensions are the structure of knowledge, the source of knowledge, and the justification of knowledge. In Hofer and Pintrich (1997), the simplicity of knowledge and the certainty of knowledge 
are identified as separate dimensions. In SEBTE, they are assumed to fall within one and the same dimension, namely the structure of knowledge. Another assumption in the development of the instrument is that epistemic beliefs are domain-general but to some extent depend on or interact with the context. Although they are assumed to be domain-general, the epistemic beliefs prevalent among the participants in the current study are contextualized in education for sustainable development. The learning content and the organization of education will be considered when interpreting the rendered dimensions of epistemic beliefs.

Items from three existing domain-general instruments were used to develop the questionnaire: Schommer's Epistemological Questionnaire (1990), Schraw et al.'s. Epistemic Beliefs Inventory (Schraw, Bendixen, \& Dunkle, 2002), and Wood and Kardash's Epistemological Beliefs Survey (2002). The instruments were all retrieved from DeBacker, Crowson, Beesley, Thoma, \& Hestevold (2008). Fourteen items from Schommer's EQ were included in SEBTE, five of which had also been repeated by Schraw et al. (2002). An additional three items were used from Wood and Kardash. See Table 4 below. All these items had been previously validated. The items were translated into Swedish and only slightly modernized as far as the wording was concerned. Repeating valid items makes the instrument robust. Additional items were added to explore the transdisciplinary approach (Paper II). A six-point Likert scale with the end points, No, not all to Yes, absolutely was used. See Appendix A for all items in Swedish.

Table 4 Repeated and new items in SEBTE

\begin{tabular}{|c|c|c|c|}
\hline $\begin{array}{l}\text { Schommer } \\
\text { (1990) EQ }\end{array}$ & $\begin{array}{l}\text { Schraw et al. } \\
(2002) \text { EBI }\end{array}$ & $\begin{array}{l}\text { Wood \& Kardash } \\
\text { (2002) EBS }\end{array}$ & $\begin{array}{l}\text { Grice } \\
\text { (2014) SEBTE }\end{array}$ \\
\hline $\begin{array}{l}\text { No. } 1,3,9,11,13,14 \\
15,16,17,18,19,23 \\
25,26\end{array}$ & $\begin{array}{l}\text { No. } 1,3,9,15,18 \text {, } \\
20,25\end{array}$ & $\begin{array}{l}\text { No. } 5,10,11,13,15 \text {, } \\
16,18,20,26\end{array}$ & $\begin{array}{l}\text { No. } 2,4,6,7,8,12 \text {, } \\
21,22,24\end{array}$ \\
\hline
\end{tabular}

Items were repeated from three previous instruments and a new set of items were introduced by SEBTE.

By contrast, TESDC is an entirely new instrument, as a research instrument that quantitatively explored teachers' ESD competence could not be found. See Appendix B for the Swedish, original version. Consequently, there were no valid items to repeat from the literature. Instead, the theory of various conceptualizations of competence were used to construct the instrument. The theory about the competences that students are assumed to develop in ESD, 
the pedagogy that in the literature is described as student- and experiencecentred, active, participatory, transdisciplinary and ethical, together with results from studies that have focused on teachers' understanding and approaches to ESD (Borg, Gericke, Höglund, \& Bergman, 2012; Rauch \& Steiner, 2013) were used. Several competence models have their origin in OECD's DeSeCo project (Cebrián \& Junyent, 2015; Knain, 2005; Mochizuki \& Fadeeva, 2010; Rychen \& Salganik, 2003). It is a holistic and integrative conceptualization of competence that aims to fathom the whole complexity of the concept. The assumed competence aspects in the TESDC instrument are knowledge (6 items, relates to the cognitive sphere and conceptual knowledge), practical ability (7 items, relates to procedural, general work, and problem-solution skills, including skills of communication, social change, and action competence; procedures, methods, strategies, tools and techniques beyond knowledge), ethical values (7 items, relate to normative principles that rule human behaviour in a specific situation; how humans think that they ought to interact with other people in society, and with nature), attitudes (4 items, relate to the tendency to act in a particular way in relation to specific stimuli, in external and internal situations, e.g. adopt the attitude of valuing others, dialogue, participation and cooperation) and emotions ( 2 items, relate to self-awareness and self-knowledge, feelings and emotions that rule us). This framework was used in the empirical analysis of student teachers by Cebrián and Junyent (2015) and is based on the DeSeCo framework. DeSeCo defines competence broadly as something more than just knowledge and skills. It involves the ability to meet complex demands, by drawing on and mobilising psychosocial resources (including skills and attitudes) in a particular context. (OECD, 2005). See Appendix B for all items in Swedish.

\section{Empirical study of students' epistemic beliefs}

In the empirical study of students' epistemic beliefs (reported in Paper II), 208 students from 16 different schools participated. Epistemic beliefs were empirically explored among 208 students participating in a transdisciplinary educational project regarding food. Students from 16 different schools, teachers, and extramural experts were involved. The students' educational programmes were divided into three categories: socio-economic, technical-scientific and other. 56 per cent of the students were female, 37 per cent male and 7 per cent did not state their gender. For four months, the students worked individually or in small groups together with their teachers, but also with access 
to 39 external experts in various fields. They held positions for example at the University of Gothenburg, the Swedish University of Agricultural Sciences, Sweden's government agency for development cooperation (SIDA), Greenpeace, and The Federation of Swedish Farmers. In the sense that a theme is taught across the curriculum, transdisciplinary education can sometimes be interchangeable with interdisciplinary education, which is rather an attempt to teach across school subjects. The assumption is that both the content and the way education is organized will prove complex and offer contradictory knowledge to some extent. A concern in the educational project Our Food was how students would orient themselves in such an educational setting.

Data was collected through the administration of the questionnaire SEBTE, a paper-and-pencil, self-completion questionnaire. Several attempts to conceptualize epistemic thinking as a set of independent beliefs (Hofer, 2000; Schommer, 1990; Schraw, Bendixen \& Dunkle, 2002) have used a pen-andpaper questionnaire (Barzilai \& Weinstock, 2015). The SEBTE unique items that had not been used in the previous three instruments where the rest of the items were collected, added a transdisciplinary aspect to the conceptualization of knowledge and knowing. The educational project was also evaluated through five variables specific to the educational project: B1. Have you been able to use knowledge from more than one school subjects in your project? B2. Has the project given you knowledge about the possibility of sustainable development in society? B3. Will you be able to use what you have learned in the project for other courses in your upper-secondary educational programme? B4. Has the project aroused new interests or ideas for future studies or work? B5. Has the project been meaningful? The educational project was transdisciplinary in the sense that the physical boundaries of the school were transgressed and multiple stake-holders were invited. Students also physically left the school to find new knowledge and to meet the stakeholders and the co-authors of the book on food. The five items foreground sustainable development, transdisciplinarity, and ethical and epistemic issues.

\section{Empirical study of teachers' ESD competences}

In the empirical study of teacher competences in the context of ESD, reported in Paper V, 183 teachers participated. The TESDC instrument was administered digitally through a recently introduced survey tool at the school. The questionnaire was sent out at the beginning of the school year, three days before 
a professional development day about ESD. A reminder was sent out once. There were 358 teachers in total at the school. 51 per cent $(n=183)$ participated. 53 per cent were women, 46.5 per cent men, 0.5 per cent $\mathrm{n} / \mathrm{a}$. Most of the participants had been teaching for between 11 and 19 years and were in the age band 40 - 49 years old. The largest group of teachers participating were vocational teachers and teachers in aesthetics, followed by teachers of language, natural science, technology, and mathematics. See Table 5 below:

Table 5 Participants

\begin{tabular}{llllllll}
\hline Teaching subjects & N & Women & Per cent & Men & Per cent & n/a & Per cent \\
\hline $\begin{array}{l}\text { Natural science, mathematics, } \\
\text { technology, computer science }\end{array}$ & 34 & 14 & 41 & 20 & 59 & & \\
\hline Civics, geography & 19 & 12 & 63 & 7 & 37 & & \\
\hline Languages, Swedish & 36 & 28 & 78 & 7 & 19 & 1 & 3 \\
\hline Vocational, aesthetic & 74 & 30 & 40 & 44 & 60 & & \\
\hline Other, several & 20 & 13 & 65 & 7 & 35 & & \\
\hline Total & 183 & 97 & 53,0 & 85 & 46,5 & 1 & 0,5 \\
\hline
\end{tabular}

Number of participants, their teaching subjects, gender within each subject category and total gender distribution.

As the empirical site for this study, one of Sweden's largest upper-secondary school was selected. The school has been aiming to implement ESD through annual professional development at teacher professional development days, and the municipality has had an environmental management system for more than ten years. The implementation was supported by the Global School, a branch of the Swedish Council for Higher Education, a government agency whose responsibility spans the whole education sector ${ }^{6}$. The authors of the article (Paper V) took an active role in the implementation. The lead author was a researching teacher at the upper-secondary school. The other authors represented the Global School, the municipality of Uddevalla and the University of Karlstad. It was assumed in the study that teachers' ESD competences could be observed as the school was implementing ESD.

\section{Philosophizing with}

In the theoretical studies and in the overall design of this thesis, philosophical arguments are blended with empirical findings. It is frequently the case that philosophical studies are separated from empirical studies, but there are a great many educational issues that are as philosophical as they are empirical. Indeed,

\footnotetext{
${ }^{6}$ Swedish Council for Higher Education www.uhr.se/en/start/
} 
the empirical data might prove inadequate (Golding, 2015). Philosophizing with is used as a reflective and analytical method in this thesis (Dohn, 2011, 2018). It resembles applied philosophy in the sense that it serves practical concerns and that it is philosophy put to use. By letting philosophy or the branch of philosophy concerned with knowledge, epistemology, have a voice of its own in the analyses, concepts in ESD are challenged and advocated. Bob Jickling pointed out in the 1990s (Jickling, 1994) that the field of environmental education and ESD were underresearched when it comes to philosophical analysis. In particular, techniques of conceptual analysis are important, but it is misplaced to think that such research could provide a full and precise answer (Jickling, 1994). Through epistemologically oriented reflection, the concepts of ethical competence, action readiness, moral literacy, and normative competence, in general but specifically in the field of education for sustainable development, are a central concern of the analysis.

Rather than understanding the conceptual papers as studies adding one concept to another or replacing one concept with another, it is the philosophizing with that adds to the field of ESD and to the theory of methodology. In my interpretation philosophizing with is a methodological as well as a philosophical dialogue. At the heart of interdisciplinarity and transdisciplinarity is communication, and for that reason, philosophy is invited to have a voice of its own in the analysis. Philosophizing with has some similarities with phronesis and deliberation. In the interpretation of this thesis, philosophizing with contains aspects of renarration and offers reinterpretation. By renarration and integration of contemporary issues in epistemology and education, something new can be developed.

An interest in knowledge, what it is and how you come to know, is shared by philosophy and education (Kotzee, 2011). The branch within philosophy that specifically has this as its focus is epistemology. For that reason, both fields of study, and educational practice, could benefit from a joint interest in each other's fields of study. They should be in dialogue (Kotzee, 2016). In this thesis, epistemology is not used in an a priori analysis per se but serves the purpose of highlighting observable and empirical challenges of education regarding fundamental didactical issues of why, what, and how various aspects of knowledge could and should be in focus and approached. Thus, philosophizing with is not a solely theoretical approach. Philosophy as a dialogue partner means that philosophy is engaging with other sciences, such as educational sciences, and that what is being explored is inspired by empirical findings (Dohn, 2018). 
Moreover, a dialogue means a two-way exchange and the analysis directed by the method of philosophizing with has practical implications for education, as well as addressing relevant issues concerning knowledge and knowing in epistemology. It is a method that has similarities with transdisciplinarity in that it reaches across at least two fields of study. From the deliberations, you can learn non-empirically. When philosophizing with, you focus on the conditions that would be necessary, if and when something is applied in an empirical context, which is valuable knowledge in order to decide on what should be estimated as preferable or even true in a specific situation. At the same time, these conditions, this philosophizing with, serves a purpose in testing the theory per se.

\section{Reliability and validity}

The two research instruments that were developed for the empirical studies are evaluated in the sections Instrumentation and Research results, and more specifically in Papers II and V. Both questionnaires were piloted with similar participants, and they were not included in the sample.

Cronbach's alpha values are considered and the factor analyses in SPSS support the dimensionality and reliability of the instruments. There are two main challenges of construct validity. The first one is construct underrepresentation, which suggests that the instrument fails to capture the relevant aspects of the construct. The other is the opposite, constructirrelevance variance, which means that the conceptualization is too broad (Moss, 1995). In both cases the theoretical frameworks are crucial for the analyses, no matter how limited they may be. It is the conceptual framework that specifies the construct that is being measured and separates it from other constructs. By repeating items from previous questionnaire instruments, as is the case of SEBTE (Survey of Epistemological Beliefs in Transdisciplinary Education; Paper II), the items have already been validated and should be able to function well in a similar instrument. Translation of English items into Swedish needs to be thorough, sensitive to both the theory of epistemic beliefs and the participants in the study. In SEBTE, seventeen out of twenty-six items had been used in previous studies and were translated by the author of this thesis, who have a long experience of teaching the age band that the participants came from. Statistical method to test the validity and reliability of the questionnaire can be further found in Paper II. The second research instrument 
TESDC were constructed using previous theory on teacher competences, as no similar instrument was found in the literature. The theoretical grounding of the construct plays an important role for the construct validity.

External generalization cannot be established as the samples in both SEBTE and TESDC are convenience samples. However, the similarity in results between a convenience sample and a randomized sample has some empirical support, which nevertheless makes the findings from convenience samples relevant (Mullinix, Leeper, Druckman, \& Freese, 2015).

The emergent research design of the thesis works in a two-fold way. In one respect, the empirical studies are treated statistically and used as an inspiration for further theoretical analysis. On a theoretical level the theoretical analysis is aims to generalize the results, which means that some important findings from the empirical analyses are explicated further and thereby becoming trustworthy. Thus, the explications of the findings from the empirical studies, point in the direction of a field of importance. In that sense, the empirical studies are qualified by the theoretical studies, which themselves use previous literature as a foundation for the research. In another respect, by pursuing the concept using other authors within various fields, such as epistemology, education, and psychology, the results from the empirical studies are brought into contact with other literature already validated. The value of the findings of the limited empirical studies is to some extent validated and generalized by focusing attention on various concepts that can be related to the empirical findings. This argument is put forward in order to validate the theoretical studies. There are other means of validating the theoretical studies, one of which is my long experience and continued experience of teaching, while doing research. Another means of validating the results is to present the theoretical research at various scientific research conferences. The results of the theoretical studies have been presented for example at NERA in 2013, 2014 and 2015, at ECER in 2014, at the Nordic Research Conference on Environmental and Sustainability Education [Nordisk forskningskonferens om miljö- och hållbarhetsutbildning] in 2016, 2018 and 2021. See Table 6. 
Table 6 Paper proposals at research conferences

\begin{tabular}{|c|c|c|}
\hline Title of paper proposals & Conferences & Year \\
\hline $\begin{array}{l}\text { Concepts of knowledge and knowledge } \\
\text { creation among students and teachers in } \\
\text { transdisciplinary education }\end{array}$ & $\begin{array}{l}\text { NERA, Reykjavik, Network 5: The } \\
\text { Curriculum Research Network }\end{array}$ & 2013 \\
\hline $\begin{array}{l}\text { Epistemic beliefs, sustainable development } \\
\text { and knowledge creation in upper- } \\
\text { secondary education }\end{array}$ & $\begin{array}{l}\text { ECER, Porto, Network: } 30 . \\
\text { Environmental and Sustainability } \\
\text { Education Research (ESER) }\end{array}$ & 2014 \\
\hline $\begin{array}{l}\text { Philosophizing with sustainable } \\
\text { development and knowledge creation }\end{array}$ & $\begin{array}{l}\text { NERA, Lillehammer, Network 5: } \\
\text { The Curriculum Research Network }\end{array}$ & 2014 \\
\hline $\begin{array}{l}\text { Conceptions of ethical competence in } \\
\text { relation to action readiness in Education for } \\
\text { Sustainable Development }\end{array}$ & $\begin{array}{l}\text { NERA, Helsinki, Network 7: Value } \\
\text { Issues and Social Relations in } \\
\text { Education }\end{array}$ & 2016 \\
\hline $\begin{array}{l}\text { Teachers' approaches to ESD in a whole- } \\
\text { school development project [Lärares } \\
\text { förhållningssätt till lärande för hållbar } \\
\text { utveckling i ett verksamhetsutvecklings- } \\
\text { arbete för att hela skolan ska med] }\end{array}$ & $\begin{array}{l}\text { Nordic Research Conference on } \\
\text { Environmental and Sustainability } \\
\text { Education [Nordisk } \\
\text { forskningskonferens om miljö- och } \\
\text { hållbarhetsutbildning]Örebro }\end{array}$ & 2016 \\
\hline $\begin{array}{l}\text { Normative competence in ESD - a } \\
\text { practical-pedagogical concept? [Normativ } \\
\text { kompetens i lärande för hållbar utveckling- } \\
\text { ett praktiskt pedagogiskt begrepp?] }\end{array}$ & $\begin{array}{l}\text { Nordic Research Conference on } \\
\text { Environmental and Sustainability } \\
\text { Education, Örebro }\end{array}$ & 2018 \\
\hline $\begin{array}{l}\text { Perceived self-efficacy among upper- } \\
\text { secondary students in ESD [Upplevd } \\
\text { självtilltro inom ESD bland } \\
\text { gymnasieungdomar }{ }^{7}\end{array}$ & $\begin{array}{l}\text { Nordic Research Conference on } \\
\text { Environmental and Sustainability } \\
\text { Education, Oslo, digital participation }\end{array}$ & 2021 \\
\hline
\end{tabular}

Presentation of the research process and emergent concepts at various research conferences to increase trustworthiness and reliability.

At the same time, the argument put forward for the emergent research design is that it contributes to validating and making the results of this thesis trustworthy.

\section{Ethical considerations}

The ethical considerations and guidelines described in Good Research Practice (Vetenskapsrådet [Swedish Research Council], 2017) have been observed, and the present research project falls outside the scope of a legally based ethical review. Care was taken in relation to the participants of the two empirical studies in the present thesis so that they did not come to any harm. No personal information was gathered from the research subjects that could have an impact

7 This presentation does not relate to a paper that this thesis builds upon, but the concept of self-efficacy is related to epistemic beliefs and competence. This is a topic for a future research project. 
on their privacy. Participation was voluntary and analyses were made on a group level only, which allows for the protection of anonymity. Guidelines regarding the quality of research and good research practice have been considered throughout the research project.

In the two empirical studies, the questionnaires were group administrated. The students were informed orally by the researcher that their participation was voluntary (Paper II). The questionnaires were handed out to them as they entered the hall where the meeting was taking place and those who wished to participate handed in their questionnaires as they left the hall. The participating teachers in the other empirical study (Paper V) were informed orally in a great hall that the questionnaire was administered digitally, and that their participation was voluntary. See Appendix C. In both empirical studies, the researcher of this thesis was the teacher of some of the participating students and a colleague of a large community of the teachers in the second study, but in no case can these relationships be considered to have any significant impact on participation or responses. Both instruments were piloted and in the piloting of the questionnaire on teacher competences, one participant pointed out that he could be identified by stating his age. Therefore, age spans were used instead, in line with Borg, et al. (2013). 


\section{Chapter 5. Research results}

This chapter summarizes the main findings and arguments as presented in each article. The aim and method are briefly reported. All papers can be found in Part 2.

\section{Paper I - A phronesian ${ }^{8}$ strategy to the education for sustainable development in Swedish school curricula.}

The focus of this paper is the distinction between education about and education for sustainable development in the Swedish curriculum for compulsory school (Skolverket [Swedish National Agency for Education], 2011). We set out to investigate the interpretable variation among the four syllabi for geography, history, religious education and civics. The pluralistic use of the concept of sustainable development in the four syllabi for the social science subjects can be related to the definition of the concept as well as to the action required by it. There seems to be a tension between the knowledge base about and the development of practical knowledge for sustainable development.

How explicit the notion of action is in the syllabi varies. The syllabus for the subject of religious education lacks requirements relating to an action competence, although the syllabus may be interpreted as pointing towards ethical considerations. In the subject of history nothing is indicated when it comes to the question of how to act practically. In civics, questions concerning democracy and human rights are foregrounded. The societal perspectives relevant to sustainable development are made visible throughout the syllabus content, which nevertheless does not make concepts of action and action competence explicit. In the syllabus for geography, the conditions for life are

\footnotetext{
The adjectival derivation of phronesis varies. In our article we follow the -ian suffix in line with Trowbridge, R., H., \& Ferrari, M. (2011). Sophia and phronesis in psychology, philosophy, and traditional wisdom. Research in Human Development, 8(2), 89-94. A frequent, alternative derivation is phronetic, used by e.g., Flyvbjerg, B., Landman, T., \& Schram, S. (2012). Real social science applied phronesis. Cambridge: Cambridge University Press.
} 
depicted as changeable and vulnerable. It is stated that it is the responsibility of all to support sustainable development and thereby act in a way that reduces the risk of damage.

Bernard Williams's notion of thick and thin concepts (Kotzee, 2013) is applied in the interpretation of the pluralistic conceptualization of sustainable development. A thin concept is either purely descriptive or purely evaluative. By contrast, a thick concept is both. Sustainable development would seem to belong to the thick category due to its being theory-laden with various political and ethical theories. Furthermore, the distinction between thick and thin concepts can be addressed by using Kotzee's labels world-guidedness and action-guidingness. Sustainable development would seem to convey something true about the world which would justify certain ideas held by the believers. In that respect it is world-guided. Action-guidingness rather works towards the practical consequences of the world-guidedness. Both dimensions are incorporated by thick concepts.

Two processes are connected to world-guidedness and the actionguidingness respectively, the process of the justification of belief and the process of the justification of action. From a holistic perspective, these juxtaposed processes correspond to existential dimensions in life, believing and acting.

Aristotle's notion of phronesis, practical wisdom, can be identified in anyone who can see what is good for themselves and what is good for men in general. Bent Flyvbjerg uses the term phronetic social science, which concerns how to act and understand in a particular situation with the ultimate end of improving society. Phronesis is, so to speak, contextualized and true in a particular situation.

A phronesian strategy for the education for sustainable development would mean that students keep a critical attitude to the justification of belief, which in turn provides the justification for doing, so-called action knowledge. As Flyvbjerg points out, the end of practical wisdom (phronesis) is to improve society. The action or practical knowledge suggested by the syllabi for geography, religious education, history, and civics in the Swedish curriculum seem to be mainly of an analytical quality. It seems relevant to move the students from a state of awareness to an aptitude for action with action as an intrinsic quality of phronesis?.

\footnotetext{
${ }^{9}$ This summary is taken from my licentiate thesis frame with a few minor changes.
} 


\section{Paper II - Epistemic beliefs and knowledge creation among upper-secondary students in transdisciplinary education for sustainable development}

This study examines the epistemic beliefs (personal theories of knowledge and knowing) of upper-secondary school students $(n=208)$ involved in a transdisciplinary project regarding sustainable development. A questionnaire is used together with exploratory factor analysis to find out the dimensionality of the epistemic beliefs among the students. A three-dimensional framework (the structure of knowledge, the source of knowledge and the justification of knowledge) underpins the 26 item, self-report paper-and-pencil questionnaire, the Survey of Epistemological Beliefs in Transdisciplinary Education (SEBTE).

The factor analysis suggests five factors or dimensions: transdisciplinary knowledge, quick knowledge, certain knowledge, simple knowledge and collaborative knowledge. In the first factor - transdisciplinary knowledge knowledge is seen as complex, evolving and even partially contradictory. It speaks of an evaluative epistemology in which expert authority is recognized but looked at in a critical manner. This dimension seems to concern the structure and the source of knowledge. There is a strong individualistic sense in this factor, the capacity of the subject to create knowledge in and out of school.

The second factor - quick knowledge (quick learning in Schommer's framework) - is a dimension found by previous instruments. Quick learning quick and the speed of knowledge acquisition concern how you come to know, quickly or not at all. It could be interpreted as a determiner of knowledge. According to this epistemic belief, quick and effortless learning will bring about knowledge.

The third factor - certain knowledge - was a dimension identified by Schommer (1990). It appears to comprise dimensions concerning the source and justification of knowledge. School and research are seen as the basis for what is knowable. There is an answer to all questions, and you can find it. Knowledge is static and unchanging. You come to know through transmission. There is a sense of reproduction rather than creation.

The fourth factor - simple knowledge - was a dimension also established by Schommer (1990). In fact, two of Schommer's factors are merged in this factor: simple knowledge and innate ability. Simple knowledge suggests correct choices, right or wrong answers and seems to concern the structure of 
knowledge. It is related to the notion that coming to know is an innate ability. It displays a belief in school as a place to learn stable knowledge.

The fifth factor - collaborative knowledge - is associated with issues that might be referred to as collaborative knowledge, which one might argue could belong to the dimension of the structure of knowledge. Peers play a significant role in the creation of knowledge and integration of knowledge. Knowledge resides outside and between the subjects.

Table 7 Factors from EFA and project evaluation items

\begin{tabular}{lllll}
\hline $\begin{array}{l}\text { Factors (five) } \\
\text { independent } \\
\text { variables (EFA) }\end{array}$ & Item number & Item means & $\begin{array}{l}\text { Cronbach's } \\
\text { alpha }\end{array}$ & $\begin{array}{l}\text { Cronbach's } \\
\text { alpha if item } \\
\text { deleted }\end{array}$ \\
\hline TD knowledge & $\begin{array}{l}8,14,24,11, \\
7,23,12,19\end{array}$ & 4.9 & .77 & $.73-.75$ \\
\hline Quick knowledge & $\begin{array}{l}20,9,26,25, \\
18\end{array}$ & 2.9 & .68 & $.60-.65$ \\
\hline Certain knowledge & $\begin{array}{l}5,10,17,2, \\
1\end{array}$ & 3.6 & .61 & $.50-.59$ \\
\hline Simple knowledge & $\begin{array}{l}15,13,3,4, \\
16\end{array}$ & 3.9 & .55 & $.43-.53$ \\
\hline Collaborative knowledge & 21, r22, 6 & 3.5 & .46 & $.20-.37$ \\
\hline $\begin{array}{l}\text { Project evaluation- } \\
\text { dependent variable (MRA) }\end{array}$ & $\begin{array}{l}\text { B1, B2, B3, B5, B6 } \\
\text { B4, }\end{array}$ & 4.1 & .82 & \\
\hline
\end{tabular}

The five factors manifested in exploratory factor analysis (EFA) and the items belonging to the individual factors. Cronbach's alpha reports the internal reliability of the items within the individual factor. Items from the A-section of $S E B T E$ are reported as numbers only. Items from the B-section of SEBTE (students' evaluation of the educational project) are preceded by the letter $B$. The B-items make up the dependent variable in a subsequent multiple regression analysis (MRA). Number of decimals for means and Cronbach's alpha are reduced compared to the version in paper II.

The Cronbach's alphas are satisfactory but not very high. Despite this, the interitem reliability does not increase if any of the items that make up the factors are deleted. The span of alpha values reported in Table 7 above indicates that all the items can be retained, as deleting any of them will not increase the Cronbach's alphas.

The factors from the exploratory factor analysis were used in a subsequent stepwise multiple regression analysis. Five index variables were computed out of the standardized variables associated with each factor and used as independent variables together with dummy variables of gender, age, and 
education programme. The dependent variable was computed from the five context-specific items of the questionnaire, the students' evaluation of the whole project. In a stepwise regression analysis, one independent variable is entered at a time, starting with the most significant one. Three of the factors from the exploratory factor analysis were most significant in a positive way: collaborative knowledge, transdisciplinary knowledge, and certain knowledge. The seventh and final model is presented in Table 8 below.

Table 8 Multiple regression analysis, stepwise, model 7

\begin{tabular}{lcc}
\hline Independent variables & Standardized B coefficients & Standard error \\
\hline Collaborative knowledge & $.412^{* * *}$ & $(.300)$ \\
\hline Transdisciplinary knowledge & $.337^{* * *}$ & $(.299)$ \\
\hline Certain knowledge & $.221^{* * *}$ & $(.300)$ \\
\hline Male & -.102 & $(.669)$ \\
\hline Quick knowledge & $-.190^{* *}$ & $(.305)$ \\
\hline Technical-Scientific students & $-.191^{* *}$ & $(.711)$ \\
\hline Simple knowledge & $.140^{*}$ & $(.310)$ \\
\hline
\end{tabular}

Dependent variable: Sustainable development project evaluation. ${ }^{* * *}=p<.001 .{ }^{*}=p<.05$

Model 1-model 7: Intercept: 20.712 -- 21.849, Adjusted R²: .158 -- .411

According to this analysis, three dimensions of epistemic beliefs have a positive impact on the students' appreciation of the school project, whereas variables male and technical-scientific students had a negative impact. The significance of male was significant in earlier steps of the model building, but not in the final one. This result might suggest that students who think that knowledge is quick and effortless will not appreciate the educational project. There also seems to be a difference between students on the social-economic programmes and students on the technical-scientific programmes. The latter loaded negatively on the dependent variable. Clearly, the epistemic beliefs seem to have more significance than the background factors in the model. For educational practice, for both in-service and pre-service teachers, awareness of epistemic beliefs can be useful to understand students' success, motivation and shortcomings. In ESD, it could also prove important what epistemic beliefs students have when it comes to organizing education. 


\section{Paper III - Conceptions of ethical competence in relation to action readiness in education for sustainable development}

In a previous study (Paper I), the interpretative pluralism of the concept of sustainable development was elicited from four syllabi all belonging to the social sciences in the Swedish national curriculum. Such conceptual fluidity is expected to be reflected by the conceptualizations of competence that students are to develop according to the four syllabi. The aim of the study was firstly to present notions of ethical competence in relation to education for sustainable development, and secondly to promote action readiness as an empirical concept for future studies of competence in ESD.

Sustainable development is a multidimensional concept, and one way to approach the dimensions is to use the pillar method, with the frequently referenced dimensions of ecological, social and economic sustainability. It is mainly in the justification of sustainable action that the balancing of the three dimensions seems to be most applicable. However, some criticism has been raised that the pillar metaphor sustains traditional epistemologies of various disciplines. Despite this criticism, the pillars serve the purpose of drawing attention to previously neglected considerations and clarification of decisionmaking processes. The integrative approach of sustainability cuts across pillars and reinforces the gains of interrelatedness and interdependency.

In education for sustainable development, the element of action is of interest. How should action for sustainability be defined and detected? Key competences as conceptualized by OECD (de Haan, 2010) fall into three dimensions: interactive use of tools, interacting in socially heterogeneous groups and acting autonomously. In our interpretation all dimensions are unified by the notion of action, such as for example, action competence. The preposition for in ESD may be the object of a range of interpretations. A common idea in various interpretations seems to be that ESD can and should contribute to the development of ethical competence. Ethical competence is a concept open to many interpretations. A way to approach it is to look at expressions of ethical competence. The eight key competences presented by the OECD (2005) may be considered a map of such expressions. All eight key competences are interdependent and emphasize critical thinking, creativity, initiative, problem solving, risk assessment, decision taking and constructive 
management of feelings (OECD, 2005). They are unified in abilities of communicative, social and ethical growth.

Ethical competence can be linked to the arena of values education, characterized by a mediation of presumed knowledge about what seems to be right, wrong or even true in the context of moral issues. If ethical competence is going to be applicable in the ESD-context, critical ethical competence seems to be a concept to be open to. The interpretive analysis is guided by the terminology of Swedish policy documents, mediating knowledge and fostering. This means that on the one hand the concept of ethical competence needs both analytical and normative dimensions. Without the analytical dimension, which corresponds to the practical and world-guidedness (Kotzee, 2011) or without the normative dimension, which corresponds to the decisive foundation, there is a risk of the concept becoming too fuzzy. To further emphasize the action element and avoid the vocabulary of competence, the notion of action readiness is suggested. Action readiness does not correspond to a given action in a situation but invites action possibilities and shifts the focus to willingness to act in the sense of not refraining from acting. The pedagogy that underpins the concept is that engaging with sustainability issues in a critical and reflexive way will contribute to students' ethical competence development. It is action readiness that connects experience with behaviour rather than any preconceived rules, norms and truth-claims.

The aim of education as whole, and specifically ESD, seems to be the development of relevant competences that display independent action and democratic principles (Nussbaum, 2010). A good society builds on good democracy and good democracy demands that citizens can think critically about political issues, evaluate political leaders, recognize equal rights and show concern for other people (Nussbaum, 2010). Furthermore, the nation needs to be recognized as part of a complex world. Important abilities are critical thinking and empathetic imagining (Nussbaum, 2010). The suggested concept of action readiness can also be compared to competence-in-use (Ellström \& Kock, 2009), which focuses on the interaction between the individual and the task. It is the process that is emphasized impacted by factors relating both to the individual and the task. Ethical competence as an attribute of the individual can develop when students are placed in ethical conflict situations which require action. By providing students with spaces of dialogue and action possibilities and joining them in dealing with ethical issues through critical reflection, ethical competence and action readiness can surface. However, any evaluation might 
carry the risk of limiting the possibility for future thinking and innovation that depends on the fact that the concept is constantly being renegotiated, reconceptualized and reinterpreted.

\section{Paper IV - Philosophizing with transdisciplinarity, relational knowledge and ethics in education for sustainable development}

In this book chapter, the notions of transdisciplinarity, relational knowledge and ethics in ESD are approached from an eclectic, theoretical angle. The chapter raises epistemological, relational and ethical issues with regard to education for sustainable development and transdisciplinarity. For educational practice, transdisciplinarity in education on authentic, real-world problems in a joint venture with stakeholders outside of school, may be assumed to prepare students for dealing with epistemological variety and uncertainty. However, relational or interpersonal activities in education must not be limited to the organization of education in which learning is taken-for-granted or somewhat naively presumed to take place with the right orchestration of the task. It is also important in transdisciplinary ESD to be open to dimensions of education for values and moral education.

In this theoretical study, various theoretical frameworks and lenses have inspired the discovery of new patterns and new understandings. Methodologically, the exploration is guided by an application of philosophizing with (Dohn, 2011). By focusing on relational aspects in the knowledge creation process in ESD, epistemological issues might surface regarding what knowledge is necessary for the individual and the collective to develop sustainability knowledge and ethics.

One of the characteristics of transdisciplinarity is its centrifugal, problemdriven movement. It is what reveals itself in this gyration that can be captured by the teacher as an educative moment, an opportunity that cannot be predicted or determined, but needs to be sensed and seized. It seems that the teacher has to understand the role of ethics in the relational co-creation of knowledge in the transdisciplinary mode. Systems-thinking and holism are theories that underpin the transdisciplinary approach to solving global challenges of sustainable development. The interconnectivity of decisions and actions relating to systems thinking give rise to questions about how the human system is to be understood and related to the natural system. The human system, 
equated with the technological system, can be viewed as part of, inside of or outside of the natural system. It requires that people see themselves as parts of different systems and it requires ethical sensitivity. If sustainability is seen as a knowledge system, then the human being is part of it and beyond it but not in a hegemonic manner. The sense of place for the human being as part of or beyond the various systems rests on how the systems are defined and related to other systems. Developing knowledge about systems and their interrelatedness and considering one's own sense of belonging or lack of belonging to defined systems can be both an epistemic and an ethical objective of ESD. The methodology of systems thinking requires new competences and relations among the workforce, the general public and students. Awareness of the effects of the systems could be a necessary ethical driver for critical reflection on our responsibility and moral obligations within and between systems. Depending on the prioritized interpretation, various ethical issues concerning the relational processes will surface.

One lens applied in the book chapter is Nancy Tuana's conceptualization of moral literacy - involving three basic components: ethics sensitivity, ethical reasoning skills and moral imagination (Tuana, 2007). This framework translates the theoretical developments to the practical applications in the classroom and provides a strong pedagogical strand, suggesting that moral literacy is a most practical concept which could make significant contributions within ESD. Critical thinking and reasoning have a strong link to moral literacy. Nancy Tuana argues that moral literacy is a skill that should be fostered in school, as our complex society exposes children and students to various ethical issues, such as cheating in school, bullying and refraining from stopping a friend who has been drinking from driving her or his car (Tuana, 2007). In Tuana's conceptualization moral literacy is a skill that can be developed over time and fostered by teachers who are well acquainted with moral subject matter. Compared to the importance attributed to literacy in the context of mathematics, languages, science and reading, attention to moral literacy is scarce if not absent. Tuana uses the literacy concept for three reasons. Firstly, moral literacy is a complex concept that requires various advanced competences and skills. Secondly, moral literacy is seen as a continuum that students could have more or less of. Thirdly, it is a skill that education could foster. Moral literacy can be seen as one element of sustainability competence. However, it is more important to look at what practical manifestations are made in the name of moral literacy. 
With its holistic perspective, transdisciplinarity aims to consider all possible aspects of a problem as well as approaches to its solution. The focus in transdisciplinary knowledge creation is on different stakeholders in collaboration solving an issue or problem. The various stakeholders' learning processes will differ. This conceptualization is underpinned by a belief in constructed knowledge and that it is possible for the collective society to improve. It gives hope and it is a choice, to be ready to change and be transformed, knowing through being and doing. However, transdisciplinarity and other integrative approaches have been proposed as an ideal, without recognizing the backwash of conflicts and disharmonies in practice (Klenk \& Meehan, 2015; Kopnina \& Meijers, 2014) and consequently pose both epistemological and ethical concerns for educational practice. Values are founded in the relatedness and this relatedness provides a context for morality (Miller, 1986).

It might be relevant to develop the element of care in ESD. Shared care makes the educational moment one of mutual responsibility and a form of boundary-crossing takes place between the teacher and the student as the traditional roles of teacher and learner are to some extent transgressed. Learning together with one's teacher is a relational process that requires some development of epistemological strands of thought or epistemic beliefs. The process of collectively creating knowledge gives the opportunity for le moment $t^{10}$ to take place. It takes sensitivity and readiness, a willingness on the part of all

10 Le moment is a concept borrowed from the doctrines of the naturalistic nineteenthcentury thinker and literary critic, Hippolyte Taine, who sees le moment as historic time, and claims that the creation of the writer is determined by inner and outer factors at a specific point in time. Le moment, as used in this chapter, in an educative moment is rather inspired by the practical application of the faculty of le moment in a naturalistic drama such as Miss Julie by Swedish author August Strindberg. The biological heritage of the heroine (race) in combination with her upbringing without a mother (milieu) can indeed be seen as determining factors that led to the inescapable, tragic end where she commits suicide. However, in the play, le moment can be seen as a creative opportunity or chance-the seductive moment of the midsummer night's dance and music-which sets the whole process into play. Without le moment, la race and le milieu would not come into effect. It is this element of unpredictability, despite the author's intention to explain his characters through heredity and environment, that makes le moment a workable concept in the description of educative moments and spaces in ESD. It is its creative dimension that corresponds to what is required by the teacher in ESD. A similar concept has been introduced in Garrison, J., Östman, L., \& Håkansson, M. (2015). The creative use of companion values in environmental education and education for sustainable development: Exploring the educative moment. Environmental Education Research, 21(2), 183-204. 
the participants to act in favour of for example sustainable development. The individual becomes aware of and realizes her or his relational spaces, individually and collectively. The learning outcome of such knowledge-creating orchestration of education might be referred to as relational knowledge.

\section{Paper V - Teacher competences in education for sustainable development - the development of a questionnaire instrument ${ }^{11}$.}

Since the introduction of the UN's development programme - Global Action Programme (GAP) - in 2014, there has been an increase in activities in education that provide opportunities for students to develop the competences required to contribute to sustainable development. Teachers are expected to develop their own as well as their students' sustainability competences. Therefore, the study of teacher competences is of great importance. Empirical studies focusing on teachers' approaches to ESD are however limited, and so are quantitative studies of in-service teachers' approaches to ESD. This is one of the reasons why it is relevant to analyse the concept of competence, especially in relation to continued professional development in the ESD context.

The aim of the study was to develop a research instrument using a broad conceptualization of competence as a theoretical framework. The conceptualization can be described as holistic and integrated recognizing the multidimensionality of the concept. The dimensions of competence are proposed to be knowledge, practical abilities, ethical values, attitudes and emotions.

Two research questions were used to guide the considerations of these issues and the empirical work that explores them:

- How can ESD competence be operationalized in a questionnaire about teachers' approaches to the ESD teaching perspective?

- What correlations can be established between the dimensions of ESD competence and the background variables of sex, age, teaching area and years of work experience?

11 Paper published in Swedish with an English summary. The present summary corresponds to a large part to the English summary that was published in Pedagogisk forskning i Sverige. 
An exploratory factor analysis, principal component analysis, applying orthogonal rotation, was conducted using SPSS 23.0 to explore the dimensionality of the concept of ESD competence among the participating teachers. All the variables were used, which resulted in a four-dimensional model. See Table 9. The dimensions were named didactics (15 variables), motivation (5 variables), capacity (3 variables) and barriers (3 variables) based on the competence literature. 
Table 9 Rotated component matrix

Variables/questionnaire items ${ }^{12}$

The students gain knowledge about environmental issues in my classroom.

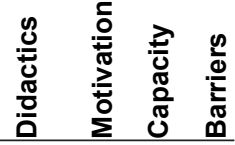

When I teach the students have the opportunity to develop concern about the values .84

of nature.

The students get the opportunity to put facts about nature and the environment into a .83 larger context.

My teaching makes it possible for the students to develop environmental awareness. .83

In my teaching, the students learn how the human being affects Nature.

My teaching contributes to the students' development of action competence for $\quad .81$

sustainable development.

In general, the students get to reflect on their individual responsibility for sustainable $\quad .79$

development.

$\begin{array}{ll}\text { My teaching encourages students to take environmentally friendly action.. } & .79\end{array}$

In my teaching, the students gain knowledge about the environment. $\quad .77$

I aim for students and teachers to mutually reflect on our common responsibility for $\quad .74$

sustainable development.

The students get the opportunity to use inquiry as a method of learning in education $\quad .72$

for sustainable development.

In my teaching, students are encouraged to value nature and the environment.

Education for sustainable development is a concept that has been given space in the .62 subjects/courses I teach

In education for sustainable development, we work together with one or several

other subjects.

In my teaching, there are opportunities to explore the local environment.

.58

It is important that the students' emotions about sustainable development are

accommodated

It is important to teach about and for sustainable development.

.79

I would like to learn more about education for sustainable development.

My principal supports my teaching for sustainable development. $\quad .48$

Education for sustainable development requires specific teaching methods.

I know of good examples of education for sustainable development that I can use in (.62) 48

my teaching.

I am aware of what is written about education for sustainable development in the first

.82

chapter of the national curriculum.

I have sufficient knowledge about sustainable development to include it in my

teaching.

$r$ It is pointless to bring up sustainable development in education.

$r$ It is hard to find good methods for teaching about sustainable development.

$r$ It is hard to find the time to include sustainable development in education.

Cronbach's $\alpha$

$(.44) \quad .42$

.79

\begin{tabular}{lllll}
0 & .58 & .67 & .58 \\
\hline
\end{tabular}

Extraction method: Principal component analysis. Rotation method: V arimax with Kaiser normalization. Rotation converged in 6 iterations. 
The proposed dimensions of competence are spread across the identified dimensions, except for the dimension of capacity, in which all the variables belong to the competence aspect of knowledge. It seems that knowledge is important for the competence aspect of capacity among the respondents. By contrast, the dimension of motivation does not contain a variable of the knowledge aspect, which might suggest that motivation is separate from knowledge in the integrated and holistic concept of competence. The largest dimension was didactics, which corresponds to the pedagogical work of teachers. The dimension named barriers is made up of variables relating to the proposed dimensions of feelings and practical abilities.

The variables that make up each dimension were transformed into sum variables and the demographic variables of sex, age, subject-matter category, and years of work experience were transformed into dummy variables before they were entered into bivariate analyses. No significant correlations could be established between the demographic variables and the dimensions, which suggests that the participants responded in a homogenous manner. This could depend on a specific school culture.

The questionnaire used in the present study to identify dimensions of teachers' competences in the context of ESD offers a new instrument for further research in the field. At the same time, it provides a practical tool in the implementation of ESD. Further research and methods are needed for a more finely grained analysis of the identified dimensions of teachers' sustainability competence.

The results of the study are limited by the fact that it was the first time that the research instrument was used. The Cronbach alphas were acceptable but not entirely satisfactory, which means that the instrument needs to be further developed and used in additional studies. In future studies, it will be relevant to examine whether the four-dimensional model of teachers' competence in the context of ESD can be established among teachers who are not actively implementing ESD.

\footnotetext{
${ }^{12}$ The questionnaire instrument was developed in Swedish. Here each item has been translated into English by the author for the purpose of this thesis frame, but further considerations are necessary before using the instrument in English.
} 


\section{Paper VI - Focusing moral literacy and normative competence in education for sustainable development}

ESD as transformative education can be identified by its integrative participatory, democratic, and process-oriented characteristics. These processes can lead to sustainability learning outcomes which involve normative judgement, which is a mental state involving thinking about what the case is and what ought to be the case. In a review article in the Journal of Moral Education it was stated that the specific normative requirements of various curricula should encourage research that explores educational theory, curriculum, and assessment (Lee \& Taylor, 2013).

The aim of the present article was to explore a conceptual grounding of normative competence, in relation to ESD. By examining emerging concepts of ethical competence and action readiness, and by building upon the framework of moral literacy for sustainable development, a space for the notion of normative competence is carved out within ESD. More broadly, what is studied is how normativity in ESD can be interpreted in an alternative manner so that pedagogical practice will neither be indoctrinating nor preclude the possibility of finding a predetermined answer to a particular question.

In the analysis Dohn's (2011) methodology of philosophizing with is applied, where philosophy is invited in dialogue to produce the results (Dohn, 2018). In addition, the method is informed by critically holistic thinking, tracing dimensions of normativity in the ESD literature. Elements connected to normative judgement for action are examined and directed towards processes involved in having reasons to believe and epistemic and normative reasons not to refrain from taking action.

As a basis for taking action, the theory of Nancy Tuana's three-component moral literacy is used as an analytical platform. Ethical sensitivity involves the ability to perceive the ethical issues in a situation, to be aware of its moral intensity and to be able to identify relevant virtues and values underlying the ethical situation. It is a foundation for students' opportunities to recognize ethical aspects as something distinguishable beyond personal choice, an invitation to engage in moral reasoning. This component comprises developmental processes that are not rooted in any inborn talent. It is a necessary but not sufficient condition for full moral literacy according to Tuana. The second component is ethical reasoning skills, with the subcategories of 
understanding various ethical frameworks, ability to identify and assess the validity of appropriate facts and ability to identify and assess values that individual and groups might consider ethical in the ethical situation. The third and final component of the model is moral imagination, a blend of affective and rational processes that contribute to the imagination. It attends to what is taken for granted and how an alternative could be envisioned.

In parallel, the virtue theorist Linda Zagzebski (2013) works from the assumption that moral theory aims primarily at explaining and justifying moral beliefs and practices rather than introducing what to do in a specific situation. However, theory may help us relate to our moral lives. Zagzebski suggests a connection to moral exemplars that will practically create the opportunity for an examination of what may be a good or a right way to choose. It is not personal characteristics that are in focus, but actions understood in relation to the contexts in which they are performed. Both Tuana's components of moral literacy and Zagzebski's moral theory of exemplars provide dimensions that in our interpretation are relevant in an analysis of normative competence. Tuana's components also seem to work in relation to the conception of ethical competence, although there will naturally be other ways of describing the core concepts.

The notion of action in the concept of competence requires that teachers provide instruction that incorporates practical methods of teaching and learning. Such practical considerations could be linked to the concept of action readiness previously introduced by Grice and Franck (2017). It relates to collective, transformative, and transdisciplinary aspects of normative competence. In educational practice, the students, individually or collectively, navigate between action possibilities without refraining from taking action. A competence-driven curriculum needs to go beyond theoretical knowledge transmission and include action in one way or the other. We believe normative competence could be a concept to address in various syllabi. Finding support in Tuana's moral literacy model and closely associated with the empirical concept of action readiness, normative competence moves the student from ethical imagination and reflection to ethical implemented action, because of his or her ethical seeing and knowing in the specific situation.

Normative competence is suggested here as a practical and alternative pedagogical concept which is domain-general, activated by the student, based on the epistemic reasons there are and the ethical reasons one has for implementing action for sustainable development. We believe that a 
reconceptualization of the competence concept is fruitful in pedagogy. It comprises both the learning outcome and the malleable process of learning, the sensitivity to context, carrying various dimensions of critical thinking and knowledge creation, set in motion by a change of belief or action.

\section{Synthesizing the empirical and the theoretical}

\section{studies.}

In figure 2 below, the key findings of the six separate research papers are synthesized in a flowchart highlighting central notions and conceptualizations.

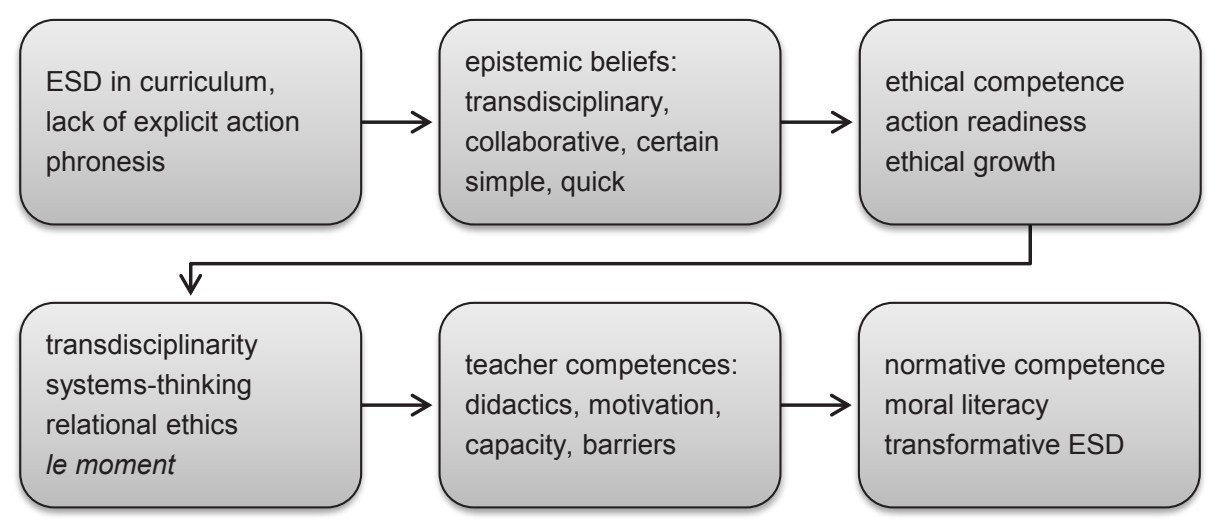

Figure 2 Results flowchart of papers I-VI

Education for sustainable development indicates some sort of practical knowledge base for action. However, in the Swedish syllabi for religious education, history, civics, and geography, it is only in the syllabus for geography that the notion of action is articulated. This indicates a plurality in the interpretations of the concept of sustainable development, which makes the concept contested when it comes to the aim of ESD, and makes the knowledge foundation, what is to be learnt in ESD, fluid. A phronesian strategy to ESD would entail both epistemic (world-guided) and ethical (action-guiding) notions. When examining the dimensionality of epistemic beliefs among students involved in a sustainability educational project, five dimensions were manifested: transdisciplinary, collaborative, certain, simple, and quick knowledge. A subsequent multiple regression analysis revealed that three of these dimensions had a prominent impact on how the students oriented themselves in the educational project: collaborative knowledge, transdisciplinary knowledge, and certain 
knowledge. As the various syllabi lacked the element of action in relation to sustainable development, ethical competence and action readiness were theoretically examined. Expressions of ethical competence were found to require both analytical and normative dimensions. Engaging with sustainability issues in a critical and reflexive way can contribute to ethical growth. Transdisciplinarity in ESD raises relational and ethical issues. One way to go is to develop knowledge about systems and consider one's own sense of or lack of belonging to the human and natural systems. With a link between critical thinking and moral literacy, we suggested that the teacher must understand the role of ethics in the co-creation of knowledge. Teachers and students learn in a relational process through epistemic, ethical, and practical boundary-crossing, in which the educative moment, le moment, might reveal itself. Tuana's threecomponent moral literacy model is a way of moving from theory to pedagogical practice. A concern is how implementation of ESD can be facilitated in the light of teachers' approaches. By developing a research instrument to explore inservice teachers' ESD-competence, a four-dimensional model was achieved consisting of the latent variables/factors: didactics, capacity, motivation and barriers. They are here interpreted as expressions of teacher competence and readiness for ESD. The final theoretical study foregrounds and leads onto the synthesis of the various studies. Scaling up ESD requires careful consideration of how to implement a sustainable learning process, at an epistemological and an ethical level. Normative competence as a practical-pedagogical concept and the notion of action in ESD are philosophized with. Nancy Tuana's framework for moral literacy and Linda Zagzebski's (2013) moral theory of exemplars direct attention to processes and relations involved in having reasons to believe and reasons not to refrain from taking action. The evolving studies and articles, together with methods and main concepts are illustrated by Table 10 below. 
Table 10 Overview of papers, main approaches, methods and concepts

\begin{tabular}{|c|c|c|c|}
\hline Papers & Approach & Analysis & Concepts \\
\hline I. Phronesian strategy & hermeneutical & interpretative & $\begin{array}{l}\text { education for } \\
\text { sustainable } \\
\text { development }\end{array}$ \\
\hline II. Epistemic beliefs & explorative & $\begin{array}{l}\text { theory-driven } \\
\text { factor analysis } \\
\text { regression analysis }\end{array}$ & epistemic beliefs \\
\hline III. Ethical competence & explorative & reflective & $\begin{array}{l}\text { ethical competence, } \\
\text { action readiness }\end{array}$ \\
\hline IV. Philosophizing with & abductive & reflective & $\begin{array}{l}\text { transdisciplinarity, } \\
\text { epistemic beliefs, } \\
\text { moral literacy }\end{array}$ \\
\hline V. Teacher competences & explorative & $\begin{array}{l}\text { theory-driven } \\
\text { factor analysis }\end{array}$ & teacher competences \\
\hline VI. Normative competence & explorative & $\begin{array}{l}\text { theoretical } \\
\text { reflective } \\
\text { philosophizing with }\end{array}$ & $\begin{array}{l}\text { action competence, } \\
\text { action readiness, } \\
\text { normative } \\
\text { competence }\end{array}$ \\
\hline
\end{tabular}





\section{Chapter 6. Discussion of research results}

The empirical studies in this thesis have aimed to explore the dimensionality of the two constructs, epistemic beliefs among students (Paper II) and teachers' ESD competences (Paper V). In synchrony with the empirical studies, the theoretical studies have aimed to explore and explicate findings and emerging concepts related to educational practice and research. Below, the results of each research question are discussed more specifically. They relate to didactical concerns in pedagogical work regarding what the students' epistemic beliefs are and how teachers can best address the ill-structured learning content of ESD, by developing their teacher competences that are sensitive to how students think about knowledge. Another question for educational practice is what competences teachers need to approach epistemic and ethical issues related to sustainable development. A third aspect highlights the moral dimensions of ESD in relation to the concept of competence. A few nested concepts raise important questions about what is to be learnt and what is to be taught in ESD. They all relate to the overarching notions of action, reflection, and critical holism, and can be used in various decision-making processes regarding what to do for sustainability, how to learn and create knowledge in sustainability contexts, and how to professionally address moral blind spots in education for sustainability. The conceptualizations remain open to revision.

\section{What epistemic beliefs can be identified among upper-secondary students involved in a transdisciplinary sustainability project? ${ }^{13}$}

To recapitulate, an overarching research interest in this thesis is how students orient themselves in a complex educational practice, such as ESD. An assumption is that students' epistemic beliefs, their personal beliefs regarding what knowledge is and what it is to know, are set in motion in a transdisciplinary ESD project. The complexity of the educational project can be found on two

\footnotetext{
13 Arguments on sophisticated and naïve epistemic beliefs have partially been presented in my licentiate degree thesis frame.
} 
levels. On one level there is the object of study. ESD issues are wicked problems with a knowledge base that is uncertain and contingent. On another level, the educational project is complex because of its organization, spanning across school and society and with external stakeholders involved. Simultaneously, transdisciplinarity and collaboration are two efforts in the global community's response to the wicked problems of sustainable development, and are applied in sustainability science as well as ESD. Both carry notions of agency and innovation necessary for change and transformation of individuals and society at large.

As mentioned above, the empirical context of Paper II is a specific transdisciplinary educational project regarding food, with 208 Swedish uppersecondary students from 16 different schools. As no epistemic-belief instruments designed for transdisciplinary school projects and knowledge creation could be found at this point in time, a new instrument (SEBTE) was constructed. It was assumed in the study that the dimensionality of the students' epistemic beliefs would have an impact on how the students oriented themselves in the transdisciplinary project. The SEBTE instrument introduced innovative variables/items regarding collaboration and transdisciplinarity, which seemed to be lacking in previous instruments. The added issues were based on notions of knowledge in ESD but also on the Swedish curriculum, where transdisciplinarity and project work are encouraged. Unfortunately, it is not possible to establish whether and how the students made use of the external experts. In retrospect, that would have been a relevant variable to explore. Of the five dimensions of epistemic beliefs that were manifested in the exploratory factor analysis, the largest one was transdisciplinary knowledge and the smallest collaborative knowledge.

The second step in the statistical analysis was to use the factors of the exploratory factor analysis as independent variables and correlate them with the dependent variable, how students evaluated and oriented themselves in the educational project regarding food. In the stepwise MRA, SPSS adds another variable at each step of the construction of the regression model. Three factors were the most significant ones in the MRA: transdisciplinary knowledge, collaborative knowledge, and certain knowledge.

In the final model (Table 7, above), the belief that knowledge is quickly developed without any effort, quick knowledge, loads negatively on the dependent variable, which confirms the results of previous studies (Azevedo, \& Torney-Purta, 2008; Bråten \& Strømsø, 2004). The background variable, the 
technical-scientific field of study, also loads negatively on the dependent variable. From this result, it is possible to theorize that the belief quick knowledge has a negative effect on how students orient themselves in this educational project. The amount of work needed from the student is probably large and the teachers might have adopted a more supervisory role. As far as the field of study is concerned, it might be possible to find that the concept of knowledge within a specific school subject or discipline will favour a belief such as quick knowledge. Whether this is the case with the background variable, technical-scientific study programme, cannot be established, but the results indicate some support for that. This does not mean that the epistemic culture of that school subject is less sophisticated. The value relationship between epistemic beliefs and a particular school subject needs to be looked at pragmatically, and based on what the situation requires.

The dimensions of epistemic beliefs that were manifested in the empirical study (Paper II) understood in relation to the notions of sophistication could also be interpreted as more or less inherently sophisticated. Transdisciplinary knowledge, which proved to be the most important of the dimensions of epistemic beliefs, combines both theoretical and practical notions of knowledge and how to come to know. This could suggest that students at the sophisticated end of the variable continuum would see how they contribute to the knowledge creation together with other stakeholders, and that they think critically about what knowledge is created and consider the problem-solution from an ethical point of view. However, the knowledge claims that can be made by using the statistical methods of factor analysis and multiple regression analysis can only provide proof of the covariation of variables. The interpretation of what this might entail in educational practice requires further research.

By applying a theoretical analysis of the concepts involved, it can be established that transdisciplinarity in itself combines the theoretical with the practical. Perhaps it would be possible to argue that the practical notions in transdisciplinarity are methodological. By reaching across school subjects, and disciplines, and including various stakeholders, it is not what you know that comes into focus, but the joint venture in problem-solving. Transdisciplinary and collaborative beliefs seem to play an important role here. In the school project, three epistemic beliefs seemed to be most important when it came to how students oriented themselves in transdisciplinary education. The first two, transdisciplinary and collaborative knowledge beliefs, seem to be important as far as the practical dimensions of transdisciplinary education are concerned. 
The third dimension of epistemic beliefs that had an important impact on the dependable variable was certain knowledge. The students seemed to believe in the possibility of certain knowledge. How this dimension relates to the previous two epistemic beliefs is not possible to establish from the data in this thesis, but it could be interesting to explore further.

By philosophizing with, extending the empirical results philosophically, further inquiry can be fostered and encouraged. Theoretical research carves out new empirical ground, relevant to the field of ESD. In the school project, there is reliable knowledge to be created together with experts or other stakeholders, but it is the student themselves who construct the knowledge and write chapters for a book, which is published. As some authors argue, transdisciplinary approaches build on self-reflection, an open and inclusive attitude towards others, and a willingness to engage with others (Popa, Guillermin, \& Dedeurwaerdere, 2015). It seems reasonable that epistemic beliefs are important antecedents in students' development of various competences, and that transdisciplinary education can provide a good space for students to grow both ethically and epistemologically.

Two background variables enter the model. The male sex has significance through three models but not in the last one. Here the results are not conclusive when it comes to the significance of gender. As most students in the technicalscientific programmes (fields of study) are male, it might be that this difference between men and women is disguised in the MRA by the field of study. This needs to be explored further. Age is a background variable that does not enter the model at all. In the stepwise model building, the three dimensions of epistemic beliefs: collaborative knowledge, transdisciplinary knowledge, and certain knowledge, are the most significant. It is interesting to notice that epistemic beliefs seem to have a more powerful effect on the dependent variable in comparison to the background variables.

There are statistical reasons to look at the results as tentative, as the instrument is new. The statistical arguments are most relevant if one's research interest is in finding a specific model with a set number of dimensions of epistemic beliefs. If a more pragmatic, exploratory, and interpretative approach is applied, there is sufficient evidence of the importance of epistemic beliefs to carry on research along the same vein as in this thesis. There is sufficient evidence of the impact of epistemic beliefs to inform educational practice and include knowledge in this field in the orchestration of education, not only in ESD, but more generally. 
It would be interesting to explore further the relationship between epistemic beliefs and competence. Transdisciplinary knowledge beliefs (TKB) could also be interpreted as a competence or a valuable antecedent for competence development. TKB could be a competence that would make it possible to handle ill-structuredness. It addresses the role of the individual and the group in relation to an ill-defined problem. An interesting distinction between the two dimensions of transdisciplinary knowledge and collaborative knowledge is the individual aspect of transdisciplinary knowledge and the group aspect of collective knowledge. In transdisciplinary knowledge, the point of view is the individual, seeing and knowing how he or she relates to other stakeholders and fields of knowledge. In collaborative knowledge, the point of departure is the group, the system. Both perspectives are relevant to ESD.

However, an interesting research topic in personal epistemology is the interaction and interconnectedness between epistemic beliefs and the educational context. This relates to two concerns in personal epistemology research. The first one concerns how epistemic beliefs develop, which is not the focus of the present thesis. The second one, relates to the issue whether epistemic beliefs are domain-general, domain-specific, or even topic-specific. Although, this is not the main focus of the present study, the statistical analyses suggest that there is reason to believe that there is a relationship between the educational topic, the way education is organized, and the epistemic beliefs that are activated in the participating students. This is a hypothesis that has emerged from the present thesis, and I suggest that it is worth exploring in future research.

As mentioned above, it could also be possible to analyse epistemic beliefs as antecedents of or indeed dimensions of competence. If competence is defined as knowledge in use, such research could fall under the panoply of epistemic cognition (Hofer, 2016). It would be interesting to further examine empirically how epistemic beliefs might interact with competences such as systems thinking, future thinking, and normative competence. 


\section{What dimensions of teachers' ESD competences can be identified among teachers at an upper- secondary school?}

As pointed out by other authors, there seems to be a lack of research instruments in the field of teachers' ESD competences (Cebriàn et al., 2020). Therefore, initial steps in the development of such an instrument were taken in this research project. The Teachers' ESD competences (TESDC) instrument was administered digitally. In the factor analysis, four dimensions of teachers' ESD competences were manifested. The dimensions were named didactics (15 variables), motivation (5 variables), capacity (3 variables), and barriers (3 variables). The initially proposed competence aspects, which were based on a broad conceptualization of competence (Cebriàn \& Junyent., 2015) are spread across the manifested dimensions, except for one. The manifested competence dimension capacity consists of variables that all belong to the proposed competence aspect of knowledge. This indicates that all the variables that were developed on theoretical grounds also correspond to the manifested variables from the empirical context. A possible way to interpret this is that the dimension of knowledge is of great importance when teachers evaluate their capacity for teaching.

The competences identified in this study may be referred to as teachers' professional implementation competences in ESD, in line with Bertschy et al. (2013). The dimensions identified in the factor analysis refer to professional aspects of teaching. Do the teachers have the knowledge, the motivation, the self-efficacy, and the opportunity (school-oriented and organizational aspects) to provide ESD? In the results section, it was suggested that school culture could be the reason why the participating teachers displayed similar approaches to ESD and that there were no differences when it came to what subject the teachers are specialists in, or how long they have been teaching. School culture, which was not explored in this thesis, might be such a strong factor that other background variables such as the length of time the teachers have been teaching or their subject expertise, although relevant, might have been overshadowed by school culture. The topic of ESD might not be perceived by the teachers as different to any other cross-curricular topic that is highlighted in education. This does not mean, however, that the results are less valuable. In fact, the teachers at the upper-secondary school had many years teaching experience, 
which could have had a larger impact on their self-perceived efficacy than the subject matter of ESD.

If teachers' ESD competences to some extent should mirror the competences the students develop, epistemically and ethically, it might be relevant to increase the number of items in the instrument TESDC by adding competence categories building on the framework by Rieckmann (2018), UNECE (2011, 2012), and UNESCO (1996), and in that manner not only explore teachers' pedagogical competences, but subject- content competences too. In the present study, all the variables that relate to what students should learn, as well as with whom, where, and how, go into the first and the biggest factor of the factor analysis. This factor was named didactics, as it relates to teachers' professional knowledge (Bertschy et al., 2013). In further development of the TESDC instrument, Rieckmann's framework (2018) could be useful, as the competence aspects that the students are supposed to develop in ESD can guide and increase the number of items in TESDC, given that teachers and students share the same responsibility for our planet. This aspect could motivate inclusion of items corresponding to ethical competence in the research instrument.

As TESDC is a new instrument, it needs to be used in further studies to increase its validity and reliability. Despite the fact that the results can only be considered tentative and fluid, they draw attention to practical dimensions of teachers' ESD competences. The dimension barrier is obviously one to pay close attention to in research.

\section{How can moral literacy, and epistemic and ethical dimensions of ESD, be related to conceptions of competence?}

Understanding epistemic beliefs in relation to other cognitive and affective concepts such as competence seems to be of interest for theory development as well as the development of further survey instruments in ESD. It seems that transformative learning and transformative pedagogy are at the centre of attention in ESD (Lotz-Sisitka, 2017). A crucial concept is change, on an individual as well as on an educational and institutional level. The paradigmatic character of this third-order change (Sterling, 2011) has been brought about by using new, integrated knowledges, a flexibility in epistemic beliefs, moral literacy, and a transdisciplinary mode of thinking and learning. In fact, the 
recent synthesis of sustainability competences by Rieckmann (2018) seem to provide a comprehensive set of competences that need to be developed in individuals, groups, education, and society at large.

The new paradigm of transformative education as expressed in Rieckmann (2018) resonates well with Tuana's moral literacy (2007). The three basic components of moral literacy serve a pedagogical purpose when students need to find an ethical solution. Ethical sensitivity is an ability to determine whether a situation involves ethical concerns or not. In all the descriptions of the sustainability competences by Rieckmann, a moral aspect is made explicit, whereas Wiek et al. $(2011,2016)$ focus on strategic, practical, and collaborative aspects. The other two components of Tuana's moral literacy: ethical reasoning skills and moral imagination, correspond to expressing feelings and thought and finding an ethical solution respectively (Paper VI). Tuana uses the literacy concept because it is a complex concept. It is seen as a continuum that you can develop within, and that education could foster this development (Paper IV). It seems that Tuana's theory is pedagogical and in fact there is a similarity between the three components of her framework and my own teaching philosophy of awareness, knowledge, and action. Tuana's moral literacy could be a possible foundation for the concept of normative competence in ESD, where ethical awareness, knowledge, and affective and motivational considerations, deserve further attention in research.

What has emerged in this thesis is a nest of epistemic and moral concepts that can be related to various conceptualizations of competence, embracing a broad conceptualization of competence which includes notions of action, based on epistemic and ethical justification. The lack of definition and inconclusive theory regarding the concept of competence is often put forward as a reason to be sceptical of the concept. In this thesis, the assumption is quite the opposite. The wavering interpretations might in fact contribute to its flexibility and applicability in various contexts.

An example of nesting concepts which emerged from the empirical studies and the emergent research design is the relationship between action readiness, ethical competence, and normative competence. The intention here is not to suggest a fully-fledged framework, comprising the three concepts, but to philosophize with them and, with interpretative care, to inquire into their interrelatedness. It would be possible to see normative competence as a practical and alternative pedagogical concept which is domain-general and could be developed across various contexts. It is activated by the student, who 
implements action for sustainable development based on the epistemic reasons there are, and the ethical reasons the student has, for not refraining from taking action. A sort of self-reflection is called for, so that the student learns to think about how they think about these issues. Being a competence concept, normative competence could be fruitful in pedagogy, as it comprises both the learning outcome and the malleable process, and a sensitivity to context. It brings with it various dimensions of critical thinking and knowledge creation, set in motion by a change of belief or action, both informed and intended action. Normative competence is by itself a domain-general concept, but the notion of competence makes it context-specific in the sense that it is sensitive to the situation. Knowledge will not be set in motion if this aspect of competence is not activated.

Competence-oriented educational concepts and curricula focus on the outcomes of a learning process but also on the application of that learning in new or different contexts. Competences include more than knowledge and understanding, and take into account the ability to apply that knowledge and understanding when performing a task (skill) as well as how - with what mindset - the learner approaches that task (attitude). The element of action in competence-oriented ESD needs to be addressed with care. For epistemic as well as ethical reasons, ESD cannot advocate specific action or change of behaviour. That would, according to Jickling and Wals (2012) be indoctrination rather than education. Kotzee's notions of world-guidedness and actionguidingness (Kotzee, 2011) can work as a heuristic in the critical thinking process or phronetic deliberation, in ESD research. The distinction is not necessarily productive in ESD on a universal level but can operate as a tool when engaging with the normative dimensions of a pluralistic worldview and pluralistic education for sustainable development. This is one way of making ethical competence, action readiness, and normative competence into practical concepts in education. In ESD research, it might be relevant to add another environmental teaching tradition to the fact-based, normative and pluralistic traditions (Östman \& Öhman, 2008). In transformative ESD, the various concepts above that relate to possible and actual action could serve as tools in the analysis. 


\section{Limitations of the studies}

The combined methods of the statistical and theoretical analyses exhibit different strengths and weaknesses when dealing with various aspects of a problem situation that is complex. The multimethodology aims to improve both reliability and legitimization, which are concepts relating to different research paradigms and might seem contradictory.

Two research instruments were developed and have not been used in further studies to establish their psychometric properties, which means that the statistical results are tentative.

The extended research design, which operates across the methodologies of empirical and theoretical studies, may be questioned. Another issue is the selection of research literature. It is mainly the northern or western discourse of research that is represented. One reason for this is that the empirical basis for the research project is a Swedish educational project. Another is the magnitude of the fields of research: fathoming a global scope is too vast for a thesis.

\section{Implications for education}

All teaching starts with the subject-matter that is to be dealt with, and how the students are invited to participate is crucial for the knowledge and competences they develop. The implication of the results and discussion of this thesis for educational practice is that epistemic beliefs deserve attention and need to be made explicit in education. In one of the studies in this thesis, the epistemic beliefs regarding transdisciplinarity and collaboration indicate that they might account for how students orient themselves in transdisciplinary, multistakeholder, educational projects. For teachers, it is relevant to consider the correspondence between students' epistemic beliefs and the outcome requirements in the national curriculum. With an awareness of epistemic beliefs, teachers may rethink and expand their own conceptions of knowledge and knowing. An awareness of epistemic beliefs, notions of action, and competence can inform effective learning and teaching within and across all subject areas. Any learning involves some sort of transformation, but transformative ESD learning involves ethical dimensions that the teacher needs to handle with care and sensitivity in response to the students. Normative competence is a practical pedagogical concept that can be useful if it is carefully defined and related to the specific educative practice. 
Considering the impact teachers seem to have on the students' results, there may also be reason to consider what epistemic beliefs the teacher may have. If a teacher has less sophisticated epistemic beliefs, they might organize education in a less challenging manner, by encouraging imitation as the mode of learning among students. Such means of learning may not make it possible for the students to develop intellectually and epistemically. By contrast, a teacher with more sophisticated epistemic beliefs may advocate reflection, and exploration of the reasons for learning the content in the chosen way. To facilitate transformative ESD, teachers need to get in-service, professional training, and teacher education needs to address the balance of epistemic and ethical development in student teachers. Exploring the dimensions of in-service teachers' ESD competences can be useful for the planning of teachers' professional development.

As has been argued previously, a broad conceptualization of competence might make the concept unproductive for educational research and practice, if too many competence aspects are included. My claim is that this is only a problem in a narrow conceptualization, when you expect to be able to tick off a laundry list of competencies. It is the flexibility of the concept of competence that makes it useful, both by its holistic approach to learning and knowing, and in addressing wicked problem-solving processes. It is a concept that makes it possible to approach a complex issue by framing processes or approaches in a creative and flexible way forward.

The transdisciplinary mode of teaching and learning includes a form of boundary-crossing between the teacher and the student. The traditional roles of teacher and learners are transgressed when the teaching-learning nexus is perceived as a relational process. The process of collectively creating knowledge, learning with your teacher, gives the opportunity for le moment to take place. Le moment is an educative moment which relies on the sensitivity, creative qualities, and moral disposition of the teacher. All the participants in such collective knowledge creation need to have a sensitivity to ethical aspects, a readiness not to refrain from taking action, and a willingness to be open to various conceptualizations of knowledge and ethical issues involved in the process. What is most significant with regard to le moment, in the relational cocreation of knowledge and shared sustainability responsibility, is that the participants become aware of and realize their relational spaces, individually and collectively. In education, the individual student perceives reflectively and reflexively the relational space, where new knowledge can be created. The 
processes and approaches involved can be juxtaposed to the levels of learning according to Sterling's typology (2011). The learning levels progress from a conformative mode, to reformative, and finally transformative. It is possible to conceive of the corresponding teaching traditions also following a developmental scheme, in terms of more advanced or sophisticated. The teaching traditions could also be conceived as a structural change, which would correspond to a change of types of teaching style, along the lines Illeris' theory of transformative learning which was developed in response to the concept of competence (Illeris, 2004). The type that Illeris refers to as transformative involves all dimensions of learning: the cognitive, the emotional, and the social dimensions. It changes the knower's personality. In this thesis, it is not seen as indoctrination or behaviour-related, as transformative ESD needs to make it possible for transformation to happen, and it is by competences displayed, epistemic and ethical, that it can be identified. (See Table 11)

Table 11 Types and levels of change, knowledge, and learning in ESD

\begin{tabular}{|l|l|l|l|}
\hline $\begin{array}{l}\text { Orders of } \\
\text { change/learning }\end{array}$ & Seeks/leads to & Can be labelled as & $\begin{array}{l}\text { Epistemic and } \\
\text { ethical processes } \\
\text { and approaches }\end{array}$ \\
\hline $\begin{array}{l}\text { First-order change } \\
\text { cognition }\end{array}$ & $\begin{array}{l}\text { Effectiveness/ } \\
\text { efficiency }\end{array}$ & $\begin{array}{l}\text { 'Doing things better'. } \\
\text { Conformative }\end{array}$ & $\begin{array}{l}\text { Knowledge about SD } \\
\text { epistemic, fact-based }\end{array}$ \\
\hline $\begin{array}{l}\text { Second-order } \\
\text { change } \\
\text { meta-cognition }\end{array}$ & $\begin{array}{l}\text { Examining and } \\
\text { changing } \\
\text { assumptions }\end{array}$ & $\begin{array}{l}\text { 'Doing things better'. } \\
\text { Reformative }\end{array}$ & $\begin{array}{l}\text { Knowledge for SD } \\
\text { ethical, normative }\end{array}$ \\
\hline $\begin{array}{l}\text { Third-order change } \\
\text { epistemic learning }\end{array}$ & Paradigm change & $\begin{array}{l}\text { 'Seeing things better'. } \\
\text { Transformative }\end{array}$ & $\begin{array}{l}\text { Knowledge as SD } \\
\text { epistemic and ethical } \\
\text { pluralistic }\end{array}$ \\
\hline
\end{tabular}

Sterling's (2011) levels of learning and change (the students' learning), have been extended by the author of this thesis with epistemic and ethical dimensions, based on types of knowledge and teaching traditions (Öhman, 2008), bighlighted in grey.

To sum up the discussion, there are normative elements in school policy documents that could be understood as relating to ethical and normative competence. The conceptions of competence, ethical competence, action readiness, and normative competence, combine epistemic and ethical dimensions of knowledge for change and transformation of society for a sustainable future. In terms of action, it is important to recognize that any action requires ethical considerations, but all actions are not sustainable. Consequently, 
there is motivation for education to investigate spaces where knowledge creation can take place, with the guiding principle of normative competence (Franck, 2017), which is action founded in volatile commitment, and where the very framing of space, the situation in which students decide to take action, is left to the student's free will.

Rather than directing attention to the variables of competence as the unit of analysis, attention could be directed to the student who takes a prosustainability stance, who embraces certain beliefs and normative values that will guide their action, and thereby develop a normative identity. This resembles action competence as reported by, for example, Almers (2013), but for the purpose of identifying ethical competence, turning to moral exemplars is a nonvariable approach that could be interesting to pursue. In Linda Zagzebski's exemplarist virtue theory (2013), moral exemplars are identified by what they do rather than who they are.

\section{Conclusions}

The contribution of this thesis does not rest on the distinct findings regarding epistemic beliefs and competences, but on how these are put together, introducing a larger and perhaps alternative picture of ESD. The illustration of the varying interpretations of sustainable development in the four syllabi for the social science subjects in the Swedish curriculum for compulsory school can be understood as indicating a sensitivity and carefulness in not putting forward too normative and indoctrinating goals for education. The curriculum is obviously a political document that is characteristic of its time, and when it is time for the next revision, the results in this thesis speak for explicitly introducing epistemic and ethical dimensions of knowledge, and suggest that the notion of action, and perhaps even normative competence, should be introduced.

It is possible to see this thesis as an unfolding of issues related to a paradigm shift towards transformative ESD. It moves through the processes of awareness: what education for sustainable development is or could be, through various epistemic and moral issues regarding what knowledge is or might be in ESD, to finally reach the evaluative level of knowing and being by focusing on action, not refraining from doing something. As mentioned previously, in my own teaching, I have applied a framework for myself as an educator and for the students on the course Building a sustainable society, involving levels and types of 
thinking and learning, which I have named awareness, knowledge, and action. While doing theoretical research as a $\mathrm{PhD}$ student, I have experimented with, perceived, and critically viewed the various concepts that have been at the centre of this thesis. I have been co-teaching with various teachers, and interacted with external stake-holders. I have worked alongside and together with my students in their empirical studies, collecting and analysing data in a whole-class project. As suggested in Paper IV, education ${ }^{14}$ as relational process for participating in sustainability practice requires a teacher that is epistemologically and pedagogically flexible. Whether in or out of school when teaching, the teacher needs to open to interacting with students, teachers, office staff, or other stakeholders in society. This transdisciplinary approach can be linked to a holistic worldview, which together with relational being (Paper IV), makes up a critique against the individualistic society. Transdisciplinarity provides a context for morality, and values are founded in relatedness. I have experimented with the mode of assessment of the competences that my students have developed through reflective learning and evaluation logs. Mindful of students varying epistemic beliefs, I have sought to be increasingly explicit when it comes to the content of knowledge in my teaching and when approaching students that are over- or underachieving. This awareness has given me new avenues of approaches in meeting, teaching, and facilitating the learning for my students. In my research, the practical experience of teaching for more than thirty years has offered an empirical facet to the theoretical analyses.

For the student in transdisciplinary education, it is likely that sophisticated epistemic beliefs operate as antecedents to the necessary boundary crossing. The student needs to become aware of the boundaries between fields of knowledge and between various stakeholders. Boundary crossing might not be exclusive to transdisciplinary education, and therefore it might be possible to think of all knowledge creation as boundary crossing. Boundary crossing in the epistemic sense is a moment of possibilities, for the individual to take an epistemic leap. There is also an ethical side to boundary crossing. The student needs to be sensitive to the educative moments and to be motivated to cross the boundary epistemically, ethically, and practically.

Despite the general aims of ESD, that students should be given a chance to orientate themselves among existing viewpoints, achieve knowledge and ethical

${ }^{14}$ Direct quote from Paper IV 
awareness to critically evaluate alternatives, develop abilities to take action, and be invited to participate in sustainability activities, there is still reason to remain critical towards education for sustainable development. Despite hopes for the possibility of creating sustainable changes in our globalized world, sustainable development overall is supported by the economic growth rhetoric. There is the visionary element as well as the risk of indoctrination to consider. That means that without a critical approach and without including both epistemic and normative competence in the action-guiding, decision-making processes, sustainable development and ESD could have the opposite effect to the intended one, with unsustainable consumption, loss of biodiversity, and climate change as its immediate consequences (Kopnina, 2020). The necessity of remaining critical reaches beyond the content of education. In studies of implementation, ESD schools have revealed negative effects when it comes to knowledge development compared to students who attend schools who do not work actively with ESD (Olsson, Gericke \& Chang-Rundgren, 2016). An inefficient implementation could also have negative societal effects (Jickling \& Wals 2012; Lotz-Sisitka, Wals, Kronlid \& McGarry, 2015). This criticism is based on the demand for a transformative and process-oriented education to meet the challenges of society, with a clear and ecocentric approach (MolinaMotos, 2019). Teachers who are willing to be open to the broad and inclusive educational concept of competence might be motivated to take part in professional development, and to use guiding principles for orchestrating educational and holistic, as well as collaborative and critical methods of evaluating the students' knowledge creation.

\section{Engaging with an emergent research design and extended methodology}

How relevant is it to make a conceptual and reflective analysis based on empirical studies? The research design of this project has resulted in an analysis of epistemological and methodological aspects of ESD emanating from an empirical study on epistemic beliefs. The theoretical studies have contextualized and criticized the concepts of education for sustainable development, competence, ethical competence, action readiness, and normative competence in an exploratory way. By combining empirical and philosophical analyses, an extended description of the research topic was gained, compared to a monomethodological or a single quantitative or qualitative perspective study. 
The contribution of the theoretical studies of this thesis is not to confine and define the concepts in a conclusive manner but to philosophize with them, and by doing so, expanding them and even recommending them for educational practise and further empirical research. The results offer teachers, teacher educationalists, and curriculum designers' ways of thinking about epistemic beliefs and normative competence by providing new actionable knowledge in the field of ESD.

In conclusion, research in ESD needs to be developed both theoretically and empirically. The introduction of new concepts in the field means new possibilities for critical reflection and change. Diverse forms of knowledge are called for in the transdisciplinary approach of ESD pedagogy. If students are recognized as stakeholders and co-producers of knowledge, it is relevant to explore how their epistemic beliefs interact with these processes. The possibilities and barriers of transdisciplinary ESD need further research using creative methods. With its integrative, participatory, democratic, and processoriented characteristics (Paper VI), transformative ESD requires a practical pedagogical concept that combines normative thinking and epistemic change. Therefore, normative competence is philosophized with in this thesis. In a similar analytical approach, action readiness is suggested as an empirical concept with its elements of willingness, capability, and commitment to act and change. The concept of competence in its broad conceptualization can capture the students' full knowledge and competence, according to which they develop a belief that they have the capacity to meet the challenges of sustainability, and find epistemic as well as ethical reasons not to refrain from acting. 


\section{Chapter 7. Summary in Swedish}

Budskapet i den senaste rapporten från FN:s klimatpanel pekar otvetydigt på att vi befinner oss i en klimatkris och att det krävs systemförändringar för att möta dess utmaningar (IPCC, 2021). Undervisning för hållbar utveckling (UHU, engelska: Education for Sustainable Development, ESD) är ett forsknings- och undervisningsområde som har olika samhällsutmaningar som sitt fokus. UHU är också ett forskningsområde som i flera avseenden innebär möjligheter till kritisk reflektion kring vad kunskap är, hur den ska omsättas i en didaktisk praktik och hur elever ska kunna tillägna sig den. I undervisningspraktiken ställer UHU nya krav på vad elever ska lära sig och vilka kompetenser lärare behöver utveckla för en undervisning som till sitt innehåll och sin form kan möta det transformerande samhälle som efterfrågas (Andersson, et al., 2013, Mochizuki \& Fadeeva, 2010; Varga et al., 2007). Trots en mångårig satsning på miljö- och hållbarhetsundervisning i den svenska läroplanen, uppvisar det svenska utbildningsväsendet otillräckliga förändringar för att kunna bedriva utbildning som säkrar planetens och mänsklighetens välmående (Kramming, 2017). Parallellt med klimatkrisen visar sig också ett slags inflätad kunskapskris. Elever har en oöverträffad tillgång till information och behöver kunna hantera och förhålla sig till såväl varierande som motstridiga fakta via ny, digital teknik (Muis, Pekrun, Sinatra, Azevedo, Trevors, Meier, \& Heddy, 2015). En viktig ansats inom undervisning är således att fostra elevers kritiska tänkande och källkritiska medvetenhet.

\section{Introduktion och forskningskontext}

Didaktiska kännetecken på UHU som den framträder i litteraturen är att den är holistisk och omdanande genom sin kritiska blick på vad eleverna ska lära sig; hur, var och när; med eller av vem, och inom vilken lärandearena. UHU ställer därigenom nya krav på lärares kompetens (Bertschy, Künzli, \& Lehmann, 2013) vad gäller didaktiska förmåga samtidigt som det ger möjlighet att pröva innovativa utbildningsformer och att anta olika kritiska perspektiv. Inom undervisning för hållbar utveckling fokuseras agens (Bandura, 2018), elevers demokratiska handlingskompetens (Almers, 2013; Lundegård \& Caiman, 2019; 
Mogensen \& Schnack, 2010; Rudsberg \& Öhman, 2010) och transformativa lärande (Leal Filho et al., 2018; MacIntyre, Lotz-Sisitka, Wals, Vogel \& Tassone, 2018; Sterling, 2014). Enligt UNESCO (2018) handlar undervisning för hållbar utveckling (UHU) om att möjliggöra för medborgare att på ett konstruktivt och kreativt sätt möta olika globala utmaningar och skapa hållbara och uthålliga samhällen. Den pedagogik som i litteraturen föreslås fostra hållbarhetskompetenser av det här slaget skildras som elevbaserad, erfarenhetsbaserad, aktiv och deltagande, transdisciplinär, transformativ och etisk (Borg et al., 2012; Sandell, Öhman, \& Östman, 2005; Öhman, 2008).

För att skapa en hållbar framtid och möta de komplexa miljö- och samhällsutmaningar vi står inför anses expertis inom en disciplin inte vara tillräcklig (Guimarães, Pohl, Bina \& Varanda, 2019), utan olika tvärvetenskapliga angreppssätt förespråkas. Det transdisciplinära angreppssättet kan sägas ha två komplementära inriktningar (Darbellay, 2015). Den ena inriktningen är av en epistemologisk natur. Den ser transdisciplinaritet som en kunskapsprocess som överskrider disciplinära gränser och därmed rekonfigurerar den disciplinära indelningen. Den andra inriktningen är av pragmatiska natur, där deltagande och tillämpad transdisciplinaritet framträder som en metod som sammanför vetenskapssamhället och olika sociala och ekonomiska intressenter liksom vanliga medborgare i själva forskningsprocessen för att hitta lösningar på problemen. Just denna pragmatiska inriktning (Darbellay, 2015) står i fokus för den forskning om transdisciplinära undervisningspraktiker som presenteras här.

De olika dimensionerna av tvärvetenskaplighet, möjligheter och hinder, mellan multi-, inter- och transdisciplinaritet inom akademien speglas också av gymnasieskolans ämnesindelning (Nordén, 2018). Med stöd av ämnesövergripande arbetssätt kan frågor behandlas som belyses ur miljömässiga, sociala och ekonomiska aspekter (Björklund, 2014, Murphy, 2012, SOU 2004:104). Därtill kommer etiska (Burford et al., 2013) och politiska frågor om ansvar för framtida generationer och globala frågor om rättvisa (Sund, 2014).

Om UHU betraktas som en arena för utveckling av demokratisk handlingskompetens (Breiting \& Mogensen, 1999; Mogensen \& Schnack, 2010) och delvis en politisk arena (Öhman, 2008) förefaller vad Sohl (2014) benämner som politisk självtilltro ha betydelse för den agens elever kan utveckla. Politisk självtilltro kan konceptualiseras som allomfattande, tvådimensionell, självtillitsinriktad eller multidisciplinär (Sohl, 2014), där olika fokus och 
individens tro på sin egen förmåga att agera politiskt och det politiska systemets mottaglighet för denna aktivitet sammanflätas. Även om begreppet självtilltro inte utvecklas vidare inom ramen för denna avhandling, förefaller det relevant för vidare forskning inom handling för hållbar utveckling.

\section{Problemområde och syfte}

En utgångspunkt för forskningen inom ramen för denna avhandling är hållbar utveckling i ett utbildningsperspektiv. En annan utgångspunkt är den svenska läroplanen för gymnasiet där det skrivs fram att kunskapsbegreppet kräver en aktiv diskussion om vad kunskap är och hur den tillägnas.

Begreppet hållbar utveckling är omdiskuterat och både inspirerar och väcker skepsis (Jickling \& Wals, 2008, 2012). Vad undervisning för hållbar utveckling kan innehålla och hur sådan undervisning anordnas har inte bara undersökts i flertalet forskningsstudier (bl. a. Sund, 2015; Rauch \& Steiner, 2013; Madsen, 2013; Öhman, 2008; Vare \& Scott, 2007). Undervisning för hållbar utveckling är också framskrivet i styrdokument för både grund- och gymnasieskola. Skolans uppdrag innebär att arbeta med såväl normer och värden - respekt och omsorg om vår miljö - som med kunskaper om förutsättningarna för en god miljö och en hållbar utveckling (Skolverket, 2011).

Epistemologi är ett filosofiskt problemområde som behandlar frågor om mänsklig kunskap. Sådana frågor handlar om att förstå kunskapens natur. Vad innebär det att ha kunskap? Vad kan vi ha kunskap om? Hur säker är denna kunskap och varifrån kommer den? Intresset för personliga kunskapsteorier, mini-teorier eller vad som inom psykologi, filosofi och utbildningsvetenskap ofta benämns med det engelska begreppet epistemic beliefs, består i hur de relaterar till elevers måluppfyllelse och motivation (Bråten \& Strømsø, 2004; Hofer, 2004; Schommer-Aikins, 2004). Det finns en rik flora internationella studier kring epistemic beliefs och deras betydelse för motivation samt förståelse av s.k. vilda (engelska: wicked, ill-structured) problem, komplexa problem som t. ex. hållbar utveckling (Bråten \& Strømsø, 2004; DeBacker \& Crowson, 2006; Ricco, Schuyten Pierce \& Medinilla, 2010). Man kan även notera att Skolverket (2016) inom sitt uppdrag att sprida forskning framhåller så väl en norsk som en taiwanesisk studie, samt en översiktsstudie av Hofer och Pintrich (1997). Tillsammans med en svensk avhandling från 2018 (Lindfors, 2018) borgar detta för att forskningsfältet börjar uppmärksammas i Sverige 
samt att de resultat som produceras upplevs som praktiknära och relevanta för verksamma lärare.

Det teoretiska ramverket för den föreliggande studien ligger nära Hofer och Pintrich (1997) med en mer filosofisk ansats än Schommer (1990) som även hade med undervisnings- och lärandedimensioner $i$ sitt ramverk. Ett övergripande intresse $\mathrm{i}$ avhandlingen är hur elever orienterar sig i en komplex undervisningskontext, och i det här fallet en transdisciplinär kontext med flera olika intressenter. Det avhandlingen har för avsikt att utforska är vilka dimensioner av personliga kunskapsteorier (epistemic beliefs) som förekommer bland eleverna och om det går att etablera ett samband mellan dessa och elevernas upplevelse av det transdisciplinära undervisningsprojektet. Avhandlingens kunskapsteoretiska intresse baseras på antagandet att elevers personliga teorier om kunskap och kunnande sätts i spel, dels på grund av hur komplexiteten är organiserad i undervisningen, dels på grund av själva ämnets komplexa konstitution, pluralistiska och ibland konfliktartade tolkningsbarhet.

Avhandlingens andra kunskapsobjekt är kopplat till didaktiska frågor $\mathrm{i}$ undervisningens praktik och handlar om lärares UHU-kompetenser. Hur förhåller sig lärare till UHU och hur ser de på sina möjligheter att bedriva sådan undervisning? Två för avhandlingen relevanta tidigare studier i Sverige har intresserat sig för gymnasielärares undervisningstraditioner respektive begreppsliggörande av hållbar utveckling (Borg, Höglund, Gericke, \& Bergman, 2012; 2014).

Med ambitionen att förstå UHU utifrån hur elever förhåller sig till kunskap och transdisciplinärt organiserad undervisning, samt vilka kompetensaspekter bland verksamma lärare inom UHU som framträder, är de övergripande forskningsfrågorna för avhandlingen:

- FF1. Vilka personliga kunskapsteorier kan identifieras bland gymnasieelever involverade i ett transdisciplinärt hållbarhetsprojekt?

- FF2. Vilka dimensioner av lärares hållbarhetskompetenser kan identifieras bland gymnasielärare vid en enskild skola?

- FF3. Hur kan moralisk litteracitet, epistemiska och etiska dimensioner av UHU relateras till konceptualiseringar av kompetens?

\section{Forskningsdesign och metod}

Avhandlingens metodologiska bakgrund är emergent (engelska: emergent design) med abduktiva inslag, vilket betyder att forskningsarbetet har skett med 
växelvis fokus på teori och praktik. Såväl de teoretiska som de empiriska studierna har en explorativ ansats, vilket innebär att de resultat som kommer fram påverkar den fortsatta designen (Given, 2008). Avhandlingen har alltså en explorativ och filosofisk hållning och statistiska analyser kombineras med teoretiska. Jag använder mig av Dohns $(2011 ; 2018)$ metod filosofera med vilket innebär att förutom de mer konventionella användningarna av filosofi i konceptuella redogörelser och empiriska tolkningar, så inbjuds filosofin och epistemologin till dialog med den empiriska analysen om vad kunskap kan tänkas vara och hur den kan inhämtas (Dohn, 2011; 2018; Kotzee 2013). Filosofera med innebär att det reduktiva förhållningssättet till data inom statistisk analys möter ett explikativt analysförfarande, som går bortom eller parallellt med empirin och ger mer kunskap. Det kan sägas motsvara en reflekterande metodologi (Alvesson \& Sköldberg, 2009). Med en övergripande filosofisk ansats och reflekterande metodologi kan avhandlingen anses förhålla sig något friare till insamlade data och ser värdet $\mathrm{i}$ dessa data för att utveckla teori. Metodologin kan leda till nya, kreativa resultat.

För att kunna inhämta kunskap om elevernas personliga teorier om kunskap och kunnande har jag tagit fram ett tvådelat enkätinstrument (SEBTE). Första delen samlar in kunskap om elevernas uppfattningar om kunskap, och kunnande. Den andra delen utvärderar projektets transdisciplinära karaktär. Instrumentet utvecklades genom att tre epistemologiska dimensioner av personliga kunskapsteorier fick utgör ramverket för första delen av enkäten. Dessa dimensioner återfinns i litteraturen: kunskapens struktur, kunskapens ursprung, och kunskapens legitimitet. Instrumentet kontextualiserades och validerades genom tre tidigare använda instrument: Schommer's Epistemological Questionnaire (Schommer, 1990), Epistemic Beliefs Inventory (Schraw, Bendixen, \& Dunkle, 2002), samt Epistemological Beliefs Survey (Wood and Kardash, 2002)och har föregåtts av en serie pilotstudier, främst för att försäkra enkätfrågornas tydlighet.

Empiriska studier med inriktning på lärares förhållningssätt till UHU är begränsade, liksom kvantitativa studier av lärares kompetenser i UHU (Andersson et al., 2013). Målet med den andra empiriska studien i denna avhandling var därför att utforska yrkesverksamma lärares attityder och förhållningssätt till utbildning för hållbar utveckling (UHU) i ett skolutvecklingsprojekt med avsikt att stödja genomförandet av UHU i undervisningsutövning. Ett nytt forskningsinstrument utvecklades för att fånga lärares kompetenser och mäta förhållningssättet till UHU bland gymnasielärare 
i en stor skola i Sverige. Begreppet tillvägagångssätt tolkas här som ett uttryck för lärarkompetens. För att undersöka hur lärare förhåller sig till lärande för hållbar utveckling har ett nytt enkätinstrument tagits fram. Som teoretiskt ramverk för enkätfrågorna vände vi oss till Cebrián och Junyent (2015) som i sin enkätstudie med lärarstudenter identifierade dimensioner av lärande för hållbar utveckling som: kunskap; praktiska förmågor, etiska värden, attityder och känslor. Dessa dimensioner liknar de kompetenser för lärande för hållbar utveckling som tagits fram av OECD (Organisation for Economic Cooperation and Development, 2005; Rychen \& Salganik, 2003). Med antagandet att lärares förhållningssätt till lärande för hållbar utveckling kan säga något om deras undervisningskompetens för hållbar utveckling formulerades 26 frågor med en 6-gradig Likertskala med de två ändpunkterna beskrivna som Inte alls, respektive Ja, absolut. Ett svarsalternativ - Kan ej bedöma - ligger utanför skalan och fyller den funktion att ge ett svarsalternativ så att respondenterna inte börjar hoppa över svar när de stöter på en fråga de av olika skäl inte kan eller vill besvara.

I framtagandet av frågor har även Borg et al. (Borg, Gericke, Höglund \& Bergman, 2012) haft betydelse. Begreppet hållbar utveckling kan tyckas bli prövat i en snävt ekologisk tolkning $i$ enkäten genom att 7 frågor innehåller ordet miljö, 6 natur och 3 natur och miljö. Enkäten prövar inte i första hand hur lärarna definierar hållbar utveckling eller lärande för hållbar utveckling. Däremot är perspektivet ekologisk hållbarhet något som alltsedan miljöundervisningens inträde $\mathrm{i}$ skolan blivit mest etablerat och traditionellt förknippat med hållbarhet. I vissa konceptualiseringar är den ekologiska dimensionen själva förutsättningen för de övriga ekonomiska och sociala dimensionerna.

För att bedöma frågornas validitet genomfördes en första pilotstudie där respondenterna uppmanades kommentera frågor som var otydliga. Efter pilotstudien justerades några frågors formuleringar. Dessa användes i en första pilotstudie med 30 deltagare.

Båda enkätinstrumentens reliabilitet och validitet utvecklas i avsnitten Instrumentation och Research results ovan samt mer specifikt i artikel II och V. Förutom pilotstudier med instrumenten används Cronbachs alpha samt faktoranalys för att bedöma instrumentens reliabilitet. Dessutom är den teoretiska analysen av de empiriska begreppen avgörande för hur väl instrumenten kan fånga dessa (Moss, 1995). Trots att urvalet respondenter är 
ett bekvämlighetsurval, finns det stöd för att se dessa som relevanta (Mullinix, Leeper, Druckman, \& Freese, 2015).

Den teoretiska analysen i den emergenta forskningsdesignen avser att öka tillförlitligheten av den explikativa ansatsen att filosofera med. Med avstamp i de empiriska studiernas resultat utvecklas centrala begrepp genom att föras samman med dessa begrepp inom olika forskningsfält som epistemologi utbildning och psykologi. För att ytterligare stärka validitet och tillförlitlighet $\mathrm{i}$ de teoretiska studierna, har dessa presenterats vid flera forskningskonferenser: den årliga nordiska konferensen för utbildningsvetenskaplig forskning, NERA, (2013, 2014 och 2016), den årliga europeiska konferensen för utbildningsvetenskaplig forskning ECER (2014) och Nordisk forskningskonferens om miljö- och hållbarhetsutbildning som återkommer vartannat år (2016, 2018 och 2021)

\section{Resultat}

I artikel I, A phronesian strategy to education for sustainable development in Swedish school curricula, undersöks begreppet hållbar utveckling i fyra ämnesplaner inom samhällsorientering enligt grundskolans läroplan, Lgr 11. Ämnena samhällskunskap, historia, geografi och religion uppvisar trots sin nära relation, en pluralistisk tolkning av begreppet hållbarhet och dess praktiska betydelse i en undervisningskontext. För att analysera begreppet används Bernard Williams tjocka och tunna begrepp i förhållande till Kotzees world-guidedness och action-guidingness (Kotzee, 2011). Så kallade tjocka begrepp har såväl deskriptivt som värderande innehåll. Tunna begrepp har endast ett värderande innehåll, som till exempel rätt och fel. Begreppet hållbar utveckling kan förstås som ett tjockt begrepp som såväl förhåller sig till och påverkas av något verkligt i världen samt utövar ett rättesnöre för handling. Analysen visar att ämnesplanerna i de fyra SO-ämnena uppvisar olika grader av praktisk kunskap som kan tänkas ha betydelse för en handlingskompetens, men i första hand framträder en mer kognitiv eller analytisk kunskap i ämnesplanerna. Genom att föra in Aristoteles begrepp fronesis eller praktisk vishet föreslås utifrån resultaten en undervisningsstrategi som utgår från kritisk hållning som grund för antagande - justification of belief, vilken i sig blir grunden för handling justification for doing, ett slags handlingskunskap.

Artikel II, Epistemic beliefs and knowledge creation among upper-secondary students in transdisciplinary education for sustainable development tar sin utgångspunkt i en 
undervisningskontext som till sin konstruktion är transdisciplinär och till sitt innehåll handlar om hållbar utveckling. Med transdisciplinär undervisning menas här att den är gränsöverskridande när det gäller skolämnesgränser, men också när det gäller skolans gränser i förhållande till närsamhället och andra intressenter som medskapare av kunskap. Inom ramen för det transdisciplinära undervisningsprojektet deltog 208 gymnasieelever från 14 gymnasieskolor och 2 folkhögskolor som skrev och publicerade en bok om temat Mat. Det kunskapsteoretiska intresset för denna undervisningskontext baseras på antagandet att elevers personliga teorier om kunskap och kunnande, deras epistemic beliefs, är avhängigt både undervisningsinnehållet och undervisningens organisation.

Genom statistisk analys, explorativ faktoranalys (EFA) och multipel regressionsanalys (MRA), kunde både deskriptiva och explanativa resultat erhållas. Fem dimensioner av personliga kunskapsteorier kunde manifesteras genom enkätinstrumentet: transdisciplinär kunskap, kollaborativ kunskap, säker kunskap, enkel kunskap, snabb kunskap. Den transdisciplinära kunskapen ses som komplex, i utveckling och delvis motstridig. Ett slags värderande epistemologi framträder där ett kritiskt förhållningssätt intas i förhållande till expertkunskap. Snabb kunskap har kan i likhet med Schommers lärandedimension snabbt lärande, beskrivas genom uppfattningen att kunskap inhämtas snabbt och utan ansträngning. Den tredje dimensionen, säker kunskap identifierades också av Schommer (1990). Skolan och forskningen ses som arenor för säker kunskap. Kunskap uppfattas som beständig och oföränderlig. Kunskap förmedlas snarare än skapas. Enkel kunskap, förefaller beröra kunskapens struktur. Denna fjärde dimension i faktoranalysen verkar vara en förening av två av Schommers dimensioner, enkel kunskap och medfödd förmåga. Den femte faktorn i analysen är kollaborativ kunskap vilken kan sägas består av både kunskapens struktur och hur den uppstår.

I en efterföljande stegvis multipel regressionsanalys där elevernas upplevelse av det transdisciplinära undervisningsprojektet utgjorde beroendevariabeln, visade sig alla faktorer vara signifikanta oberoende variabler. Kollaborativ och transdisciplinär kunskap tillsammans med säker kunskap är de tre faktorer som är mest signifikanta. Gymnasieprogramtillhörigheten naturvetenskaplig och teknisk utbildning laddar negativt på beroendevariabeln, vilket skulle kunna tyda på att elever på de programmen orienterar sig mindre väl i transdisciplinära projekt. Könstillhörighet man har i föregående modeller haft signifikans, men inte $i$ den avslutande modellen $i$ den stegvisa regressionsanalysen. 
Sammanfattningsvis är det variablerna som motsvarar olika dimensioner av elevers personliga teorier om kunskap och kunnande som har störst inverkan på beroendevariabeln.

Artikel III, Conceptions of ethical competence in relation to action readiness in education for sustainable development, utgörs av en teoretisk studie som undersöker analytiska och normativa dimensioner av etisk kompetens i relation till UHU. Etisk kompetens kan relateras till värdepedagogikens område, vilken kännetecknas av att förgivettagen kunskap om vad som anses vara rätt, fel eller sann, förmedlas inom ramen för moraliska frågor. Om etisk kompetens ska kunna användas inom UHU behöver man närma sig begreppet som ett kritiskt perspektiv, kritisk etisk kompetens. Studien har två syften, att lyfta fram dimensioner av etisk kompetens, och att föra fram handlingsberedvillighet (engelska: action readiness) som ett empiriskt begrepp för framtida studier. Den tolkande analysprocessen består i att studera uttryck för etisk kompetens och guidas av terminologin inom svensk policytext, kunskapsförmedling och fostran.

Nyckelkompetenser inom hållbar utveckling, framförda av OECD (de Haan, 2010) delas in i tre kategorier: användande av interaktiva verktyg, interagera $\mathrm{i}$ socialt heterogena grupper, och självstyrt handlande. De tre kategorierna hålls samman av handlingsperspektivet. Handlingsberedvillighet som empiriskt begrepp motsvaras inte av en given handling i en viss situation utan välkomnar handlingsmöjligheter och växlar fokus till villighet att handla $i$ bemärkelsen inte avstå från att handla. Den pedagogiska idén som stödjer begreppet vilar på föreställningen om att ett engagemang inom hållbarhetsfrågor på ett kritiskt och självreflekterande sätt kan bidra till att eleverna utvecklar etisk kompetens. Det är handlingsberedvilligheten (action readiness) som förenar erfarenhet och handling snarare än förutbestämda regler, normer och sanningsanspråk. Genom att skapa utrymme för dialog och handlingsmöjligheter för eleverna och genom att tillsammans med dem behandla etiska frågor inom UHU genom kritisk reflektion kan etisk kompetens och handlingsberedvillighet ta form.

Artikel IV Philosophizing with transdisciplinarity, relational knowledge and etbics in education for sustainable development består av ett bokkapitel (i O. Franck and C. Osbeck (Eds.) Ethical Literacies and Education for Sustainable Development: Young people, subjectivity, and democratic participation.) Studien tar avstamp i de empiriska resultaten i artikel II och närmar sig idéer om transdisciplinaritet, relationell kunskap och etik inom UHU ur en eklektisk, teoretisk synvinkel. Detta innebär att frågor av epistemologisk, relationell och etisk natur behandlas 
mot bakgrund av undervisning för hållbar utveckling (UHU). Transdisciplinär undervisning i verklighetsrelaterade projekt med externa aktörer antas förbereda elever för att möta epistemisk variation och osäker grund. De relationella och interpersonella undervisningsaktiviteterna får inte begränsas till endast iscensättandet av undervisningen där lärande är ett förgivettagande. I stället behöver undervisningen omfamna värdeundervisning och moralkunskap. Två teorier som understöder det transdisciplinära angreppssättet av globala utmaningar för hållbarhet är systemtänkande och holism. Givet att systemtänkande hänger nära samman med beslutsfattande och handling, kan frågor om hur det mänskliga systemet ska förstås och relateras till det naturliga systemet bli en epistemisk och etiskt viktig uppgift för UHU. Att utveckla kunskap om system och deras inbördes relationer samt överväga sin egen känsla av tillhörighet eller brist på sådan i förhållande till bestämda system är ett viktigt syfte för ESD, epistemiskt och etiskt.

Ett väsentligt perspektiv i studien är Nancy Tuanas (2007) konceptualisering av moralisk litteracitet (engelska: moral literacy). Hennes teoretiska ramverk har en tydlig pedagogisk prägel och består av tre komponenter; etisk sensitivitet, förmåga till etiskt resonemang och moralisk föreställningsförmåga. Dessa komponenter är utvecklingsbara hos elever och Tuana menar att moralisk litteracitet är en komplex förmåga som skolan kan fostra och eleven utveckla, precis som matematisk litteracitet. Moralisk litteracitet förefaller kunna utgöra en del av begreppet hållbarhetskompetens.

Artikel V, Teacher competences in education for sustainable development - the development of a questionnaire instrument utgörs av en kvantitativ, empirisk studie. Under senare år har kompetensbegreppet uppmärksammats inom utbildning för hållbar utveckling (Kramming, 2017; Mochizuki \& Fadeeva, 2010; Mogensen \& Schnack, 2010; Rieckmann, 2012; Wesselink \& Wals, 2011, Wiek, Withycombe \& Redman, 2011). Kompetenser har beskrivits som målet med undervisning för hållbar utveckling, men det begreppet har också kritiserats på grund av sin vacklande teori (Mulder, 2017; Rieckmann, 2012). Trots detta är kompetensbegreppet intressant som ett kunskapsbegrepp som vidgar kunskapsförståelsen till något utöver ämneskunskaper (Nordin, 2012).

Eftersom instrument som mäter lärarkompetens $i$ relation till implementering av UHU förefaller saknas, utvecklades inom ramen för denna studie ett nytt instrument (LUK, eng. TESDC). Flera kompetensmodeller har sitt ursprung i OECD:s DeSeCo-projekt (Cebrián \& Junyent, 2015; Knain, 2005; Mochizuki \& Fadeeva, 2010; Rychen \& Salganik, 2003). I DeSeCo:s 
konceptualisering beskrivs kompetensbegreppet som holistiskt och integrerat, och definitionen har ambitionen att omfatta begreppets hela komplexitet. Utifrån Cebrián och Junyents (2015) ramverk baserat på denna konceptualisering används kompetensaspekterna: kunskap (6 frågor), praktisk förmåga (7 frågor), etiska värden (7 frågor), attityder (4 frågor), känslor (2 frågor). Enkäten besvarades av 183 lärare (se tabell 5) vid en större, svensk gymnasieskola. Enkätfrågorna återfinns på svenska i bilaga $\mathrm{B}$ (Appendix $\mathrm{B}$ ).

Genom explorativ faktoranalys identifierades fyra latenta faktorer: didaktik, motivation, kapacitet och hinder, vilka kan tolkas som olika dimensioner av lärarkompetenser och beredskap för att implementera UHU. Frågorna i varje faktor gjordes om till summavariabler och användes i bivariat analys med bakgrundsvariablerna. Dessa visade inga signifikanta samband. Detta skulle kunna tyda på en gemensam skolkultur som är starkare än bakgrundsfaktorer som ålder, undervisningserfarenhet och ämnestillhörighet. Skolkulturen har dock inte utvärderats i den här studien.

Artikel VI, Focusing on moral literacy and normative competence in education for sustainable development är ett artikelmanus, som syftar till att inleda en syntetisering av de fem genomförda studierna. Här ställs epistemiska och etiska dimensioner i förgrunden eftersom de tidigare studierna visat att just dessa dimensioner kan vara avgörande för hur UHU kan bedrivas i större skala, något som i sin tur medför noggranna överväganden av hur lärandeprocesser kan stöttas. Normativ kompetens undersöks som ett praktiskt-pedagogiskt begrepp. Två filosofer, Nancy Tuana och Linda Zagzebski ger olika bidrag i analysprocessen. Deras moraliska litteracitet (Tuana, 2007) och moraliska teori med ett praktiskt syfte (Zagzebski, 2013) riktar uppmärksamhet mot processer och relationer som är inblandade i att ha skäl att tro något och att ha skäl att inte avstå från att agera.

I en agent-baserad teori kring rationella val utgör individens inre och dess processer det etiska fundamentet tillsammans med icke-etiska faktorer i utvärderingen av det rätta valet, den rätta handlingen. Bättre vore att tala om ett informerat lärande grundat i normativt tänkande och normativ kompetens. Med en undervisning som fokuserar på att eleverna utvecklar ett antal kompetensaspekter snarare än lär in ett visst beteende kan utbildningen enligt Kramming anses vara transformativ snarare än transmissiv (2017). Även Wesselink \& Wals (2011) beskriver det transformativa lärandet som kompetensbaserat, eftersom undervisningen domineras av deltagande och dialog snarare än kunskapsöverföring. Lärandet föreslås vara djupgående och 
innebära ett deltagande fullt ut (Sterling, 2014). Eleverna får möta sig själva som aktörer med ansvar för sin förmåga att delta i denna praktik.

Den etiska tendensen inom undervisning för hållbar utveckling (Öhman \& Östman, 2008) har studerats genom undervisningens följemeningar (Lundqvist \& Östman); lärares selektiva undervisningstraditioner (Sund, 2008) samt etisk kompetens (Osbeck, Franck, Lilja \& Sporre, 2018). Det är exempel på några teman inom UHU som fokuserar normativitet. I sin forskningsöversikt av kompetensforskningen inom UHU har Wiek, Withycombe \& Redman (2011) identifierat ett ramverk bestående av fem nyckelkompetenser för att identifiera komplexa hållbarhetsproblem och finna möjliga lösningar av desamma. I de fyra första nyckelkompetenserna betonas ett kollektivt förhållningssätt till systemtänkande kompetens, föregripande kompetens, normativ kompetens, strategisk kompetens. Den femte kompetensaspekten är mer generell och omnämns som interpersonell kompetens. I Krammings svenska översättning betonas den processorienterade aspekten av kompetenserna genom sammansättningar med tänkande $\mathrm{i}$ alla fyra kompetenser: systemtänkande, framtidstänkande, värdetänkande och strategiskt tänkande (Kramming, 2017), medan interpersonell förmåga översätts direkt. Följande presentation intresserar sig för dimensioner av normativitet inom UHU och undersöker hur begreppet normativ kompetens kan förstås i denna kontext.

Utifrån ett kritiskt realistiskt perspektiv är vår avsikt att teoretiskt tydliggöra begreppet normativ kompetens för att bättre fånga etisk kompetens för hållbar utveckling. Begreppen normativ kompetens och action readiness kan översättas och hanteras som praktisk-pedagogiska begrepp och utgöra de kompetensaspekter som undervisning för hållbar utveckling skulle kunna resultera i. Den praktisk-pedagogiska frågan rör hur normativitet inom UHU kan förstås på ett kreativt sätt så att undervisningspraktiken inte verkar indoktrinerande och inte heller hindras av omöjligheten i ett hitta ett givet svar.

Metodologiskt är denna forskning informerad av kritiskt holistiskt tänkande med hemvist i praktisk filosofi och praktiska dimensioner av rationalitet. Genom att följa det normativa innehållet identifieras värdeladdade premisser och forskningsdesignen tar form. Som en praktisk-pedagogisk plattform tjänar de etiska profiler som Franck (2018) identifierat i läroplanstext.

Kritisk analys i hänseende till epistemiskt och normativt rättfärdigande av handlande inom den normativa domän som hållbarhetsundervisning utgör, kan ur ett filosofiskt pragmatiskt perspektiv presentera en kreativ analys av normativitetsbegreppet. Ett klargörande av normativitetsbegreppet i den 
pedagogiska praktiken och den normativa domänen hållbar undervisning kan stödja introduktionen av begreppet handlingsberedvillighet, action readiness, (Grice \& Franck, 2017), vilket avser överbrygga gapet mellan teori och praktik inom UHU.

Analysprocessen består av ett undersökande av dimensioner av normativitet inom UHU-litteratur och läroplaner som ett meningsskapande och praktiskt fenomen (Wedgwood, 2007). Detta genomförs genom att identifiera dimensionerna och undersöka vilka element som kopplas till begreppet för att utveckla förståelsen av begreppet inom UHU, teoretiskt och praktisktpedagogiskt. I analysen tillämpas Nancy Tuana's (2007) begrepp moralisk litteracitet, bestående av tre komponenter: etisk känslighet, etisk rationaliseringsförmåga och etisk föreställningsförmåga.

Wiek m. fl. (2011) framhåller att hållbarhetskompetenserna sätts i spel med grundläggande kompetenser som kritiskt tänkande. Ett holistiskt kritiskt tänkande torde inkludera reflexivitet, att eleverna ställer frågor om sina egna antaganden och inte avstår från att ifrågasätta det förgivettagna. Den normativa tendensen $\mathrm{i}$ ett holistiskt kritiskt tänkande omfattar ett ifrågasättande av handlingar, varför något utförs. Här behöver sakskäl åberopas och handlingar ges legitimitet. För att det kritiska tänkandet ska anses vara holistiskt behöver det innebära långsiktighet vad gäller konsekvenserna av de beslut som fattas och de handlingar som utförs.

För att det ska få en praktisk betydelse i den iscensatta undervisningen behöver begreppet system-tänkande tas in i undervisningen som ett generellt begrepp. System-tänkandet kan kopplas till studieobjektet, vad är det som studeras, vad det är som lärs in? Det blir också intressant i förhållande till en etisk kompetens en handlingsberedvillighet ska tolkas på olika stadier i utbildningssystemet. Genom att begränsa system-fokus, kan man behålla komplexiteten samtidigt göra det möjligt för eleverna att för hålla sig till och se sig själva som del av eller i relation till. Likaså tidsaspekten - framtidstänkandet. Det är en aspekt som man förväntar sig ökar ju högre upp i utbildningssystemet man kommer.

Den etiska kunskapen för hållbar utveckling förmedlas och utvecklas i praktiken. Den normativa kompetens som eleverna förväntas utvecklas behöver således identifieras av eleven själv och definieras och verkställas av eleven. Det ligger i kompetensbegreppets struktur att dimensioner av handling ska ges utrymme. Därmed är inte sagt att ett visst slags handlingar ska utföras i instrumentell bemärkelse. Skolan kan och bör utveckla ett framtidstänkande, en 
tilltro och en förmåga att tänka framåt, tänka med normativitet om framtiden, men elevens hållbarhetskompetens behöver demonstreras i, för och genom utbildning för hållbar utveckling.

En normativ kompetens för hållbarhet demonstreras genom det empiriska begreppet action readiness, vilket ytterst handlar om att inte avstå från handling. Denna handling ska inte förstås i en omedelbar och reducerad bemärkelse utan omfattar normativa bedömningar, frågor, val och handlingar där vad som är rätt och vilken rätt handling som är rätt samt huruvida en rätt handling är absolut och allomfattande eller vilken grad av tillräcklighet som krävs för att en rätt handling ska förstås som rätt och effektiv ur ett hållbarhetsperspektiv. Det väcker frågor om vad som är kunskap, vad som är analysenheten och vilka skäl som kan anses som epistemologiskt och normativt berättigade.

\section{Diskussion och implikationer}

I den empiriska studien av elevers personliga kunskapsteorier utgjordes de statistiska analyserna i IBM SPSS version 21 av explorativ faktoranalys (EFA) följt av stegvis multipel regressionsanalys (MRA). Den explorativa faktoranalysen handlar $\mathrm{i}$ första hand om att identifiera de underliggande dimensionerna eller faktorerna som utgörs av den samvarians som finns mellan de manifesta variablerna. Explorativ faktoranalys stöder en femfaktoriell lösning: transdisciplinär kunskap, säker kunskap, snabb kunskap, kollaborativ kunskap, enkel kunskap. Namngivandet av dimensionerna knyter an till de teoretiska modellerna av Schommer, Hofer och Pintrich $\mathrm{m}$ fl.

I en efterföljande multipel regressionsanalys undersöktes korrelationen mellan flera olika variabler. De fem faktorerna transformerades till summavariabler och matades in i SPSS som oberoende variabler. Bakgrundsfaktorerna, ålder, programtillhörighet och kön, matades in som dummyvariabler. Beroendevariabeln konstruerades av de utvärderingsfrågor som utgjorde del B i enkäten. Dessa gjordes om till en summavariabel. Genom MRA framkommer vilka oberoende variabler som har en signifikant effekt på den beroende variabeln, vilken utgjordes av projektutvärderingen. Det visar sig att kollaborativ kunskap, transdisciplinär kunskap samt säker kunskap har direkt påverkan på den beroende variabeln som utgörs av elevernas utvärdering av projektet Mat! I den sista modellen, nr 7, visar det sig att faktorn snabb kunskap (elever med uppfattningen att kunskapen kommer till en snabbt eller inte alls), samt bakgrundsvariabeln studieprogram naturvetenskap och teknik laddar negativt på 
projektutvärderingen. Detta skulle kunna tyda på att tron på snabb kunskap har en negativ effekt på hur eleverna orienterar sig $i$ en komplex undervisningssituation om hållbar utveckling. Mängden arbete som krävs av eleven är förmodligen större på grund av att läraren handleder elevens egna initiativ och urval av kunskapsstoff. Resultatet skulle också kunna tyda på att det inom de naturvetenskapliga/tekniska programmen förekommer en kunskapssyn som främjar en tro på att du antingen kan eller inte kan ett ämne, t. ex. matematik. I de tidigare stegen av MRA, när inte alla oberoende variabler ingår, har könstillhörigheten man också signifikans. Den försvinner när ännu fler variabler ingår. Sammanfattningsvis visar dock resultatet att de personliga kunskapsteorierna och inte bakgrundsfaktorerna har störst genomslag.

När det gäller den andra forskningsfrågan om lärares UHU-kompetens visar det sig att de olika kompetensaspekterna som byggde på DeSeCo-ramverket inte avspeglades i faktoranalysen. Istället framträdde fyra dimensioner som motsvarar de bakomliggande faktorer som påverkar hur lärarna svarar på de 26 enkätfrågorna. En slutsats från denna empiriska studie är att de fyra faktorerna skildrar lärares professionella UHU-kompetens, eftersom frågorna tog avstamp i lärare uppfattningar kring UHU. Den dimension eller faktor som benämns didaktik är den största. Huruvida dessa manifesterade dimensioner är allmängiltiga behöver undersökas i ytterligare studier.

I vad mån instrumentet lyckas fånga begreppet undervisningskompetens för lärande för hållbar utveckling kan diskuteras. Trots att antalet faktorer $\mathrm{i}$ analysen empiriskt motiveras av fyra har analysen extraherat områden som kan definieras som ett slags kompetens. Den interna konsistensen inom faktorerna är varierande, från god till måttlig, vilket motiverar en acceptabel validitet och reliabilitet $\mathrm{i}$ instrumentet. Resultatet visar att det finns ett slags säkerhet bland personalen att undervisa $i$ lärande för hållbar utveckling. Här finns det anledning att överväga om det finns andra signifikanta bakgrundsfaktorer som behöver inkluderas i ytterligare utveckling av instrumentet. En sådan faktor är skolkultur.

När det gäller den tredje forskningsfrågan är action readiness ett begrepp som relaterar såväl till individens kompetens i denna stund som för framtida normativa situationer som kräver rätt och tillräcklig handling. Begreppet får i Bernard Williams termer tolkas som ett tjockt begrepp genom sina world-guided eller epistemiska dimensioner vilka $\mathrm{i}$ någon mån korresponderar mot representationer i världen som är öppna för en framtida värld, framtida 
utmaningar och framtida lösningar. Normativ kompetens är nödvändig för och utvecklas genom handlingsdriven pedagogik.

Det hållbara undervisningsparadigmet omfattar förändringar mot holistiska, systembaserade och integrerade förhållningssätt, enligt vilka eleverna förväntas utveckla kompetensaspekter som framtidstänkande och systemtänkande (Kramming, 2017; Rieckmann, 2012). Här kan systemtänkande förstås som en epistemisk ansats som, beroende på sin skala, ramar in större eller mindre komplexa relationer. Framtidstänkande kan förutom det rent epistemiska även sägas omfatta normativa dimensioner av hur saker borde vara och vad som borde göras. För att undvika att elever möter en indoktrinerande UHU (Jickling, 1998) är det av central betydelse att elevers frihet att definiera sitt hållbarhetsproblem och bedöma vilken handling som är möjlig värnas.

Det ramverk för kompetensaspekter för hållbar utveckling som Riekmann (2019) lägger fram uttrycker en moralisk aspekt mer explicit, jämfört med t. ex. Wiek et al. (2011, 2016). Som vägledning för undervisningspraktik och läroplansutveckling förefaller Tuanas (2007) moraliska litteracitet vara relevant att öppna upp för. Etisk sensitivitet, förmåga att resonera etiskt och moralisk föreställningsförmåga är de tre komponenter som utgör ramverket. Tuana lyfter fram att litteracitetsbegreppet är ett komplext begrepp, och som kan beskrivas som ett kontinuum. Elever kan alltså utvecklas utefter detta kontinuum. Dessutom menar Tuana att skolan kan utveckla moralisk litteracitet likaväl som matematisk litteracitet. I en konceptualisering av normativ kompetens som ett integrerat och holistiskt begrepp inom UHU skulle begreppet delvis kunna bygga på Tuanas moraliska litteracitet där etisk medvetenhet, kunskap, emotiva och motivationsskapande aspekter behöver analyseras ytterligare.

Till sist görs följande konklusioner. Forskning inom undervisning för hållbar utveckling behöver utvecklas vidare både empiriskt och teoretiskt. Nya begrepp innebär möjligheter till en ny kritisk blick och förändring. Möjligheter och hinder med den transdisciplinära undervisningen inom UHU behöver utredas vidare och med fler kreativa metoder. Kompetensbegreppet i sin mer öppna och utvidgade konceptualisering är flexibelt nog att fånga hela elevens kunskapspalett, där praktisk och teoretisk kunskap omfamnas och där eleven utvecklar en tilltro till den egna förmågan att ta sig an hållbarhetsutmaningar, och finner såväl empiriska som etiska skäl till att handla. 


\section{References}

Aboytes, J., G., R. \& Barth, M. (2020). Transformative learning in the field of sustainability: A systematic literature review (1999-2019). International Journal of Sustainability in Higher Education, 21(5), 993-1013.

Almers, E. (2013) Pathways to action competence for sustainability-Six themes, The Journal of Environmental Education, 44(2), 116-127

Alvesson, M. \& Sköldberg, K. (2018). Reflexive methodology. New Vistas for Qualitative Research. (3rd ed.). London: SAGE Publications

Andersson, K., Jagers, S., Lindskog, A., \& Martinsson, J. (2013). Learning for the future? Effects of education for sustainable development (ESD) on teacher education students. Sustainability, 5(12), 5135-5152.

Bandura, A. (2018). Toward a psychology of human agency: pathways and reflections. Perspectives on Psychological Science, 13(2), 130-136.

Barmark, M. (2009). Faktoranalys [Factor analysis]. In G. Djurfeldt \&. M Barmark, Statistisk verk.tygsläda 2 - multivariat analys [Statistical toolbox 2 - multivariate analysis] (pp. 69-103). Lund: Studentlitteratur.

Barth, A. (2013). Anti-Naturalism: The role of non-empirical methods in philosophy. History and Philosophy of Logic, 34(3), 196-206.

Barth, M., Godemann, J., Rieckmann, M., \& Stoltenberg, U. (2007). Developing key competencies for sustainable development in higher education. International Journal of Sustainability in Higher Education, 8(4), 416-430.

Barth, M, \& Michelsen, G. (2013). Learning for change: An educational contribution to sustainability science. Sustainability Science, 8(1), 103-119.

Barzilai, S., \& Weinstock, M. (2015). Measuring epistemic thinking within and across topics: A scenario-based approach. Contemporary Educational Psychology, 42, 141-158.

Beckett, S. (2012). Holistic competence. Putting judgement first. In Illeris, K. (Ed). International perspectives on competence development developing skills and capabilities. London: Taylor and Francis, pp 69-82.

Belenky, M. R., Clinchy, B. M., Goldberger, N. R. \& Tarule, J. M., (1986). Women's ways of knowing: The development of self, voice and mind. Lund: Studentlitteratur.

Bertschy, F., Künzli, C., \& Lehmann, M. (2013). Teachers' competencies for the implementation of educational offers in the field of education for sustainable development. Sustainability, 5(12), 5067-5080.

Björklund, S. (2014). Lärande för hållbar utveckling - i förskolan [Education for sustainable development - in preschool]. Lund: Studentlitteratur. 
Blackburn, S. (2016). explication. In The Oxford Dictionary of Philosophy. Oxford University Press.

Blok, V., Gremmen, B., \& Wesselink, R. (2015). Dealing with the wicked problem of sustainability: The role of individual virtuous competence. Business \& Professional Ethics Journal, 34(3), 297-327.

Borg, C., Gericke, N., Höglund, H., \& Bergman, E. (2012). The barriers encountered by teachers implementing education for sustainable development: discipline bound differences and teaching traditions. Research in Science \& Technological Education, 30(2), 185 207

Borg, C., Gericke, N., Höglund, H., \& Bergman, E. (2014). Subject- and experience-bound differences in teachers' conceptual understanding of sustainable development. Environmental Education Research, 20(4), 526-551.

Breiting, S., \& Mayer, M. (2014). Quality criteria for ESD schools: Engaging whole schools in education for sustainable development. In R. Jucker \& R. Mathar (Eds) Schooling for Sustainable Development in Europe (Schooling for Sustainable Development, pp. 31-46). Cham: Springer International Publishing.

Breiting, S., \& Mogensen, F. (1999). Action competence and environmental education. Cambridge Journal of Education, 29(3), 349-353.

Bromme, R., Pieschl, S., \& Stahl, E. (2010). Epistemological beliefs are standards for adaptive learning: A functional theory about epistemological beliefs and metacognition. Metacognition and Learning, 5(1), 7-26.

Bråten, I. (2010). Personal epistemology in education: Concepts, issues, and implications. In E. Baker, B. McGaw, \& P. Peterson (Eds.), International encyclopedia of education (Vol. 5, pp. 211-217). Oxford: Elsevier.

Bråten, I., Ferguson, L., Anmarkrud, Ø., Strømsø, H., \& Brandmo, C. (2014). Modeling relations between students' justification for knowing beliefs in science, motivation for understanding what they read in science, and science achievement. International Journal of Educational Research, 66, 1-12.

Bråten, I., Gil, L., Strømsø, H., I., \& Vidal-Abarca, E. (2009). Personal epistemology across cultures: Exploring Norwegian and Spanish university students' epistemic beliefs about climate change. Social Psychology of Education, 12(4), 529-560.

Bråten, I., \& Strømsø, H. (2004). Epistemological beliefs and implicit theories of intelligence as predictors of achievement goals. Contemporary Educational Psychology, 29(4), 371-388.

Buehl, M., \& Alexander, P. (2001). Beliefs about academic knowledge. Educational Psychology Review, 13(4), 385-418.

Buehl, M., \& Alexander, P. (2005). Motivation and performance differences in students' domain-specific epistemological belief profiles. American Educational Research Journal, 42(4), 697-726.

Burford, G., Hoover, E., Velasco, I., Janoušková, S., Jimenez, A., Piggot, G., \& Podger, D. (2013). Bringing the 'missing pillar' into sustainable development goals: Towards intersubjective values-based indicators. Sustainability, 5(7), 3035-3059. 
Bürgener, L., \& Barth, M. (2018). Sustainability competencies in teacher education: Making teacher education count in everyday school practice. Journal of Cleaner Production, 174, 821 826.

Bäckstrand, K. (2003). Civic science for sustainability: reframing the role of experts, policymakers and citizens in environmental governance. Global environmental politics, 3(4), pp. 2441.

Cameron, R. (2009). A sequential mixed model research design: Design, analytical and display issues. International Journal of Multiple Research Approaches, 3(2), 140-152.

Cebrián, G., \& Junyent, M. (2015). Competencies in education for sustainable development: Exploring the student teachers' views. Sustainability 7(3), 2768-2786.

Cebrián, G., Junyent, M., \& Mulà, I. (2020). Competencies in education for sustainable development: Emerging teaching and research developments. Sustainability, 12(2), 579.

Clarebout, G., Elen, J., Luyten, L., \& Bamps, H. (2001). Assessing epistemological beliefs: Schommer's questionnaire revisited. Educational Research and Evaluation: An International Journal on Theory and Practice, 7(1), 53-77.

Claxton, G. (2009). Cultivating positive learning dispositions. In H. Daniels, H. Lauder \& J. Porter, (Eds) Educational theories, cultures and learning: A critical perspective. critical perspectives on education. Abingdon, Oxon; New York, NY: Routledge, pp. 177-187.

Creswell, J. (2007). Qualitative inquiry \& research design: Choosing among five approaches (2nd ed.). Thousand Oaks: SAGE.

Dahl, T. (2019). Prepared to teach for sustainable development? Student teachers' beliefs in their ability to teach for sustainable development. Sustainability, 11(7), 1993.

Darbellay, F. (2015). Rethinking inter- and transdisciplinarity: Undisciplined knowledge and the emergence of a new thought style. Futures, 65, 163-174.

DeBacker, T., \& Crowson, H. (2006). Influences on cognitive engagement: Epistemological beliefs and need for closure. British Journal of Educational Psychology, 76(3), 535-551.

DeBacker, T. K., Crowson, H. M, Beesley, A. D., Thoma, S. J., \& Hestevold, N. L. (2008). The challenge of measuring epistemic beliefs: an analysis of three self-report instruments. The Journal of Experimental Education, 76(3), 281-312.

De Haan, G. (2010). The development of ESD-related competencies in supportive institutional frameworks. International Review of Education, 56(2), 315-328.

Dohn, N., B. (2011). Roles of epistemology in investigating knowledge: 'Philosophizing with'. Metaphilosophy, 42(4), 431-450.

Dohn, N., B. (2018). 'Philosophizing with' - a role for philosophy as dialogue partner, exemplified within the learning field. Communication \& Language at Work, 5(1), 3-17

Duell, O., \& Schommer-Aikins, M. (2001). Measures of people's beliefs about knowledge and learning. Educational Psychology Review, 13(4), 419-449.

Elby, A. (2009). Defining personal epistemology: A response to Hofer \& Pintrich (1997) and Sandoval (2005). The Journal of the Learning Sciences, 18(1), 138-149. 
Elby, A., \& Hammer, D. (2001). On the substance of a sophisticated epistemology. Science Education, 85 (3), 554-567.

Elen, J., Stahl, E., Bromme, R., \& Clarebout, G. (2011). Introduction. In J. Elen, E. Stahl, R. Bromme, \& G. Clarebout (Eds.) Links Between Beliefs and Cognitive Flexibility: Lessons Learned. Dordrecht: Springer, 1-5.

Ellström, P.-E., \& Kock, H. (2009). Competence development in the workplace - Concepts, strategies and effects. In K. Illeris (Ed.), International perspectives on competence development: developing skills and capabilities. New York: Routledge, 34-54.

European Commission. (2018). Council Recommendation on Key Competencies for Lifelong Learning. Available online: https://ec.europa.eu/education/education-in-the-eu/councilrecommendation-on-key-competences-for-lifelong-learning en (accessed on 27 July 2021).

Franck, O. (2017). Varieties of conceptions of ethical competence and the search for strategies of assessment in ethics education: A critical analysis. In Franck, O. (Ed): Assessment in ethics education - A case of national tests in religious education. Cham: Springer pp 13-54.

Garcia, M., Junyent, M., \& Fonolleda, M. (2017). How to assess professional competencies in Education for Sustainability? International Journal of Sustainability in Higher Education, 18(5), 772-797.

Gervais, J. (2016). The operational definition of competency-based education. Journal of Competency-Based Education, 1(2), 98-106.

Given, L., M. (Ed). (2008). Emergent design. The Sage Encyclopedia of Qualitative Research Methods. Thousand Oaks: SAGE Publications, Inc.

Golding, C. (2015). The community of inquiry: Blending philosophical and empirical research. Studies in Philosophy and Education, 34(2), 205-216.

Gonczi, A., \& Hager, P. (2010) The Competency Model. International Encyclopedia of Education, 8, 403-410. Oxford: Elsevier

Greene, J., A, Azevedo, R., \& Torney-Purta, J. (2008). Modeling Epistemic and Ontological Cognition: Philosophical Perspectives and Methodological Directions. Educational Psychologist, 43(3), 142-160.

Greene, J., Cartiff, B., \& Duke, R. (2018). A Meta-Analytic Review of the Relationship Between Epistemic Cognition and Academic Achievement. Journal of Educational Psychology, 110(8), 1084-1111.

Greene, J., A., Sandoval, W., A., \& Bråten, I. (2016). Handbook of Epistemic Cognition (Educational Psychology Handbook). London. Routledge.

Grice, M., \& Franck, O. (2017). Conceptions of ethical competence in relation to action readiness in education for sustainable development. Reflective Practice. 18(2), 256-267.

Guimarães, M., Pohl, C., Bina, O., \& Varanda, M. (2019). Who is doing inter- and transdisciplinary research, and why? An empirical study of motivations, attitudes, skills, and behaviours. Futures, 112. 
Guo, J., Hu, X., Marsh, H. W., \& Pekrun, R. (2021). Relations of epistemic beliefs with motivation, achievement, and aspirations in science: Generalizability across 72 societies. Journal of Educational Psychology, doi: http:/ /dx.doi.org/10.1037/edu0000660

Hager, P., \& Beckett, D. (1995). Philosophical underpinnings of the integrated conception of competence. Educational Philosophy and Theory, 27(1), 1-24.

Hager, P., \& Gonczi, A. (1996). What is competence? Medical Teacher, 18(1), 15-18.

Hillbur, P., Ideland, M., \& Malmberg, C. (2016). Response and responsibility: Fabrication of the eco-certified citizen in Swedish curricula 1962-2011. Journal of Curriculum Studies, $48(3), 409-426$.

Hofer, B. (2004). Exploring the dimensions of personal epistemology in differing classroom contexts: Student interpretations during the first year of college. Contemporary Educational Psychology, 29(2), 129-163.

Hofer, B. (2016) Epistemic Cognition as a Psychological Construct: Advancements and Challenges. In I. Bråten, J-, A. Greene, \& J. Sandoval (Eds). Handbook of Epistemic Cognition. London: Routledge pp 19-38.

Hofer, B., \& Pintrich, P. (1997). The development of epistemological theories: Beliefs about knowledge and knowing and their relation to learning. Review of Educational Research, 67(1), 88-140.

Holma, K., \& Hyytinen, H. (2015). The philosophy of personal epistemology. Theory and Research in Education, 13(3), 334-350.

Illeris, K. (2004). Transformative learning in the perspective of a comprehensive learning theory. Journal of Transformative Education, 2(2), 79-89.

IPCC (2021) Climate Change 2021: The Physical Science Basis. Contribution of Working Group I to the Sixth Assessment Report of the Intergovernmental Panel on Climate Change [Masson-Delmotte, V., P. Zhai, A. Pirani, S. L. Connors, C. Péan, S. Berger, N. Caud, Y. Chen, L. Goldfarb, M. I. Gomis, M. Huang, K. Leitzell, E. Lonnoy, J. B. R. Matthews, T. K. Maycock, T. Waterfield, O. Yelekçi, R. Yu and B. Zhou (Eds.)]. Cambridge University Press. In Press.

Jensen, B., B., \& Schnack, K. (1997). The action competence approach in environmental education. Environmental Education Research, 12(3-4), 471-486.

Jickling, B. (1994). Why I don't want my children to be educated for sustainable development. The Trumpeter, 11(3), 114.

Jickling, B., \& Wals, A. (2008). Globalization and Environmental Education: Looking beyond Sustainable Development. Journal of Curriculum Studies, 40(1), 1-21.

Jickling, B., \& Wals, A. E. (2012). Debating education for sustainable development 20 years after Rio. Journal of Education for Sustainable Development, 6(1), 49-57.

Kammerer, Y., Bråten, I., Gerjets, P., \& Strømsø, H., I. (2013). The role of internet-specific epistemic beliefs in laypersons' source evaluations and decisions during web search on a medical issue. Computers in Human Behavior, 29(3), 1193-1203.

King, P. M., \& Kitchener, K. S. (1994). Developing reflective judgment: understanding and promoting intellectual growth and critical thinking in adolescents and adults. San Francisco: Jossey-Bass Inc. 
Kitchener, R. (2002). Folk epistemology: An introduction. New Ideas in Psychology, 20(2), 89105.

Kitchner, K. (1983). Cognition, metacognition, and epistemic cognition. Human Development, 26(4), 222-232.

Klenk, N., \& Meehan, K. (2015). Climate change and transdisciplinary science: Problematizing the integration imperative. Environmental Science \& Policy, 54, 160-167.

Knain, E. (2005). Definiering og valg av kompetanser [Definition and selection of competences] - DeSeCo. Norsk Pedagogisk Tidsskrift [Norwegian Educational Journal] 89(1), 125-134.

Kopnina, H. (2020). Education for the future? Critical evaluation of education for sustainable development goals. The Journal of Environmental Education, 51(4), 280-291.

Kopnina, H., \& Meijers, F. (2014). Education for sustainable development (ESD). International Journal of Sustainability in Higher Education, 15(2), 188-207.

Kotzee, B. (2011). Education and thick epistemology. Educational Theory, 61(5), 549-564.

Kotzee, B. (2013). Introduction: Education, Social Epistemology and Virtue Epistemology. Journal of Philosophy of Education, 47(2), 157-167.

Kotzee, B. (2016). Learning How. Journal of Philosophy of Education, 50(2), 218-232.

Kramming, K. (2017). Miljökollaps eller hållbar framtid? Hur gymnasieungdomar uttrycker sig om miljöfrågor [Environmental collapse or sustainable futures? How young people in upper secondary school express themselves about environmental issues]. Geographica, 13. Uppsala university. Doctoral thesis.

Læssøe, J. (2010). Education for sustainable development, participation, and socio-cultural change. Environmental Education Research, 16(1), 39-57.

Laurie, R., Nonoyama-Tarumi, Y., McKeown, R., \& Hopkins, C. (2016). Contributions of education for sustainable development (ESD) to quality education: A synthesis of research. Journal of Education for Sustainable Development, 10(2), 226-242.

Leal Filho, W., Raath, S., Lazzarini, S., Vargas, V. R., De Souza, L., Anholon, R., Quelhas, O. L. G., Haddad, R., Klavins, M. \& Orlovic, V.L. (2018). The role of transformation in learning and education for sustainability. Journal of Cleaner Production, 199, 286-295.

Lee, C. M., and M. J. Taylor. (2013). Moral education trends over 40 years: A content analysis of the Journal of Moral Education (1971-2011). Journal of Moral Education 42(4), 399-429.

Lindfors, M. (2018). 'Kunskap är vad du vet, och vet du inte kan du alltid googla!' Elevers epistemic beliefs i naturvetenskaplig undervisningskontext ["Knowledge is what you know, and if you don't know, you can always google it!" Students' epistemic beliefs in a science teaching context.] Department of Science and Mathematics Education. Umeå university. 2018. Doctoral thesis.

Lönngren, J., \& Van Poeck, K. (2020). Wicked problems: A mapping review of the literature. International Journal of Sustainable Development and World Ecology, 1-22.

Lotz-Sisitka, H. (2017). Education and the Common Good. In B. Jickling and S. Sterling (Eds.) Post-Sustainability and Environmental Education. Cham: Springer International Publishing, 63-76 
Lotz-Sisitka, H., Wals, A., E., J., Kronlid, D., \& McGarry, D. (2015). Transformative, transgressive social learning: rethinking higher education pedagogy in times of systemic global dysfunction. Current Opinion in Environmental Sustainability, 16, 73-80.

Lum, G. (2013). Competence: A tale of two constructs. Educational Philosophy and Theory, 45(12), 1193-1204.

Lundegård, I., \& Caiman, C. (2019). Didaktik för naturvetenskap och hållbar utveckling Fem former av demokratiskt deltagande [Education for science and sustainable development - Four forms of democratic participation]. Nordina: Nordic Studies in Science Education, 15(1), 38-53.

Lykke, N. 2010. Feminist Studies: A Guide to Intersectional Theory, Methodology and Writing. London: Routledge.

MacIntyre, T., Lotz-Sisitka, H., Wals, A.E.J., Vogel, C., \& Tassone, V.C. (2018). Towards transformative social learning on the path to 1.5 degrees. Current Opinion in Environmental Sustainability, 31, 80-87.

Madsen, K. (2013). Unfolding education for sustainable development as didactic thinking and practice. Sustainability. 5(9), 3771-3782.

Maggioni, L., \& Parkinson, M. M. (2008). The role of teacher epistemic cognition, epistemic beliefs and calibration in instruction. Educational Psychology Review, 20, 445-461.

Mason, L., Boscolo, P., Tornatora, M., C., \& Ronconi, L. (2013). Besides knowledge: A crosssectional study on the relations between epistemic beliefs, achievement goals, self-beliefs, and achievement in science. Instructional Science, 41(1), 49-79.

Mathar, R. (2014). A Whole school approach to sustainable development: Elements of education for sustainable development and students' competencies for sustainable development. In R. Jucker \& R. Mathar (Eds.) Schooling for Sustainable Development in Europe (pp. 15-30). Cham: Springer International Publishing.

Michelsen, G., Adomßent, M., Martens, P., \& Von Hauff, M. (2016). Sustainable Development - Background and Context. In H. Heinrichs, P. Martens, G. Michelsen, \& A. Wiek (Eds.) Sustainability Science (pp. 5-29). Dordrecht: Springer.

Miller, J. P. (1986). Atomism, pragmatism, holism. Journal of Curriculum and Supervision, 1(3), 175-196.

Mochizuki, Y., \& Fadeeva, Z. (2010). Competences for sustainable development and sustainability: significance and challenges for ESD. International Journal of Sustainability in Higher Education, 11(4), 391 - 403.

Mogensen, F., \& Schnack, K. (2010). The action competence approach and the 'new' discourses of education for sustainable development, competence and quality criteria. Environmental Education Research, 16(1), 59-74.

Molina-Motos, D. (2019). Ecophilosophical principles for an ecocentric environmental education. Education Sciences, 9(1), 37.

Moss, P. (1995). Themes and variations in validity theory. Educational Measurement, Issues and Practice, 14(2), 5-13. 
Muis, K., Bendixen, L., \& Haerle, F. (2006). Domain-generality and domain-specificity in personal epistemology research: Philosophical and empirical reflections in the development of a theoretical framework. Educational Psychology Review, 18(1), 3-54.

Muis, K., Pekrun, R., Sinatra, G., Azevedo, R., Trevors, G., Meier, E., \& Heddy, B. (2015). The curious case of climate change: Testing a theoretical model of epistemic beliefs, epistemic emotions, and complex learning. Learning and Instruction, 39, 168-183.

Mulder, M. (2017). Competence-based Vocational and Professional Education (Vol. 23, Technical and Vocational Education and Training: Issues, Concerns and Prospects). Cham: Springer International Publishing.

Mulder, M., \& Winterton, J. (2016). Introduction. In Competence-based Vocational and Professional Education (Technical and Vocational Education and Training: Issues, Concerns and Prospects, pp. 1-43). Cham: Springer International Publishing.

Mullinix, K., Leeper, T., Druckman, J., \& Freese, J. (2015). The generalizability of survey experiments. Journal of Experimental Political Science, 2(2), 109-138.

Murphy, K. (2012). The social pillar of sustainable development: A literature review and framework for policy analysis. Science, Practice, \& Policy, 8 (1), 15-29.

Nordén, B. (2018). Transdisciplinary teaching for sustainable development in a whole school project. Environmental Education Research, 24(5), 663-677.

Nordin, A. (2012). Kunskapens politik: En studie av kunskapsdiskurser i svensk och europeisk utbildningspolicy [The politics of knowledge - A study of knowledge discourses in Swedish and European education policy] (Linnaeus University dissertations; 97). Växjö: Linnaeus University Press. Doctoral thesis.

Nordin, A., \& Sundberg, D. (2021). Transnational competence frameworks and national curriculum-making: The case of Sweden. Comparative Education, 57(1), 19-34.

Nussbaum, M. C. (2010). Not for Profit - Why democracy needs the bumanities. Princeton and Oxford: Princeton university press.

OECD (Organisation for Economic Co-operation and Development). (2005). The definition and selection of key competencies. Paris: OECD. http://www.oecd.org/pisa/35070367.pdf. (accessed 29 June 2021)

Öhman, J. (2008). Environmental ethics and democratic responsibility- a pluralistic approach to ESD. In Johan Öhman (Ed.), V alues and democracy in education for sustainable development: contributions from Swedish research. Malmö: Liber. (pp. 17-32)

Öhman, J., \& Sund, L. (2021). A didactic model of sustainability commitment. Sustainability, 13(6), 3083.

Öhman, J., \& Öhman, M. (2013). Participatory approach in practice: An analysis of student discussions about climate change. Environmental Education Research, 19(3), 324-341.

Öhman, J., \& Östman, L. (2008). Clarifying the ethical tendency in education for sustainable development practice: A Wittgenstein-inspired approach. Canadian Journal of Environmental Education, 13(1), 57-72. 
Öhman, J., \& Östman, L. (2019). Different teaching traditions in environmental and sustainability education. In K. VanPoeck, L. Östman, \& J. Öhman (Eds) Sustainable Development Teaching (1st ed., pp. 70-82). Routledge.

Olsson, D., Gericke, N. \& Chang Rundgren, S. (2016). The effect of implementation of education for sustainable development in Swedish compulsory schools - assessing pupils' sustainability consciousness. Environmental Education Research, 22(2), 176-202.

Osbeck, C., Franck, O., Lilja, A., \& Sporre, K. (2018). Possible competences to be aimed at in ethics education - Ethical competences highlighted in educational research journals. Journal of Beliefs and V alues, 39(2), 195-208.

Osborn, D. (2013). Commentary: Building on Rio 20 To Spur Action for Sustainable Development. Environment: Science and Policy for Sustainable Development, 55(3), 3-13.

Perry, W. P. (1968). Forms of intellectual and ethical development in the college years - a scheme. New York: Holt, Rinehart and Winston, Inc.

Persson, L., Lundegård, I., \& Wickman, P. (2011). Worry becomes hope in education for sustainable development - an action research study at a secondary school. Utbildning \& Demokrati [Education \& Democracy], 20(1), 123-144.

Ponce, O., \& Pagán-Maldonado, N. (2015). Mixed methods research in education: Capturing the complexity of the profession. International Journal of Educational Excellence, 1(1), 111135.

Popa, F., Guillermin, M., \& Dedeurwaerdere, T. (2015). A pragmatist approach to transdisciplinarity in sustainability research: From complex systems theory to reflexive science. Futures: The Journal of Policy, Planning and Futures Studies, 65, 45-56.

Rauch, F., \& Steiner, R. (2013). Competences for education for sustainable development in teacher education. c ep s journal, 3, 9-24.

Rest, J. (1986). Moral development: Advances in research and theory. New York: Praeger.

Richter, T. (2011). Cognitive flexibility and epistemic validation in learning from multiple texts. In J. Elen, E. Stahl, R. Bromme, \& G. Clarebout (Eds.) Links Between Beliefs and Cognitive Flexibility: Lessons Learned (pp. 125-140). Dordrecht: Springer Netherlands.

Ricco, R., Schuyten P., S., \& Medinilla, C. (2010). Epistemic beliefs and achievement motivation in early adolescence. The Journal of Early Adolescence, 30(2), 305-340.

Rieckmann, M. (2012). Future-oriented higher education: Which key competencies should be fostered through university teaching and learning? Futures: The Journal of Policy, Planning and Futures Studies, 44(2), 127-135.

Rieckmann, M. (2018). Learning to transform the world: key competencies in Education for Sustainable Development. In A. Leicht, J. Heiss, \& W. J. Byun (Eds.) Issues and Trends in Education for Sustainable Development, UNESCO: Paris, France, 39-60

Rittel, H., \& Webber, W. (1973). Dilemmas in a general theory of planning. Policy Sciences, $4(2), 155-169$.

Romm, N., R., A. (1998). Interdisciplinary practice as reflexivity. Systemic Practice and Action Research, 11(1), 63-77. 
Rudsberg, K. \& Öhman, J. (2010). Pluralism in practice - experiences from Swedish evaluation, school development and research. Environmental Education Research, 16(1), 115131.

Ryan, M. P. (1984). Monitoring text comprehension: individual differences in epistemological standards. Journal of Educational Psychology, 76, 248-258.

Rychen, D., S., \& Salganik, L., H. (2003). Key Competencies for a successful life and a well-functioning society. Gottingen: Hogrefe \& Huber

Schneider, F., Giger, M, Harari, N., Moser, S., Oberlack, C., Providoli, I., Schmid, Le., Tribaldos, T., Zimmermann, A. (2019). Transdisciplinary co-production of knowledge and sustainability transformations: Three generic mechanisms of impact generation. Environmental Science \& Policy, 102, 26-35.

Schommer, M. (1990). Effects of beliefs about the nature of knowledge on comprehension. Journal of Educational Psychology, 82(3), 498-504.

Schommer, M. (1993). Epistemological development and academic performance among secondary students. Journal of Educational Psychology, 85(3), 406-411.

Schommer-Aikins, M. (2004). Explaining the epistemological belief system: Introducing the embedded systemic model and coordinated research approach. Educational Psychologist, 39(1), 19-29.

Schommer-Aikins, M. 2008. Applying the theory of an epistemological belief system to the investigation of students' and professors' mathematical beliefs. In M., S. Khine (Ed.) Knowing, knowledge, and beliefs: Epistemological studies across diverse cultures (pp. 303-323). New York, NY: Springer-Verlag.

Schommer, M., \& Walker, K. (1995). Are epistemological beliefs similar across domains? Journal of Educational Psychology, 87(3), 424-432.

Schraw, G., Bendixen, L. D., \& Dunkle, M. E. (2002). Development and validation of the epistemic belief inventory (EBI). In B. K. Hofer \& P. R. Pintrich (Eds.). Personal epistemology: the psychology of beliefs about knowledge and knowing. (pp.261-271).

Skolverket [Swedish National Agency for Education]. (2002). Hallbar utveckling $i$ skolan [Sustainable development in School]. S-M Ewert AB. Stockholm.

Skolverket [Swedish National Agency for Education]. (2011). Curriculum for the compulsory school, preschool class and the recreation centre. Stockholm: Skolverket.

Skolverket [Swedish National Agency for Education]. (2016). Elevers syn på kunskap viktig för lärandet [Students' conceptions of knowledge important for learning]. https://www.skolverket.se/skolutveckling/forskning-och-utvarderingar/artiklar-omforskning/elevers-syn-pa-kunskap-viktig-for-larandet\#hKunskapssynpaverkarsjalvfortroendet (Accessed 20 March 2017)

Sohl, S. (2014). Youths' political efficacy: Sources, effects and potentials for political equality. Örebro studies in political science, 37. Örebro University. Doctoral thesis.

Spiro, R., Feltovich, P., Coulson, R., Graesser, C., Gholson, Barry, \& Houston, David. (1996). Two epistemic world-views: Prefigurative schemas and learning in complex domains. Applied Cognitive Psychology, 10(7), 51-61. 
Sporre, K. (2017). Global responsibilities and ethics education: To be assessed and if so how?, In Franck, O. (ed): Assessment in Ethics Education - A Case of National Tests in Religious Education. Cham: Springer, pp 115-144.

Sterling, S. (2011) Transformative learning and sustainability: Sketching the conceptual ground. Learning and Teaching in Higher Education, 5, 17-33.

Sterling, S. (2014). Separate tracks or real synergy? Achieving a closer relationship between education and SD, post-2015. Journal of Education for Sustainable Development, 8(2), 89-112.

Stickney, J., \& Skilbeck, A. (2020). Problematising 'transformative' environmental education in a climate crisis. Journal of Philosophy of Education, 54(4), 791-806.

Sund, L. (2014) Om global etik i miljö- och hällbarbetsundervisningens policy och praktik. [On global ethics in environmental and sustainability education policy and practice].

Sund, P. (2008). Att urskilja selektiva traditioner i miljöundervisningens socialisationsinnebåll implikationer för undervisning för hallbar utveckling [Discerning selective traditions in the socialization content of environmental education implications for education for sustainable development . Mälardalen University Press Dissertations. Doctoral thesis.

Sund, P. (2015). Experienced ESD-schoolteachers' teaching- an issue of complexity. Environmental Education Research, 21(1), 24-44.

Sund, P., \& Gericke, N. (2021). More than two decades of research on selective traditions in environmental and sustainability education-Seven functions of the concept. Sustainability 13(12), 6524.

Tuana, N. (2007), Conceptualizing moral literacy, Journal of Educational Administration, 45(4), 364-378.

UN (2020). Decade of action. Retrieved February $14^{\text {th }} 2021$ https://www.un.org/sustainabledevelopment/decade-of-action/

UN General Assembly (2015), Transforming our world: the 2030 Agenda for Sustainable Development, $21 \quad$ October 2015, A/RES/70/1, available at: https://www.refworld.org/docid/57b6e3e44.html [accessed 20 June 2021]

UNECE (2011), Learning for the future, competencies in education for sustainable development. Report of the United Nations Economic Commission for Europe, Steering Committee on Education for Sustainable Development, ECE/CEP/AC.13/2011/6. https://unece.org/fileadmin/DAM/env/esd/6thMeetSC/Learning $\% 20$ for $\% 20$ the $\% 20$ Future_\%20Competences $\% 20$ for $\% 20$ Educators $\% 20$ in $\% 20$ ESD/ece.cep.ac. 13.2011 .6 \%20ADVANCED\%20COPY.pdf (accessed on 5 August 2021)

UNECE (2012). Learning for the future, competencies in education for sustainable development. Report of the United Nations Economic Commission for Europe, Steering Committee on Education for Sustainable Development. Available online: https://unece.org/DAM/env/esd/ESD Publications/Competences Publication.pdf (accessed on 29 July 2021)

UNESCO (United Nations Educational, Scientific and Cultural Organisation). (1996). Learning: the treasure within. Education for the 21st century. Delors Report. Paris: UNESCO. 
UNESCO. (2006). Framework for the UNDESD international implementation scheme. http://unesdoc.unesco.org/images/0014/001486/148650E.pdf.

UNESCO (2018). What is education for sustainable development? (accessed on 13 June 2021) https://en.unesco.org/themes/education-sustainable-development

Van Poeck, K. (2019). Environmental and sustainability education in a post-truth era. An exploration of epistemology and didactics beyond the objectivism-relativism dualism. Environmental Education Research, 25(4), 472-491.

Varga, A., Kószó, M., F., Mayer, M., \& Sleurs, W. (2007). Developing teacher competences for education for sustainable development through reflection: the environment and school initiatives approach. Journal of Education for Teaching, 33(2), 241-256.

Vare, P., \& Scott, W. (2007). Learning for a Change. Journal of Education for Sustainable Development, 1(2), 191-198.

Vetenskapsrådet [Swedish Research Council] (2017). God forskningssed [Good research practice]. Stockholm: Vetenskapsrådet. https://www.vr.se/english/analysis/reports/ourreports/2017-08-31-good-research-practice.html (retrieved on 1 February 2021)

Wankat, P., \& Oreovicz, F. (1993). Teaching engineering. New York: McGraw Hill.

Wedgwood, R. (2007). The nature of normativity. Oxford: Clarendon Press.

Wesselink, R, \& Wals, A, E. (2011). Developing competence profiles for educators in environmental education organisations in the Netherlands. Environmental Education Research, 17(1), 69-90.

Wiek, A., Withycombe, L., \& Redman, C., L. (2011): Key competencies in sustainability: a reference framework for academic program development, Sustainability Science 6(2), 203218.

Wiek, A., Bernstein, M., J., Foley, R., W., Cohen, M., Forrest, N., Kuzdas, C., Kay, B. \& Withycombe Keeler, L. (2016). Operationalising competencies in higher education for sustainable development. In Barth, Michelsen, Thomas \& Rieckmann (Eds.), Routledge Handbook of Higher Education for Sustainable Development. London: Routledge, pp. 241-260.

Wilhelm, S., Förster, R., \& Zimmermann, A. (2019). Implementing competence orientation: Towards constructively aligned education for sustainable development in university-level teaching-and-learning. Sustainability, 11(7), 1891.

Winberg, T., Hofverberg, A., \& Lindfors, M. (2019). Relationships between epistemic beliefs and achievement goals: Developmental trends over grades 5-11. European Journal of Psychology of Education, 34(2), 295-315.

Wolff, L. (2020). Sustainability Education in Risks and Crises: Lessons from Covid19. Sustainability, 12(12), 5205.)

Wood, P., \& Kardash, C. (2002). Critical elements in the design and analysis of studies of epistemology. In B. K. Hofer \& P. R. Pintrich (Eds.). Personal epistemology: the psychology of beliefs about knowledge and knowing. (pp. 231-260). Retrieved from http://www.eblib.com

World Commission on Environment and Development. (1987). Our common future. Oxford: Oxford University Press. https://digitallibrary.un.org/record/139811 
Young, J., \& Chapman, E. (2010). Generic competency Frameworks: A brief historical overview. Education Research and Perspectives, 37(1), 1-24.

Zagzebski, L. (2013). Moral exemplars in theory and practice. Theory and Research in Education, 11(2), 193-206.

Zagzebski, L. (2017). Exemplarist Moral Theory. New York: Oxford University Press. 



\section{Appendix A. SEBTE questionnaire}

\section{GÖTEBORGS UNIVERSITET}

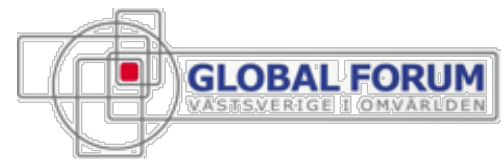

Institutionen för didaktik och

pedagogisk profession

Marie Grice, doktorand

SEBTE 4 mars 2013

\section{UPPFATTNINGAR OM KUNSKAP $O C H$ KUNSKAPSBILDNING - ELEVENKÄT}

Dina svar i denna enkät är ett viktigt underlag för ett forskningsprojekt kring hur elever ser på kunskap. Tack för att du medverkar!

Sätt ETT kryss $\mathbb{Z}$ i EN av rutorna till varje fråga för att markera din åsikt. Hur mycket håller du med om det som står? Inte alls? Markera då med kryss under 1, litet grand markera 2 osv upp till att du helt och hållet håller med: "Ja, absolut" Markera då med kryss under siffran 6 .

(Six-point Likert scale)

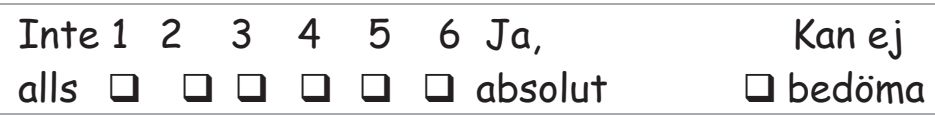

\section{Del A. Dina tankar kring kunskap}

1. Det som är sant idag kommer att vara sant imorgon.

2. Teoretisk kunskap är mer värdefull än praktisk.

3. Lärare skall fokusera på sådant man vet säkert och inte på sådant som forskarna är oense om.

4. Min mesta kunskap får jag genom skolan.

5. Forskning ger kunskap jag kan lita på.

6. Jag får kunskap genom att samarbeta med andra elever.

7. Mycket kunskap får jag utanför skolarbetet.

8. Det är en viktig kunskap att kunna söka och värdera information. 
9. Elever som förstår snabbt klarar sig bäst i skolan.

10. Den kunskap jag får i skolan kan jag lita på gäller.

11. Det finns frågor som experter inte har det rätta svaret på.

12. Kunskap har ett eget värde i sig.

13. Den största visdomen är inte att ha svaret, men att veta hur du får svaret.

14. Det är intressant att fundera på frågor som experter inte är eniga om.

15. Vissa personer har en medfödd förmåga att ta till sig ny kunskap.

16. Om vetenskapsmän arbetar tillräckligt hårt kan de hitta svaren till alla frågor.

17. I skolarbetet koncentrerar jag mig på faktakunskaper.

18. Att arbeta med frågor som vi inte har möjlighet att hitta ett entydigt svar till är bortkastad tid.

19. Jag funderar ofta på om det jag läser är sant.

20. Att jobba en längre tid med ett svårt problem lönar sig bara för smarta elever.

21.Jag lär mig bäst när jag arbetar i projekt med flera skolämnen.

22. Kunskap får jag bäst när jag arbetar med ett skolämne i taget.

23. Jag försöker kombinera den kunskap jag får i olika skolämnen.

24. Kunskap som jag får i ett ämne har jag ofta nytta av i ett annat ämne.

25. De riktigt smarta eleverna behöver inte jobba hårt för att lyckas i skolan.

26. Det är förvirrande att kombinera det jag redan vet om ett ämne med det som står i läroboken.

\section{Del B. Ditt deltagande i Projektet Vår mat!}

1. Har du kunnat använda kunskaper från fler än ett skolämne i ditt projekt?

2. Har projektet gett dig kunskap om möjligheten till hållbar utveckling för samhället?

3. Kommer du kunna ha nytta av det du lärt dig i projektet i andra kurser på ditt gymnasieprogram?

4. Har projektet väckt nya intressen eller idéer inför framtida studier och yrkesliv?

5. Har projektet känts meningsfullt? 


\section{Fyll i några uppgifter om dig själv!}

Kön: man $\square \quad$ kvinna $\square$ Ålder:

Gymnasieprogram:

Kan du tänka dig att ställa upp på en intervju för att komplettera enkäten? Skriv i så fall namn och emailadress eller telefonnummer. Du ingår därmed i ett lotteri med biobiljetter.

Namn:

Email/Telefonnr:

Tack för att du har besvarat enkäten ( 


\section{Appendix B. TESDC questionnaire}

(The six-point Likert scale from SEBTE was used)

1. Det är viktigt att undervisa i och för hållbar utveckling.

2. Lärande för hållbar utveckling kräver speciella undervisningsmetoder.

3. I min undervisning får eleverna kunskap om miljö.

4. I min undervisning får eleverna möjlighet att utveckla omtanke om naturens värden.

5. I min undervisning ges tillfällen till att undersöka naturen i närområdet.

6. Eleverna lär sig hur människan påverkar naturen i min undervisning.

7. Eleverna får möjlighet att använda ett undersökande arbetssätt lärandet för hållbar utveckling.

8. Min undervisning gör det möjligt för eleverna att utveckla miljömedvetenhet.

9. Min undervisning bidrar till att eleverna utvecklar handlingskompetens för hållbar utveckling.

10. Eleverna får i undervisningen reflektera över sitt individuella ansvar för hållbar utveckling.

11. Jag arbetar för att elever och lärare tillsammans ska reflektera över vårt gemensamma ansvar i hållbar utveckling.

12. Det är viktigt att elevernas känslor för hållbar utveckling får utrymme i undervisningen.

13. I min undervisning uppmuntras eleverna att värdesätta natur och miljö.

14. Min undervisning uppmuntrar eleverna till miljövänliga handlingar.

15. Eleverna får kunskap om miljöfrågor i min undervisning.

16. I undervisning för hållbar utveckling samarbetar jag/vi med ett eller flera andra ämnen.

17. Eleverna får möjlighet att sätta in sina faktakunskaper om natur och miljö i ett större sammanhang.

18. Det är meningslöst att ta upp hållbar utveckling i undervisningen.

19. Min rektor stöder mig i att undervisa för hållbar utveckling.

20. Det är svårt att hinna inkludera hållbar utveckling i min undervisning.

21. Jag känner till goda exempel på lärande för hållbar utveckling som jag kan använda i min undervisning.

22. Jag har tillräcklig med kunskaper om hållbar utveckling för att inkludera det i min undervisning.

23. Det är svårt att hitta bra metoder för att undervisa om hållbar utveckling. 
24. Lärande för hållbar utveckling är ett begrepp som har getts plats i de ämnes/kursplaner som jag undervisar utifrån.

25. Jag känner till formuleringarna om hållbar utveckling i läroplanens inledande kapitel.

26. Jag vill lära mig mer om lärande för hållbar utveckling.

Bakgrundsfrågor

Vilket är ditt kön? kvinna $\square$ man $\square \quad$ annat $\square$

Vilken åldersgrupp tillhör du?

19-29 år $\square \quad$ 30-39 år $\square \quad 40-49$ år $\square \quad 50-59$ år $\square \quad 60$ år eller över $\square$

Hur många år har du undervisat?

1-5 år $\square \quad$ 6-10 år $\square \quad$ 11-19 år $\square \quad$ 20-29 år $\square \quad$ 30-39 år $\square \quad 40$ eller mer $\square$

Vilket stadium undervisar du?

Gymnasiet $\square \quad$ Högstadiet $\square \quad$ Mellanstadiet $\square \quad$ Lågstadiet inklusive förskoleklass $\square$

Annat stadium eller flera stadier $\square \ldots \ldots \ldots \ldots .$.

Vilken undervisningskategori stämmer bäst på dig? Sätt endast ETT kryss.

Naturvetenskapliga ämnen: biologi, naturkunskap, miljökunskap, kemi, fysik, teknik, datakunskap och matematik $\square$

Samhällsvetenskapliga ämnen: samhällskunskap, geografi, religion och historia

Språk: moderna språk, engelska, svenska

Yrkesämnen och estetiskt-praktiska ämnen: t.ex. slöjd, bild, musik, hemkunskap

Annan kategori: lärare som undervisar inom två eller flera ämnesgrupper ovan:

Jag har ett uttalat intresse för miljöfrågor:

JA $\square \quad$ NEJ

Jag är engagerad i en miljöorganisation:

JA $\square \quad$ NEJ

Jag har deltagit i någon miljöaktion, $\mathrm{t}$ ex demonstration:

JA $\square \quad$ NEJ 


\section{Appendix C. Oral information to the participants of TESDC}

Lärarenkät - muntlig information i aulan till alla deltagare

Lärarenkät - Lärande för hållbar utveckling - Uddevalla gymnasieskola

Följande enkät ingår i en studie om lärares föreställningar kring lärande för hållbar utveckling. För att få ett tillförlitligt resultat har det betydelse att du deltar.

Resultatredovisning, etik och sekretess

Undersökningens resultat kommer att användas för verksamhetens

kompetensutvecklingsarbete, publiceras i en vetenskaplig artikel samt redovisas på konferenser och seminarier. De medverkande deltar anonymt och det kommer inte vara möjligt att identifiera enskilda personer.

Insamlade data kommer endast att användas inom projektet och kommer således inte att användas i andra sammanhang. Materialet kommer att förvaras på ett sådant sätt att ingen otillbörlig utanför projektet kan få tillgång till det.

Medverkan i studien är frivillig

Ansvariga för enkätstudien:

Marie Grice, Uddevalla gymnasieskola

Anna Mogren, Den Globala Skolan vid Universitet och Högskolerådet.

Helene Grantz, Uddevalla kommun 
Previous publications:

Editors: Kjell Härnqvist and Karl-Gustaf Stukát

1. KARL-GUSTAF STUKÁT Lekskolans inverkan på barns utveckling. Stockholm 1966

2. URBAN DAHLLÖF Skoldifferentiering och undervisningsförlopp. Stockholm 1967

3. ERIK WALLIN Spelling. Factorial and experimental studies. Stockholm 1967

4. BENGT-ERIK ANDERSSON Studies in adolescent behaviour. Project Yg, Youth in Göteborg. Stockholm 1969

5. FERENCE MARTON Structural dynamics of learning. Stockholm 1970

6. ALLAN SVENSSON Relative achievement. School performance in relation to intelligence, sex and home environment. Stockholm 1971

7. GUNNI KÄRRBY Child rearing and the development of moral structure. Stockholm 1971

Editors: Urban Dahllöf, Kjell Härnqvist and Karl-Gustaf Stukát

8. ULF P. LUNDGREN Frame factors and the teaching process. A contribution to curriculum theory and theory on teaching. Stockholm 1972

9. LENNART LEVIN Comparative studies in foreignlanguage teaching. Stockholm 1972

10. RODNEY ÅSBERG Primary education and national development. Stockholm 1973

11. BJÖRN SANDGREN Kreativ utveckling. Stockholm 1974

12. CHRISTER BRUSLING Microteaching - A concept in development. Stockholm 1974

13. KJELL RUBENSON Rekrytering till vuxenutbildning. En studie av kortutbildade yngre män. Göteborg 1975

14. ROGER SÄLJÖ Qualitative differences in learning as a function of the learner's conception of the task. Göteborg 1975

15. LARS OWE DAHLGREN Qualitative differences in learning as a function of content-oriented guidance. Göteborg 1975

16. MARIE MÅNSSON Samarbete och samarbetsförmåga. En kritisk granskning. Lund 1975 17. JAN-ERIC GUSTAFSSON Verbal and figural aptitudes in relation to instructional methods. Studies in aptitude - treatment interactions. Göteborg 1976

18. MATS EKHOLM Social utveckling $i$ skolan. Studier och diskussion. Göteborg 1976
19. LENNART SVENSSON Study skill and learning. Göteborg 1976

20. BJÖRN ANDERSSON Science teaching and the development of thinking. Göteborg 1976

21. JAN-ERIK PERNEMAN Medvetenhet genom utbildning. Göteborg 1977

Editors: Kjell Härnqvist, Ference Marton and Karl-Gustaf Stukát

22. INGA WERNERSSON Könsdifferentiering $i$ grundskolan. Göteborg 1977

23. BERT AGGESTEDT \& ULLA TEBELIUS Barns upplevelser av idrott. Göteborg 1977

24. ANDERS FRANSSON Att rädas prov och att vilja veta. Göteborg 1978

25. ROLAND BJÖRKBERG Föreställningar om arbete, utveckling och livsrytm. Göteborg 1978

26. GUNILLA SVINGBY Läroplaner som styrmedel för svensk obligatorisk skola. Teoretisk analys och ett empiriskt bidrag. Göteborg 1978

27. INGA ANDERSSON Tankestilar och hemmiljö. Göteborg 1979

28. GUNNAR STANGVIK Self-concept and school segregation. Göteborg 1979

29. MARGARETA KRISTIANSSON

Matematikkeunskaper Lgr 62, Lgr 69. Göteborg 1979

30. BRITT JOHANSSON Kunskapsbehov $i$ omvårdnadsarbete och kunskapskrav i vårdutbildning. Göteborg 1979

31. GÖRAN PATRIKSSON Socialisation och involvering $i$ idrott. Göteborg 1979

32. PETER GILL Moral judgments of violence among Irish and Swedish adolescents. Göteborg 1979

33. TAGE LJUNGBLAD Förskola-grundskola $i$ samverkan. Förutsättningar och hinder. Göteborg 1980

34. BERNER LINDSTRÖM Forms of representation, content and learning. Göteborg 1980

35. CLAES-GÖRAN WENESTAM Qualitative

differences in retention. Göteborg 1980

36. BRITT JOHANSSON Pedagogiska samtal $i$ vårdutbildning. Innehåll och språkbruk. Göteborg 1981

37. LEIF LYBECK Arkimedes $i$ klassen. En ämnespedagogisk berättelse. Göteborg 1981

38. BIÖRN HASSELGREN Ways of apprehending children at play. A study of pre-school student teachers' development. Göteborg 1981 
39. LENNART NILSSON Yrkesutbildning $i$ nutidshistoriskt perspektiv. Yrkesutbildningens utveckling frän skràväsendets upphörande 1846 till 1980-talet samt tankar om framtida inriktning. Göteborg 1981

40. GUDRUN BALKE-AURELL Changes in ability as related to educational and occupational experience. Göteborg 1982

41. ROGER SÄLJÖ Learning and understanding. A study of differences in constructing meaning from a text. Göteborg 1982

42. ULLA MARKLUND Droger och paiverkan. Elevanalys som utgangspunkt för drogundervisning. Göteborg 1983

43. SVEN SETTERLIND Avslappningsträning $i$ skolan. Forskningsöversiket och empiriska studier. Göteborg 1983

44. EGIL ANDERSSON \& MARIA LAWENIUS

Lärares uppfattning av undervisning. Göteborg 1983

45. JAN THEMAN Uppfattningar av politisk makt. Göteborg 1983

46. INGRID PRAMLING The child's conception of learning. Göteborg 1983

47. PER OLOF THÅNG Vuxenlärarens förhållningssätt till deltagarerfarenheter. En studie inom AMU. Göteborg 1984

48. INGE JOHANSSON Fritidspedagog på fritidshem. En yrkesgrupps syn på sitt arbete. Göteborg 1984

49. GUNILLA SVANBERG Medansvar i undervisning. Metoder för observation och kvalitativ analys. Göteborg 1984

50. SVEN-ERIC REUTERBERG Studiemedel och rekrytering till bögskolan. Göteborg 1984

51. GÖSTA DAHLGREN \& LARS-ERIK

OLSSON Läsning i barnperspektiv. Göteborg 1985

52. CHRISTINA KÄRRQVIST Kunskapsutveckling genom experimentcentrerade dialoger $i$ ellära. Göteborg 1985

53. CLAES ALEXANDERSSON Stabilitet och förändring. En empirisk studie av förbållandet mellan skolkunskap och vardagsvetande. Göteborg 1985

54. LILLEMOR JERNQVIST Speech regulation of motor acts as used by cerebral palsied children. Observational and experimental studies of a key feature of conductive education. Göteborg 1985

55. SOLVEIG HÄGGLUNDSex-typing and development in an ecological perspective. Göteborg 1986

56. INGRID CARLGREN Lokalt utvecklingsarbete. Göteborg 1986

57. LARSSON, ALEXANDERSSON, HELMSTAD \& THÅNG Arbetsupplevelse och utbildningssyn hos icke facklärda. Göteborg 1986
58. ELVI WALLDAL Studerande vid gymnasieskolans vårdlinje. Förväntad yrkesposition, rollpåverkan, självuppfattning. Göteborg 1986

Editors: Jan-Eric Gustafsson, Ference Marton and Karl-Gustaf Stukát

59. EIE ERICSSON Foreign language teaching from the point of view of certain student activities. Göteborg 1986

60. JAN HOLMER Högre utbildning för lågutbildade $i$ industrin. Göteborg 1987

61. ANDERS HILL \& TULLIE RABE Psykiskt utvecklingsstörda $i$ kommunal förskola. Göteborg 1987

62. DAGMAR NEUMAN The origin of arithmetic skills. A phenomenographic approach. Göteborg 1987

63. TOMAS KROKSMARK Fenomenografisk didaktik. Göteborg 1987

64. ROLF LANDER Utvärderingsforskning - till vilken nytta? Göteborg 1987

65. TORGNY OTTOSSON Map-reading and wayfinding. Göteborg 1987

66. MAC MURRAY Utbildningsexpansion, jämlikhet och avlänkning. Göteborg 1988

67. ALBERTO NAGLE CAJES Studievalet ur den väljandes perspektiv. Göteborg 1988

68. GÖRAN LASSBO Mamma - (Pappa) - barn. En utvecklingsekologisk studie av socialisation i olike a familjetyper. Göteborg 1988

69. LENA RENSTRÖM Conceptions of matter. $A$ phenomenographic approach. Göteborg 1988

70. INGRID PRAMLING Att lära barn lära. Göteborg 1988

71. LARS FREDHOLM Praktik som bärare av undervisnings innehäll och form. En förklaringsmodell for uppkomst av undervisningshandlingar inom en totalförsvarsorganisation. Göteborg 1988

72. OLOF F. LUNDQUIST Studiestöd för vuxna. Utveckling, utnyttjande, utfall. Göteborg 1989

73. BO DAHLIN Religionen, själen och livets mening. En fenomenografisk och existensfilosofisk studie av religionsundervisningens villk.or. Göteborg 1989

74. SUSANNE BJÖRKDAHL ORDELL

Socialarbetare. Bakgrund, utbildning och yrkesliv. Göteborg 1990

75. EVA BJÖRCK-ÅKESSON Measuring Sensation Seeking. Göteborg 1990

76. ULLA-BRITT BLADINI Från hjälpskolelärare till förändringsagent. Svensk speciallärarutbildning 1921-1981 relaterad till specialundervisningens utveckling och förändringar i speciallärarens yrkesuppgifter. Göteborg 1990 
77. ELISABET ÖHRN Könsmönster $i$

klassrumsinteraktion. En observations- och intervjustudie av högstadieelevers lärarkontakter. Göteborg 1991

78. TOMAS KROKSMARK Pedagogikens vägar till dess första svenska professur. Göteborg 1991

Editors: Ingemar Emanuelsson, Jan-Eric Gustafsson and Ference Marton

79. ELVI WALLDAL Problembaserad inlärning. Utvärdering av påbyggnadslinjen Utbildning $i$ öppen hälso- och sjukvård. Göteborg 1991

80. ULLA AXNER Visuella perceptionssvarigheter $i$ skolperspektiv. En longitudinell studie. Göteborg 1991

81. BIRGITTA KULLBERG Learning to learn to read. Göteborg 1991

82. CLAES ANNERSTEDT Idrottslärarna och idrottsämnet. Utveckling, mål, kompetens - ett didaktisk.t perspektiv. Göteborg 1991

83. EWA PILHAMMAR ANDERSSON Det är vi som är dom. Sjuksköterskestuderandes föreställningar och perspektiv under utbildningstiden. Göteborg 1991

84. ELSA NORDIN Kunskaper och uppfattningar om maten och dess funktioner $i$ kroppen. Kombinerad enkät- och intervjustudie i grundskolans årskurser 3, 6 och 9. Göteborg 1992

85. VALENTIN GONZÁLEZ On buman attitudes. Root metaphors in theoretical conceptions. Göteborg 1992

86. JAN-ERIK JOHANSSON Metodikämnet $i$ förskollärarutbildningen. Bidrag till en traditionsbestämning. Göteborg 1992

87. ANN AHLBERG Att möta matematiska problem. En belysning av barns lärande. Göteborg 1992

88. ELLA DANIELSON Omvairdnad och dess psykosociala inslag. Sjuksköterskestuderandes uppfattningar av centrala termer och reaktioner inför en omvardnadssituation. Göteborg 1992

89. SHIRLEY BOOTH Learning to program. A phenomenographic perspective. Göteborg 1992

90. EVA BJÖRCK-ÅKESON Samspel mellan små barn med rörelsehinder och talhandikapp och deras föräldrar - en longitudinell studie. Göteborg 1992

91. KARIN DAHLBERG Helhetssyn i vården. En uppgift för sjuksköterskeutbildningen. 1992

92. RIGMOR ERIKSSON Teaching Language Learning. In-service training for communicative teaching and self directed learning in English as a foreign language. 1993

93. KJELL HÄRENSTAM Skolboks-islam. Analys av bilden av islam i läroböcker $i$ religionskunskap. Göteborg 1993.
94. INGRID PRAMLING Kunnandets grunder. Prönning av en fenomenografisk ansats till att utveckla barns sätt att uppfatta sin omvärld. Göteborg 1994.

95. MARIANNE HANSSON SCHERMAN Att vägra vara sjuk. En longitudinell studie av förhållningssätt till astma/ allergi. Göteborg 1994

96. MIKAEL ALEXANDERSSON Metod och medvetande. Göteborg 1994

97. GUN UNENGE Pappor i föräldrakooperativa daghem. En deskriptiv studie av pappors medverkan. Göteborg 1994

98. BJÖRN SJÖSTRÖM Assessing acute postoperative pain. Assessment strategies and quality in relation to clinical experience and professional role. Göteborg 1995

99. MAJ ARVIDSSON Lärares orsaks- och àtgärdstankar om elever med svarigheter. Göteborg 1995

100. DENNIS BEACH Making sense of the problems of change: An ethnographic study of a teacher education reform. Göteborg 1995.

101. WOLMAR CHRISTENSSON Subjektiv bedömning - som besluts och handlingsunderlag. Göteborg 1995

102. SONJA KIHLSTRÖM Att vara förskollärare. Om yrkets pedagogiska innebörder. Göteborg 1995

103. MARITA LINDAHL Inlärning och erfarande. Ettåringars möte med förskolans värld. Göteborg. 1996

104. GÖRAN FOLKESTAD Computer Based Creative Music Making - Young Peoples' Music in the Digital Age. Göteborg 1996

105. EVA EKEBLAD Children $\bullet$ Learning $\bullet$ Numbers. A phenomenographic excursion into first-grade children's arithmetic. Göteborg 1996

106. HELGE STRÖMDAHL On mole and amount of substance. A study of the dynamics of concept formation and concept attainment. Göteborg 1996

107. MARGARETA HAMMARSTRÖM V arför inte bögskola? En longitudinell studie av olike a faktorers betydelse för studiebegaivade ungdomars utbildningskarriär. Göteborg 1996

108. BJÖRN MÅRDÉN Rektorers tänkande. En kritisk betraktelse av skolledarskap. Göteborg 1996

109. GLORIA DALL'ALBA \& BIÖRN

HASSELGREN (EDS) Reflections on Phenomenography Toward a Methodology? Göteborg 1996

110. ELISABETH HESSLEFORS ARKTOFT I ord och handling. Innebörder av "att anknyta till elevers erfarenheter", uttryckta av lärare. Göteborg 1996

111. BARBRO STRÖMBERG Professionellt förhållningssätt hos läkare och sjuksköterskor. En studie av uppfattningar. Göteborg 1997

112. HARRIET AXELSSON Vagga lära. Om lärare som förändrar sin miljöundervisning. Göteborg 1997 
113. ANN AHLBERG Children's ways of handling and experiencing numbers. Göteborg 1997

114. HUGO WIKSTRÖM Att förstå förändring. Modellbyggande, simulering och gymnasieelevers lärande. Göteborg 1997

115. DORIS AXELSEN Listening to recorded music. Habits and motivation among high-school students. Göteborg 1997.

\section{EWA PILHAMMAR ANDERSSON}

Handledning av sjuksköterskestuderande $i$ klinisk praktik. Göteborg 1997

117. OWE STRÅHLMAN Elitidrott, karriär och avslutning. Göteborg 1997

118. AINA TULLBERG Teaching the 'mole'. A phenomenographic inquiry into the didactics of chemistry. Göteborg 1997.

119. DENNIS BEACH Symbolic Control and Power Relay Learning in Higher Professional Education. Göteborg 1997

120. HANS-ÅKE SCHERP Utmanande eller utmanat ledarskap. Rektor, organisationen och förändrat undervisningsmönster i gymnasieskolan. Göteborg 1998

121. STAFFAN STUKÁT Lärares planering under och efter utbildningen. Göteborg 1998

\section{BIRGIT LENDAHLS ROSENDAHL}

Examensarbetets innebörder. En studie av blivande lärares utsagor. Göteborg 1998

123. ANN AHLBERG Meeting Mathematics. Educational studies with young children. Göteborg 1998

124. MONICA ROSÉN Gender Differences in Patterns of Knowledge. Göteborg 1998.

125. HANS BIRNIK Lärare-elevrelationen. Ett relationistiskt perspektiv. Göteborg 1998

126. MARGRETH HILL Kompetent för "det nya arbetslivet"? Tre gymnasieklasser reflekterar över och diskuterar yrkesförberedande studier. Göteborg 1998

127. LISBETH ÅBERG-BENGTSSON Entering a Graphicate Society. Young Children Learning Graphs and Charts. Göteborg 1998

128. MELVIN FEFFER The Conflict of Equals: $A$ Constructionist View of Personality Development. Göteborg 1999

129. ULLA RUNESSON Variationens pedagogik. Skilda sätt att behandla ett matematisket innehäll. Göteborg 1999

130. SILWA CLAESSON "Hur tänker du da??" Empiriska studier om relationen mellan forskning om elevuppfattningar och lärares undervisning. Göteborg 1999

131. MONICA HANSEN Yrkeskulturer $i$ möte. Läraren, fritidspedagogen och samverkan. Göteborg 1999
132. JAN THELIANDER Att studera arbetets förändring under kapitalismen. Ure och Taylor i pedagogisk.t perspektiv. Göteborg 1999

133. TOMAS SAAR Musikens dimensioner - en studie av unga musikers lärande. Göteborg 1999

134. GLEN HELMSTAD Understandings of understanding. An inquiry concerning experiential conditions for developmental learning. Göteborg 1999

\section{MARGARETA HOLMEGAARD}

Språkmedvetenhet och ordinlärning. Lärare och inlärare reflekterar kring en betydelsefältsöuning $i$ svenska som andraspräk. Göteborg 1999

136. ALYSON MCGEE Investigating Language Anxiety through Action Inquiry: Developing Good Research Practices. Göteborg 1999

137. EVA GANNERUD Genusperspektiv på lärargärning. Om kvinnliga klasslärares liv och arbete. Göteborg 1999

138. TELLERVO KOPARE Att rida stormen ut. Förlossningsberättelser i Finnmark och Sápmi. Göteborg 1999

139. MAJA SÖDERBÄCK Encountering Parents. Professional Action Styles among Nurses in Pediatric Care. Göteborg 1999

140. AIRI ROVIO - JOHANSSON Being Good at Teaching. Exploring different ways of handling the same subject in Higher Education. Göteborg 1999

141. EVA JOHANSSON Etik $i$ små barns värld. Om värden och normer bland de yngsta barnen i förskolan. Göteborg 1999

142. KENNERT ORLENIUS Förståelsens paradox. Yrkeserfarenhetens betydelse när förskollärare blir grundskollärare. Göteborg 1999.

143. BJÖRN MÅRDÉN De nya hälsomissionärernarörelser $i$ korsvägen mellan pedagogik och hälsopromotion. Göteborg 1999

144. MARGARETA CARLÉN Kunskapslyft eller avbytarbänk? Möten med industriarbetare om utbildning för arbete. Göteborg 1999

145. MARIA NYSTRÖM Allvarligt psykisket störda människors vardagliga tillvaro. Göteborg 1999

146. ANN-KATRIN JAKOBSSON Motivation och inlärning ur genusperspektiv. En studie av gymnasieelever på teoretiska linjer/program. Göteborg 2000

147. JOANNA GIOTA Adolescents'perceptions of school and reasons for learning. Göteborg 2000

148. BERIT CARLSTEDT Cognitive abilities - aspects of structure, process and measurement. Göteborg 2000

149. MONICA REICHENBERG Röst och kausalitet $i$ lärobokstexter. En studie av elevers förståelse av olika textversioner. Göteborg 2000 
150. HELENA ÅBERG Sustainable waste management in bouseholds - from international policy to everyday practice. Experiences from two Swedish field studies. Göteborg 2000

151. BJÖRN SJÖSTRÖM \& BRITT JOHANSSON Ambulanssjukvard. Ambulanssjukvardares och läkares perspektiv. Göteborg 2000

152. AGNETA NILSSON Omvardnadskompetens inom hemsjukvård - en deskriptiv studie. Göteborg 2001

153. ULLA LÖFSTEDT Förskolan som lärandekontext för barns bildskapande. Göteborg 2001

154. JÖRGEN DIMENÄS Innebaill och interaktion. Om elevers lärande i naturvetenskaplig undervisning. Göteborg 2001

155. BRITT MARIE APELGREN Foreign Language Teachers' Voices. Personal Theories and Experiences of Change in Teaching English as a Foreign Language in Sweden. Göteborg 2001

156. CHRISTINA CLIFFORDSON Assessing empathy: Measurement characteristics and interviewer effects. Göteborg 2001

157. INGER BERGGREN Identitet, kön och klass. Hur arbetarflickor formar sin identitet. Göteborg 2001

158. CARINA FURÅKER Styming och visionersjukskoöterskeutbildning i förändring. Göteborg 2001

159. INGER BERNDTSSON Förskjutna horisonter. Livsförändring och lärande $i$ samband med synnedsättning eller blindhet. Göteborg 2001

160. SONJA SHERIDAN Pedagogical Quality in Preschool. An issue of perspectives. Göteborg 2001

161. JAN BAHLENBERG Den otroliga verkligheten sätter spair. Om Carlo Derkerts liv och konstpedagogiska gärning. Göteborg 2001

162. FRANK BACH Om liuset i tillvaron. Ett undervisningsexperiment inom optik. Göteborg 2001

163. PIA WILLIAMS Barn lär av varandra. Samlärande i forrskola och skola. Göteborg 2001

164. VIGDIS GRANUM Studentenes forestillinger om sykepleie som fag og funksjon. Göteborg 2001

165. MARIT ALVESTAD Den komplekese planlegginga. Forskolelararar om pedagogisk. planlegging og praksis. Göteborg 2001

166. GIRMA BERHANU Learning-In-Context. An Ethnographic Investigation of Mediated Learning Experiences among Ethiopian Jews in Israel. Göteborg 2001.

167. OLLE ESKILSSON En longitudinell studie av 10 - 12-åringars forrståelse av materiens förändringar. Göteborg 2001

168. JONAS EMANUELSSON En fråga om frågor. Hur lärares fragor $i$ klassrummet gör det möjligt att fä reda på elevernas sätt att forrstå det som undervisningen behandlar $i$ matematik och naturvetenskap. Göteborg 2001
169. BIRGITTA GEDDA Den offentliga hemligheten. En studie om sjuksköterskans pedagogiska funktion och kompetens i folkhälsoarbetet. Göteborg 2001

170. FEBE FRIBERG Pedagogiska möten mellan patienter och sjuksköterskor på en medicinsk vårdavdelning. Mot en vårddidaktik på livsvärldsgrund. Göteborg 2001

171. MADELEINE BERGH Medvetenhet om bemötande. En studie om sjuksköterskans pedagogiska funktion och kompetens i närståendeundervisning. Göteborg 2002

172. HENRIK ERIKSSON Den diplomatiska punketen - maskulinitet som kroppsligt identitetsskapande projekt $i$ svensk. sjuksköterskeutbildning. Göteborg 2002

173. SOLVEIG LUNDGREN I spåren av en bemanningsförändring. En studie av sjuksköterskors arbete på en kirurgisk vårdavdelning. Göteborg 2002

174. BIRGITTA DAVIDSSON Mellan soffan och katedern. En studie av hur förskollärare och grundskollärare utvecklar pedagogisk integration mellan förskola och skola. Göteborg 2002

175. KARI SØNDENÅ Tradisjon og Transcendens - ein fenomenologisk studie av refleksson i norsk. forskulelararutdanning. Göteborg 2002

176. CHRISTINE BENTLEY The Roots of Variation of English-Teaching. A Phenomenographic Study Founded on an Alternative Basic Assumption. Göteborg 2002

177. ÅSA MÄKITALO Categorizing Work: Knowing, Arguing, and Social Dilemmas in Vocational Guidance. Göteborg 2002

178. MARITA LINDAHL $V A R D A-V \ddot{A G L E D A}$ - LÄRA. Effeketstudie av ett interventionsprogram för pedagogers lärande i förskolemiljön. Göteborg 2002

179. CHRISTINA BERG Influences on schoolchildren's dietary selection. Focus on fat and fibre at breakfast. Göteborg 2002

180. MARGARETA ASP Vila och lärande om vila. En studie på livsvärldsfenomenologisk grund. Göteborg 2002

181. FERENCE MARTON \& PAUL MORRIS (EDS) What matters? Discovering critical contitions of classroom learning. Göteborg 2002

182. ROLAND SEVERIN Dom vet vad dom talar om. En intervjustudie om elevers uppfattningar av begreppen makt och sambällsförändring. Göteborg 2002

Editors: Björn Andersson, Jan Holmer and Ingrid Pramling Samuelsson

183. MARLÉNE JOHANSSON Slöjpraktik $i$ skolan - hand, tanke, kommunikation och andra medierande redskap. Göteborg 2002 
184. INGRID SANDEROTH Om lust att lära $i$ skolan: En analys av dokument och klass 8y. Göteborg 2002

185. INGA-LILL JAKOBSSON Diagnos $i$ skolan. En studie av skolsituationer för elever med syndromdiagnos. Göteborg 2002

186. EVA-CARIN LINDGREN Empowering Young Female Athletes - A Possible Challenge to the Male Hegemony in Sport. A Descriptive and Interventional Study. Göteborg 2002

187. HANS RYSTEDT Bridging practices. Simulations in education for the health-care professions. Göteborg 2002

188. MARGARETA EKBORG Naturvetenskaplig utbildning för hallbar utveckling? En longitudinell studie av bur studenter på grunskollärarprogrammet utvecklar för miljöundervisning relevanta kunskaper i naturkunskap. Göteborg 2002

189. ANETTE SANDBERG Vuxnas lekvärld. En studie om vuxnas erfarenheter av lek. Göteborg 2002

190. GUNLÖG BREDÄNGE Gränslös pedagog. Fyra studier om utländska lärare i svensk skola. Göteborg 2003

191. PER-OLOF BENTLEY Mathematics Teachers and Their Teaching. A Survey Study. Göteborg 2003

192. KERSTIN NILSSON MANDAT - MAKT $M A N A G E M E N T$. En studie av hur vardenhetschefers ledarskap konstrueras. Göteborg 2003

193. YANG YANG Measuring Socioeconomic Status and its Effects at Individual and Collective Levels: A CrossCountry Comparison. Göteborg 2003

194. KNUT VOLDEN Mediekunnskap som mediekritik.k. Göteborg 2003.

195. LOT'TA LAGER-NYQVIST Att göra det man kan - en longitudinell studie av hur sju lärarstudenter utvecklar sin undervisning och formar sin lärarroll $i$ naturvetenskap. Göteborg 2003

196. BRITT LINDAHL Lust att lära naturvetenskap och teknik? En longitudinell studie om vägen till gymnasiet. Göteborg 2003

197. ANN ZETTERQVIST Ämnesdidaktisk kompetens i evolutionsbiologi. En intervjuundersökning med no/biologilärare. Göteborg 2003

198. ELSIE ANDERBERG Språkanvändningens funktion vid utveckling av kunskap om objekt. Göteborg 2003.

199. JAN GUSTAFSSON Integration som text, diskursiv och social praktik. En policyetnografisk fallstudie av mötet mellan skolan och förskoleklassen. Göteborg 2003.

200. EVELYN HERMANSSON Akademisering och professionalisering - barnmorskans utbildning i förändring. Göteborg 2003

201. KERSTIN VON BRÖMSSEN Tolkningar, förhandlingar och tystnader. Elevers tal om religion $i$ det mångkulturella och postkoloniala rummet. Göteborg 2003
202. MARIANNE LINDBLAD FRIDH Fran allmänsjuksköterska till specialistsjuksköterska inom intensivvaird. En studie av erfarenheter frän specialistutbildningen och frän den första yrkesverksamma tiden inom intensivvarden. Göteborg 2003

203. BARBRO CARLI The Making and Breaking of a Female Culture: The History of Swedish Physical Education 'in a Different Voice'. Göteborg 2003

204. ELISABETH DAHLBORG-LYCKHAGE

"Systers" konstruktion och mumifiering - $i$ TV-serier och $i$ studenters föreställningar. Göteborg 2003

205. ULLA HELLSTRÖM MUHLI Att överbrygga perspektiv. En studie av behousbedömningssamtal inom äldreinriktat socialt arbete. Göteborg 2003

206. KRISTINA AHLBERG Synvändor.

Universitetsstudenters berättelser om kvalitativa förändringar av sätt att erfara situationers mening under utbildningspraktik. Göteborg 2004

207. JONAS IVARSSON Renderings \& Reasoning: Studying artifacts in buman knowing. Göteborg 2004

208. MADELEINE LÖWING

Matematikundervisningens konkreta gestaltning. En studie av kommunikationen lärare - elev och matematiklektionens didaktiska ramar. Göteborg 2004

209. PIJA EKSTRÖM Makten att definiera. En studie av hur beslutsfattare formulerar villkor för specialpedagogisk verksamhet. Göteborg 2004

210. CARIN ROOS Skriftspräkande döva barn. En studie om skriftspräkligt lärande i förskola och skola. Göteborg 2004

211. JONAS LINDEROTH Datorspelandets mening. Bortom idén om den interaktiva illusionen. Göteborg 2004

212. ANITA WALLIN Evolutionsteorin $i$ klassrummet. $P a ̊$ väg mot en ämnesdidaktisk teori för undervisning $i$ biologisk evolution. Göteborg 2004

213. EVA HJÖRNE Excluding for inclusion? Negotiating school careers and identities in pupil welfare settings in the Swedish school. Göteborg 2004

214. MARIE BLIDING Inneslutandets och uteslutandets praktik. En studie av barns relationsarbete i skolan. Göteborg 2004

215. LARS-ERIK.JONSSON Appropriating Technologies in Educational Practices. Studies in the Contexts of Compulsory Education, Higher Education, and Fighter Pilot Training. Göteborg 2004

216. MIA KARLSSON An ITiS Teacher Team as a Community of Practice. Göteborg 2004

217. SILWA CLAESSON Lärares levda kunskap. Göteborg 2004

218. GUN-BRITT WÄRVIK Ambitioner att förändra och artefakters verkan. Gränsskapande och stabiliserande praktiker på produktionsgolvet. Göteborg 2004 
219. KARIN LUMSDEN WASS Vuxenutbildning $i$ omvandling. Kunskapslyftet som ett sätt att organisera förnyelse. Göteborg 2004

220. LENA DAHL Amningspraktikens villkor. En intervjustudie av en grupp kvinnors föreställningar på och erfarenheter av amning. Göteborg 2004

221. ULRIC BJÖRCK Distributed Problem-Based Learning. Studies of a Pedagogical Model in Practice. Göteborg 2004

222. ANNEKA KNUTSSON" "To the best of your knowledge and for the good of your neighbour". A study of traditional birth attendants in Addis Ababa, Ethiopia. Göteborg 2004

223. MARIANNE DOVEMARK Ansvar-flexibilitet - valfribet. En etnografisk studie om en skola i förändring. Göteborg 2004

224. BJÖRN HAGLUND Traditioner $i$ möte. En kvalitativ studie av fritidspedagogers arbete med samlingar $i$ skolan. Göteborg 2004

225. ANN-CHARLOTTE MÅRDSJÖ Lärandets skiftande innebörder - uttryckta av förskollärare $i$ vidareutbildning. Göteborg 2005

226. INGRID GRUNDÉN Att àtererövra kroppen. En studie av livet efter en ryggmärgsskada. Göteborg 2005

227. KARIN GUSTAFSSON \& ELISABETH

MELLGREN Barns skriftspräkande - att bli en skrivande och läsande person. Göteborg 2005

228. GUNNAR NILSSON Att äga $\pi$. Praxisnära studier av lärarstudenters arbete med geometrilaborationer. Göteborg 2005.

229. BENGT LINDGREN Bild, visualitet och vetande. Diskussion om bild som ett kunskapsfält inom utbildning. Göteborg 2005

230. PETRA ANGERVALL Jämställdhetsarbetets pedagogik. Dilemman och paradoxer $i$ arbetet med jämställdhet på ett företag och ett universitet. Göteborg 2005

231. LENNART MAGNUSSON Designing a responsive support service for family carers of frail older people using ICT. Göteborg 2005

232. MONICA REICHENBERG Gymnasieelever samtalar kring facktexter. En studie av textsamtal med goda och svaga läsare. Göteborg 2005

233. ULRIKA WOLFF Characteristics and varieties of poor readers. Göteborg 2005

234. CECILIA NIELSEN Mellan fakticitet och projekt. Läs-och skrivsvårigheter och strävan att övervinna dem. Göteborg 2005.

235. BERITH HEDBERG Decision Making and Communication in Nursing Practice. Aspects of Nursing Competence. Göteborg 2005
236. MONICA ROSÉN, EVA MYRBERG \& JANERIC GUSTAFSSON Läskompetens $i$ skolar 3 och 4. Nationell rapport fran PIRLS 2001 i Sverige. The IEA Progress in International Reading Literacy Study. Göteborg 2005

237. INGRID HENNING LOEB Utveckling och förändring $i$ kommunal vuxenutbildning. En yrkeshistorisk ingång med berättelser om lärarbanor. Göteborg 2006.

238. NIKLAS PRAMLING Minding metaphors: Using figurative language in learning to represent. Göteborg 2006

239. KONSTANTIN KOUGIOUMTZIS

Lärarkulturer och professionskoder. En komparativ studie av idrottslärare i Sverige och Grekland. Göteborg 2006

240. STEN BÅTH Kvalifikation och medborgarfostran. En analys av reformtexter avseende gymnasieskolans sambällsuppdrag. Göteborg 2006.

241. EVA MYRBERG Fristäende skolor i Sverige Effeketer på 9-10-åriga elevers läsförmåga. Göteborg 2006

242. MARY-ANNE HOLFVE-SABEL Attitudes towards Swedish comprehensive school. Comparisons over time and between classrooms in grade 6. Göteborg 2006

243. CAROLINE BERGGREN Entering Higher

Education - Gender and Class Perspectives. Göteborg 2006

244. CRISTINA THORNELL \& CARL

OLIVESTAM Kulturmöte i centralafrikansk kontext med kyrkan som arena. Göteborg 2006

245. ARVID TREEKREM Att leda som man lär. En arbetsmiljöpedagogisk studie av toppledares ideologier om ledarskapets taktiska potentialer. Göteborg 2006

246. EVA GANNERUD \& KARIN

RÖNNERMAN Inneball och innebörd i lärares arbete $i$ förskola och skola - en fallstudie ur ett genusperspektiv. Göteborg 2006

247. JOHANNES LUNNEBLAD Förskolan och mångfalden - en etnografisk studie på en förskola $i$ ett multietniskt område. Göteborg 2006

248. LISA ASP-ONSJÖ Atgärdsprogram - dokument eller verktyg? En fallstudie i en kommun. Göteborg 2006

249. EVA JOHANSSON \& INGRID PRAMLING SAMUELSSON Lek och läroplan. Möten mellan barn och lärare i förskola och skola. Göteborg 2006

250. INGER BJÖRNELOO Innebörder av hållbar utveckling. En studie av lärares utsagor om undervisning. Göteborg 2006

251. EVA JOHANSSON Etiska överenskommelser i förskolebarns världar. Göteborg 2006

252. MONICA PETERSSON Att genuszappa på säker eller osäker mark. Hem- och konsumentkunskap ur ett könsperspektiv. Göteborg 2007

253. INGELA OLSSON Handlingskompetens eller inlärd hjälplöshet? Lärandeprocesser hos verkstadsindustriarbetare. Göteborg 2007 
254. HELENA PEDERSEN The School and the Animal Other. An Ethnography of human-animal relations in education. Göteborg 2007

255. ELIN ERIKSEN ØDEGAARD Meningsskaping $i$ barnehagen. Innhold og bruk av barns og voksnes samtalefortellinger. Göteborg 2007

256. ANNA KLERFELT Barns multimediala berättande. En länk mellan mediakultur och pedagogisk. praktik. Göteborg 2007

257. PETER ERLANDSON Docile bodies and imaginary minds: on Schön's reflection-in-action. Göteborg 2007

258. SONJA SHERIDAN OCH PIA WILLIAMS

Dimensioner av konstruktiv konkurrens. Konstruktiva

konkurrensformer i förskola, skola och gymnasium.

Göteborg 2007

259. INGELA ANDREASSON Elerplanen som text om identitet, genus, makt och styrning $i$ skolans elevdokumentation. Göteborg 2007

Editors: Jan-Eric Gustafsson, Annika Härenstam and Ingrid Pramling Samuelsson

260. ANN-SOFIE HOLM Relationer $i$ skolan. En studie av femininiteter och maskuliniteter $i$ à 9. Göteborg 2008

261. LARS-ERIK NILSSON But can't you see they are lying: Student moral positions and ethical practices in the wake of technological change. Göteborg 2008

262. JOHAN HÄGGSTRÖM Teaching systems of linear equations in Sweden and China: What is made possible to learn? Göteborg 2008

263. GUNILLA GRANATH Milda makter! Utvecklingssamtal och loggböcker som disciplineringstekniker. Göteborg 2008

264. KARIN GRAHN Flickor och pojkar i idrottens

läromedel. Konstruktioner av genus $i$ ungdomstränarutbildningen. Göteborg 2008.

265. PER-OLOF BENTLEY Mathematics Teachers and Their Conceptual Models. A New Field of Research. Göteborg 2008

266. SUSANNE GUSTAVSSON Motstand och mening. Innebörd i blivande lärares seminariesamtal. Göteborg 2008

267. ANITA MATTSSON Flexibel utbildning $i$ praktiken. En fallstudie av pedagogiska processer $i$ en distansutbildning med en öppen design för samarbetslärande. Göteborg 2008

268. ANETTE EMILSON Det önskvärda barnet. Fostran uttryckt $i$ vardagliga kommunikationshandlingar mellan lärare och barn i förskolan. Göteborg 2008
269. ALLI KLAPP LEKHOLM Grades and grade assignment: effects of student and school charachterisitcs. Göteborg 2008

270. ELISABETH BJÖRKLUND Att erörra litteracitet. Smà barns kommunikativa möten med berättande, bilder, text och tecken i förskolan. Göteborg 2008

271. EVA NYBERG Om livets kontinuitet. Undervisning och lärande om växters och djurs livscykler - en fallstudie $i$ årskurs 5. Göteborg 2008

\section{CANCELLED}

273. ANITA NORLUND Kritisk sakprosaläsning $i$ gymnasieskolan. Didaktiska perspektiv på läroböcker, lärare och nationella prov. Göteborg 2009

\section{AGNETA SIMEONSDOTTER SVENSSON}

Den pedagogiska samlingen i förskoleklasen. Barns olika sätt att erfara och hantera svairigheter. Göteborg 2009

275. ANITA ERIKSSON Om teori och praktik $i$ lärarutbildningen. En etnografisk och diskursanalytisk studie. Göteborg 2009

276. MARIA HJALMARSSON Lärarprofessionens genusordning. En studie av lärares uppfattningar om arbetsuppgifter, kompetens och förväntningar. Göteborg 2009.

277. ANNE DRAGEMARK OSCARSON SelfAssessement of Writing in Learning English as a Foreign Language. A Study at the Upper Secondary School Level. Göteborg 2009

278. ANNIKA LANTZ-ANDERSSON Framing in Educational Practices. Learning Activity, Digital Technology and the Logic of Situated Action. Göteborg 2009

279. RAUNI KARLSSON Demokratiska värden i förskolebarns vardag. Göteborg 2009

280. ELISABETH FRANK Läsförmågan bland 9-10aringar. Betydelsen av skolklimat, hem-och skolsamverkan, lärarkompetens och elevers hembakgrund. Göteborg 2009

281. MONICA JOHANSSON Anpassning och motstaind. En etnografisk studie av gymnasieelevers institutionella identitetsskeapande. Göteborg 2009

282. MONA NILSEN Food for Thought. Communication and the transformation of work experience in web-based inservice training. Göteborg 2009

283. INGA WERNERSSON (RED) Genus i förskola och skola. Förändringar i policy, perspektiv och praktik. Göteborg 2009

284. SONJA SHERIDAN, INGRID PRAMLING SAMUELSSON \& EVA JOHANSSON (RED) Barns tidiga lärande. En tvärsnittsstudie om förskolan som miljö för barns lärande. Göteborg 2009

285. MARIE HJALMARSSON Lojalitet och motstand anställdas agerande $i$ ett föränderligt hemtjänstarbete. Göteborg 2009. 
286. ANETTE OLIN Skolans mötespraktik - en studie om skolutveckling genom yrkesverksammas förståelse. Göteborg 2009

287. MIRELLA FORSBERG AHLCRONA

Handdockans kommunikativa potential som medierande redskap i förskolan. Göteborg 2009

288. CLAS OLANDER Towards an interlanguage of biological evolution: Exploring students' talk and writing as an arena for sense-making. Göteborg 2010

Editors: Jan-Eric Gustafsson, Åke Ingerman and Ingrid Pramling Samuelsson

289. PETER HASSELSKOG Slöjdlärares förhållningssätt $i$ undervisningen. Göteborg 2010

290. HILLEVI PRELL Promoting dietary change. Intervening in school and recognizing health messages in commercials. Göteborg 2010

291. DAVOUD MASOUMI Quality Within E-learning in a Cultural Context. The case of Iran. Göteborg 2010

292. YLVA ODENBRING Kramar, kategoriseringar och bjälpfröknar. Könskonstruktioner i interaktion i förskola, förskoleklass och skolair ett. Göteborg 2010

293. ANGELIKA KULLBERG What is tanght and what is learned. Professional insights gained and shared by teachers of mathematics. Göteborg 2010

294. TORGEIR ALVESTAD Barnehagens relasjonelle verden - små barn som kompetente aktorer i produktive forhandlinger: Göteborg 2010

295. SYLVI VIGMO New spaces for Language Learning. A study of student interaction in media production in English. Göteborg 2010

296. CAROLINE RUNESDOTTER I otakt med tiden? Folkbögskolorna i ett föränderligt fält. Göteborg 2010

297. BIRGITTA KULLBERG En etnografisk studie $i$ en thailändsk grundskola på en ö i södra Thailand. I sökandet efter en framtid då nuet har nog av sitt. Göteborg 2010

298. GUSTAV LYMER The work of critique in architectural education. Göteborg 2010

299. ANETTE HELLMAN Kan Batman vara rosa? Förhandlingar om pojkighet och normalitet på en forrkola. Göteborg 2010

300. ANNIKA BERGVIKEN-RENSFELDT Opening higher education. Discursive transformations of distance and higher education government. Göteborg 2010

301. GETAHUN YACOB ABRAHAM Education for Democracy? Life Orientation: Lessons on Leadership Qualities and Voting in South African Comprehensive Schools. Göteborg 2010

302. LENA SJÖBERG Bäst $i$ klassen? Lärare och elever $i$ svenske och europeiska policytexter. Göteborg 2011
303. ANNA POST Nordic stakeholders and sustainable catering. Göteborg 2011

304. CECILIA KILHAMN Making Sense of Negative

Numbers. Göteborg 2011

305. ALLAN SVENSSON (RED) Utvärdering Genom Uppföljning. Longitudinell individforskning under ett halvsekel. Göteborg 2011

306. NADJA CARLSSON I kamp med skriftspråket.

$V$ uxenstuderande med läs- och skrivsvarigheter $i$ ett livsvärldsperspektiv. Göteborg 2011

307. AUD TORILL MELAND Ansvar for egen laring. Intensjoner og realiteter ved en norsk videregående skole. Göteborg 2011

308. EVA NYBERG Folkbildning för demokrati. Colombianska kvinnors perspektiv på kunskap som förändringskeraft. Göteborg 2011

309. SUSANNE THULIN Lärares tal och barns nyfikenhet. Kommunikation om naturvetenskapliga inneball $i$ förskolan. Göteborg 2011

310. LENA FRIDLUND Interkulturell undervisning ett pedagogiskt dilemma. Talet om undervisning i svenska som andraspråk och i förberedelseklass. Göteborg 2011

311. TARJA ALATALO Skicklig läs- och skrivundervisning $i$ åk 1-3. Om lärares möjligheter och hinder. Göteborg 2011

312. LISE-LOTTE BJERVÅS Samtal om barn och pedagogisk dokumentation som bedömningspraktik $i$ förskolan. En diskursanalys. Göteborg 2011

313. ÅSE HANSSON Ansvar för matematiklärande. Effekter av undervisningsansvar $i$ det flerspråkiga klassrummet. Göteborg 2011

314. MARIA REIS Att ordna, fran ordning till ordning. Yngre förskolebarns matematiserande. Göteborg 2011

315. BENIAMIN KNUTSSON Curriculum in the Era of Global Development - Historical Legacies and Contemporary Approaches. Göteborg 2011

316. EVA WEST Undervisning och lärande $i$ naturvetenskap. Elevers lärande i relation till en forskningsbaserad undervisning om ljud, hörsel och hälsa. Göteborg 2011

317. SIGNILD RISENFORS Gymnasieungdomars livstolkande. Göteborg 2011

318. EVA JOHANSSON \& DONNA

BERTHELSEN (Ed.) Spaces for Solidarity and Individualism in Educational Contexts. Göteborg 2012

319. ALASTAIR HENRY L3 Motivation. Göteborg 2012

320. ANN PARINDER Ungdomars matvalerfarenheter, visioner och miljöargument $i$ eget bushåll. Göteborg 2012

321. ANNE KULTTI Flerspråkiga barn i förskolan: Villkor för deltagande och lärande. Göteborg 2012 
322. BO-LENNART EKSTRÖM Kontroversen om $D A M P$. En kontroversstudie av vetenskapligt gränsarbete och översättning mellan olika kunskapsparadigm. Göteborg 2012

323. MUN LING LO V ariation Theory and the Improvement of Teaching and Learning. Göteborg 2012

324. ULLA ANDRÉN Self-awareness and self-knowledge in professions. Something we are or a skill we learn. Göteborg 2012

325. KERSTIN SIGNERT Variation och invarians $i$ Maria Montessoris sinnestränande materiel. Göteborg 2012

326. INGEMAR GERRBO Idén om en skola för alla och specialpedagogisk organisering i praktiken. Göteborg 2012

327. PATRIK LILJA Contextualizing inquiry.

Negotiations of tasks, tools and actions in an upper secondary classroom. Göteborg 2012

328. STEFAN JOHANSSON On the Validity of Reading Assessments: Relationships Between Teacher Judgements, External Tests and Pupil Self-assessments. Göteborg 2013

329. STEFAN PETTERSSON Nutrition in Olympic Combat Sports. Elite athletes' dietary intake, bydration status and experiences of weight regulation. Göteborg 2013

330. LINDA BRADLEY Language learning and technology - student activities in web-based environments. Göteborg 2013

331. KALLE JONASSON Sport Has Never Been Modern. Göteborg 2013

332. MONICA HARALDSSON STRÄNG Yngre elevers lärande om natur. En studie av kommunikation om modeller i institutionella kontexter. Göteborg 2013

333. ANN VALENTIN KVIST Immigrant Groups and Cognitive Tests - V alidity Issues in Relation to Vocational Training. Göteborg 2013

334. ULRIKA BENNERSTEDT Knowledge at play. Studies of games as members' matters. Göteborg 2013

335. EVA ÄRLEMALM-HAGSÉR Engagerade $i$ världens bästa? Lärande för hållbarhet i förskolan. Göteborg 2013

336. ANNA-KARIN WYNDHAMN Tänka fritt, tänka rätt. En studie om värdeöverföring och kritiskt tänkande i gymnasieskolans undervisning. Göteborg 2013

337. LENA TYRÈN "Vi fär ju inte riktigt förutsättningarna för att genomföra det som vi vill." En studie om lärares möjligheter och hinder till förändring och förbättring ipraktiken. Göteborg 2013

Editors: Jan-Eric Gustafsson, Åke Ingerman and Pia Williams
338. ANNIKA LILJA Förtroendefulla relationer mellan lärare och elev. Göteborg 2013

339. MAGNUS LEVINSSON Evidens och existens.

Evidensbaserad undervisning $i$ ljuset av lärares erfarenheter. Göteborg 2013

340. ANNELI SCHWARTZ Pedagogik, plats och prestationer. En etnografisk studie om en skola i förorten. Göteborg 2013

341. ELISABET ÖHRN och LISBETH LUNDAHL (red) Kön och karriär $i$ akademin. En studie inom det utbildningsvetenskapliga fältet. Göteborg 2013

342. RICHARD BALDWIN Changing practice by reform. The recontextualisation of the Bologna process in teacher education. Göteborg 2013

343. AGNETA JONSSON Att skapa läroplan för de yngsta barnen i förskolan. Barns perspektiv och nuets didaktik. Göteborg 2013

344. MARIA MAGNUSSON Skylta med kunskap. En studie av hur barn urskiljer grafiska symboler $i$ hem och förskola. Göteborg 2013

345. ANNA-LENA LILLIESTAM Aktör och struktur $i$ historieundervisning. Om utveckling av elevers historiska resonerande. Göteborg 2013

346. KRISTOFFER LARSSON Kritiskt tänkande i grundskolans sambällskunskap. En fenomenografisk studie om manifesterat kritiskt tänkande $i$ sambällskunskap hos elever $i$ årskurs 9. Göteborg 2013

347. INGA WERNERSSON och INGEMAR GERRBO (red) Differentieringens janusansikte. En antologi frän Institutionen för pedagogik och specialpedagogik vid Göteborgs universitet. Göteborg 2013

348. LILL LANGELOTZ Vad gör en skicklig lärare? En studie om kollegial handledning som utvecklingspraktik. Göteborg 2014

349. STEINGERDUR OLAFSDOTTIR Television and food in the lives of young children. Göteborg 2014

350. ANNA-CARIN RAMSTEN Kunskaper som byggde folkhemmet. En fallstudie av förutsättningar för lärande vid teknikskiften inom processindustrin. Göteborg 2014

351. ANNA-CARIN BREDMAR Lärares arbetsglädje. Betydelsen av emotionell närvaro $i$ det pedagogiska arbetet. Göteborg 2014

352. ZAHRA BAYATI "den Andre" i lärarutbildningen. En studie om den rasifierade svenska studentens villkor $i$ globaliseringens tid. Göteborg 2014

353 ANDERS EKLÖF Project work, independence and critical thinking. Göteborg 2014

354 EVA WENNÅS BRANTE Möte med multimodalt material. Vilken roll spelar dyslexi för uppfattandet av text och bild? Göteborg 2014

355 MAGNUS FERRY Idrottsprofilerad utbildning - i spåren av en avreglerad skola. Göteborg 2014 
356 CECILIA THORSEN Dimensionality and Predictive validity of school grades: The relative influence of cognitive and socialbehavioral aspects. Göteborg 2014

357 ANN-MARIE ERIKSSON Formulating knowledge. Engaging with issues of sustainable development through academic writing in engineering education. Göteborg 2014

358 PÄR RYLANDER Tränares makt över spelare $i$ lagidrotter: Sett ur French och Ravens maktbasteori. Göteborg 2014

359 PERNILLA ANDERSSON VARGA

Skrivundervisning i gymnasieskolan. Svenskämnets roll $i$ den sociala reproduktionen. Göteborg 2014

360 GUNNAR HYLTEGREN Vaghet och vanmakt - 20 ar med kunskapskrav i den svenska skolan.

Göteborg 2014

361 MARIE HEDBERG Idrotten sätter agendan. En studie av Riksidrottsgymnasietränares handlande utifrän sitt dubbla uppdrag. Göteborg 2014

362 KARI-ANNE JøRGENSEN What is going on out there? - What does it mean for children's experiences when the kindergarten is moving their everyday activities into the nature landscapes and its places? Göteborg 2014

363 ELISABET ÖHRN och ANN-SOFIE HOLM (red) Att lyckas i skolan. Om skolprestationer och kön $i$ olika undervisningspraktiker. Göteborg 2014

364 ILONA RINNE Pedagogisk takt $i$ betygssamtal. En fenomenologisk hermeneutisk studie av gymnasielärares och elevers förståelse av betyg. Göteborg 2014

365 MIRANDA ROCKSÉN Reasoning in a Science Classroom. Göteborg 2015

366 ANN-CHARLOT'TE BIVALL Helpdesking:

Knowing and learning in IT support practices.

Göteborg 2015

367 BIRGITTA BERNE Naturvetenskap möter etik. En klassrumsstudie av elevers diskussioner om sambällsfrägor relaterade till bioteknik. Göteborg 2015

368 AIRI BIGSTEN Fostran i förskolan.

Göteborg 2015

369 MARITA CRONQVIST Yrkesetik i lärarutbildning - en balanskonst. Göteborg 2015

370 MARITA LUNDSTRÖM Förskolebarns strävanden att kommunicera matematik. Göteborg 2015

371 KRISTINA LANÅ Makt, kön och diskurser.

En etnografisk studie om elevers aktörsskeap och positioneringar i undervisningen. Göteborg 2015

372 MONICA NYVALLER Pedagogisk utveckling genom kollegial granskning: Fallet Lärande Besök utifrän aktör-nätverksteori. Göteborg 2015
373 GLENN ØVREVIK KJERLAND

A lare à undervise $i$ kroppsoving. Design for utvikling av teoribasert undervisning og kritisk refleksjon $i$ kroppsøvingslarerutdanningen. Göteborg 2015

374 CATARINA ECONOMOU "I svenskea två vågar jag prata mer och så’. En didaktisk studie om skolämnet svenska som andraspråk. Göteborg 2015

375 ANDREAS OTTEMO Kön, kropp, begär och teknik: Passion och instrumentalitet på två tekniska bögskoleprogram. Göteborg 2015

376 SHRUTI TANEJA JOHANSSON Autism-incontext. An investigation of schooling of children with a diagnosis of autism in urban India. Göteborg 2015

377 JAANA NEHEZ Rektorers praktiker i möte med utvecklingsarbete. Möjligheter och hinder för planerad förändring. Göteborg 2015

378 OSA LUNDBERG Mind the Gap - Ethnography about cultural reproduction of difference and disadvantage in urban education. Göteborg 2015

379 KARIN LAGER I spänningsfältet mellan kontroll och utveckling. En policystudie av systematisk.t kvalitetsarbete $i$ kommunen, förskolan och fritidshemmet. Göteborg 2015

380 MIKAELA ÅBERG Doing Project Work.

The Interactional Organization of Tasks, Resources, and Instructions. Göteborg 2015

381 ANN-LOUISE LJUNGBLAD Takt och hållning - en relationell studie om det oberäkneliga i matematikundervisningen. Göteborg 2016

382 LINN HÅMAN Extrem jakt på hälsa. En explorativ studie om ortorexia nervosa. Göteborg 2016

383 EVA OLSSON On the impact of extramural English and CLIL on productive vocabulary.

Göteborg 2016

384 JENNIE SIVENBRING I den betraktades ögon. Ungdomar om bedömning i skolan. Göteborg 2016

385 PERNILLA LAGERLÖF Musical play. Children interacting with and around music technology.

Göteborg 2016

386 SUSANNE MECKBACH Mästarcoacherna. Att bli, vara och utvecklas som tränare inom svensk elitfotboll. Göteborg 2016

387 LISBETH GYLLANDER TORKILDSEN

Bedömning som gemensam angelägenhet - enkelt i retoriken, svärare i praktiken. Elevers och lärares förståelse och erfarenheter. Göteborg 2016

388 cancelled

389 PERNILLA HEDSTRÖM Hälsocoach $i$ skolan. En utvärderande fallstudie av en hälsofrämjande intervention. Göteborg 2016 
Editors: Åke Ingerman, Pia Williams and Elisabet Öhrn

390 JONNA LARSSON När fysik blir lärområde i förskolan. Göteborg 2016

391 EVA M JOHANSSON Det motsägelsefulla bedömningsuppdraget. En etnografisk studie om bedömning $i$ förskolekontext. Göteborg 2016

392 MADELEINE LÖWING Diamant-diagnoser $i$ matematik. Ett kartläggningsmaterial baserat på didaktisk ämnesanalys. Göteborg 2016

393 JAN BLOMGREN Den svårfängade motivationen: elever $i$ en digitaliserad lärmiljö. Göteborg 2016

394 DAVID CARLSSON Vad är religionslärarkunskap? En diskursanalys av trepartssamtal $i$ lärarutbildningen. Göteborg 2017

395 EMMA EDSTRAND Learning to reason in environmental education: Digital tools, access points to knowledge and science literacy. Göteborg 2017

396 KATHARINA DAHLBÄCK Svenskämnets estetiska dimensioner - - $i$ klassrum, kursplaner och lärares uppfattningar. Göteborg 2017

397 K GABRIELLA THORELL Framåt marsch! Ridlärarrollen frän dätid till samtid med perspektiv på framtid. Göteborg 2017

398 RIMMA NYMAN Interest and Engagement: Perspectives on Mathematics in the Classroom. Göteborg 2017

399 ANNIKA HELLMAN Visuella mölighetsrum. Gymnasieelevers subjektsskapande $i$ bild och medieundervisning. Göteborg 2017

400 OLA STRANDLER Performativa lärarpraktiker. Göteborg 2017

401 AIMEE HALEY Geographical Mobility of the Tertiary Educated - Perspectives from Education and Social Space. Göteborg 2017

402 MALIN SVENSSON Hoppet om en framtidsplats. Asylsökande barn i den svenska skolan. Göteborg 2017

403 CATARINA ANDISHMAND Fritidshem eller servicehem? En etnografisk studie av fritidshem i tre socioekonomiskt skilda områden. Göteborg 2017

404 MONICA VIKNER STAFBERG Om lärarblivande. En livsvärldsfenomenologisk studie av bildningsgångar in i läraryrket. Göteborg 2017

405 ANGELICA SIMONSSON Sexualitet $i$ klassrummet. Språkundervisning, elevsubjektivitet och heteronormativitet. Göteborg 2017

406 ELIAS JOHANNESSON The Dynamic Development of Cognitive and Socioemotional Traits and Their Effects on School Grades and Risk of Unemployment. Göteborg 2017
407 EVA BORGFELDT 'Det kean vara svart att förklara på rader". Perspektiv på analys och bedömning av multimodal textproduktion i arskurs 3. Göteborg 2017

408 GÉRALDINE FAUVILLE Digital technologies as support for learning about the marine environment. Steps toward ocean literacy. Göteborg 2018

409 CHARLOT'T SELLBERG Training to become a master mariner in a simulator-based environment: The instructors' contributions to professional learning. Göteborg 2018

410 TUULA MAUNULA Students' and Teachers' Jointly Constituted Learning Opportunities. The Case of Linear Equations. Göteborg 2018

411 EMMALEE GISSLEVIK Education for Sustainable Food Consumption in Home and Consumer Studies. Göteborg 2018

412 FREDRIK ZIMMERMAN Det tillatande och det begränsande. En studie om pojkars syn på studier och ungdomars normer kring maskulinitet. Göteborg 2018

413 CHRISTER MATTSSON Extremisten $i$ klassrummet. Perspektiv på skolans förväntade ansvar att förbindra framtida terrorism. Göteborg 2018

414 HELENA WALLSTRÖM Gymnasielärares mentorshandlingar. En verksambetsteoretisk studie om lärararbete i förändring. Göteborg 2018

415 LENA ECKERHOLM Lärarperspektiv på läsförståelse. En intervjustudie om undervisning $i$ àrskurs 4-6. Göteborg 2018

416 CHRISTOPHER HOLMBERG Food, body weight, and health among adolescents in the digital age: An explorative study from a health promotion perspective. Göteborg 2018

417 MAGNUS KARLSSON Moraliskt arbete $i$ förskolan. Regler och moralisk ordning $i$ barn-barn och vuxenbarn interaktion. Göteborg 2018

418 ANDREAS FRÖBERG Physical Activity among Adolescents in a Swedish Multicultural Area. An Empowerment-Based Health Promotion School Intervention. Göteborg 2018

419 EWA SKANTZ ÅBERG Children's collaborative technology-mediated story making. Instructional challenges in early childhood education. Göteborg 2018

420 PER NORDÉN Regnbågsungar: Familj, utbildning, fritid. Göteborg 2018

421 JENNY RENDAHL Vem och vad kan man lita på? Ungdomars förhållningssätt till budskap om mat och ätande utifrän ett forskarinitierat rollspel. Göteborg 2018

422 MARTINA WYSZYNSKA JOHANSSON Student experience of vocational becoming in upper secondary vocational education and training. Navigating by feedback. Göteborg 2018

423 MALIN NILSEN Barns och lärares aktiviteter med datorplattor och appar i förskolan. Göteborg 2018 
424 LINDA BORGER Investigating and V alidating Spoken Interactional Competence - Rater Perspectives on a Swedish National Test of English. Göteborg 2018

425 ANNA-MARIA FJELLMAN School choice, space and the geography of marketization - Analyses of educational restructuring in upper secondary education in Sweden.

Göteborg 2019

426 ANNELI BERGNELL Med kroppen som illustration: Hur förskolebarn prat-skapar naturvetenskap med hjälp av multimodala och kroppsförank rade förklaringar. Göteborg 2019

427 ANNE SOLLI Handling socio-scientific controversy: Students' reasoning through digital inquiry. Göteborg 2019

428 MARTIN GÖTHBERG Interacting - coordinating text understanding in a student theatre production.

Göteborg 2019

429 SUSANNE STRÖMBERG JÄMSVI Unpacking dominant discourses in bigher education language policy. Göteborg 2019

430 KURT WICKE Läroböcker, demokrati och medborgaskap. Konstruktioner i läroböcker $i$ sambällskunskap för gymnasiet. Göteborg 2019

431 KATARINA SAMUELSSON Teachers' Work in Times of Restructuring. On Contextual Influences for Collegiality and Professionality. Göteborg 2019

432 HELÉNE BERGENTOFT Lärande av rörelseförmåga $i$ idrott och hälsa ur ett praktikutvecklande perspektiv. Göteborg 2019

433 JANNA MEYER-BEINING Assessing writers, assessing writing: a dialogical study of grade delivery in Swedish higher education. Göteborg 2019

434 DAN FRANSSON Game demands and fatigue profiles in elite football - an individual approach-Implications of training and recovery strategies. Göteborg 2019

435 ELIN ARVIDSON Physiological responses to acute physical and psychosocial stress - relation to aerobic capacity and exercise training. Göteborg 2019

436 SUSANNE STAF Skriva historia-

literacyförväntningar och elevtexter $i$ historieämnet på mellanoch högstadiet. Göteborg 2019

437 VERONICA SÜLAU Vad händer i lärares kollegiala samtalspraktik? En studie av mötet mellan en nationell kompetensutvecklingsinsats och en lokal fortbildningspraktik. Göteborg 2019

438 MARIA OHLIN How to Make Bicycling SaferIdentification and Prevention of Serious Injuries among Bicyclists. Göteborg 2019

439 LINUS JONSSON An empowerment-based school physical activity intervention with adolescents in a disadvantaged community: A transformative mixed methods investigation. Göteborg 2019
440 ELIN NORDENSTRÖM Feedback and instructional guidance in healthcare simulation debriefings. Göteborg 2019

441 KATEŘINA ČERNÁ Nurses' work practice in chronic care: knowing and learning in the context of patients' selfmonitoring data.

Göteborg 2019

442 MARGARETHA HÄGGSTRÖM Estetiska erfarenheter i naturmöten. En fenomenologisk studie av upplevelser av skog, växtlighet och undervisning.

Göteborg 2020

443 PANAGIOTA NASIOPOULOU The professional preschool teacher under conditions of change - competence and intentions in pedagogical practises.

Göteborg 2020

444 ANNA TOROPOVA Teachers meeting the challenges of the Swedish school system. Agents within boundaries.

Göteborg 2020

445 ANNA LUNDBERG Att lära om proportionalitet $i$ den svenska skolan - en studie av läromedel, nationella prov samt lärprocesser $i$ klassrummet.

Göteborg 2020

446 ULF RYBERG Att urskilja grafiska aspekter av derivata - bur elevernas möjligheter pàverkas av innehällets behandling $i$ undervisningen.

Göteborg 2020

447 KASSAHUN WELDEMARIAM Reconfiguring Environmental Sustainability in Early Childhood Education: a Postanthropocentric Approach.

Göteborg 2020

448 ANNE KJELLSDOTTER Didactical

Considerations in the Digitalized Classroom.

Göteborg 2020

449 CARINA PETERSON V al, omröstning, styrning. En etnografisk studie om intentioner med, villker för och utfall av barns inflytande i förskolan.

Göteborg 2020

450 LOTTA WEDMAN The concept concept in mathematics education: A concept analysis.

Göteborg 2020

451 MARLENE SJÖBERG Samtal om undervisning $i$ naturvetenskap. Ämnesdidaktisk kollegial utveckling $i$ lärarutbildning och lärarprofession. Göteborg 2020

452 LENNART SVENSSON Kontextuell analys - En forskningsmetodologi och forskningsansats. Göteborg 2020

453 JOHN DOHLSTEN Vad möjliggör och begränsar en hällbar elitfriidrott? Aktionsforskning i elitidrottspraktiker inom Göteborgs frïdrottsförbund. Göteborg 2020

454 LENA SOTEVIK. Barbiebröllop och homohundar. Barn och barndomar $i$ relation till queerhet och (hetero)normativa livslinjer. Göteborg 2020. 
455 FRIDA SIEKKINEN. Att vara och inte vara. Elevpositioner(ingar) $i$ spänningsfältet mellan svenska och svenska som andraspråk. Göteborg 2021.

456 ANN-CHARLOTT WANK. Meningsskapande samtal. En studie om barns meningsskapande med fokus på processer och innehaill relaterat till förskolans praktik.

Göteborg 2021.

457 ANDREAS LUNDBERG ZACHRISSON.

Overuse injuries in Swedish elite athletics. Incidence, occurrence, athlete availability, and risk factors. Göteborg 2021.

458 ANNA NORRSTRÖM. Samtal under

lärarlagsmöten. Diskursorienteringar i den professionella praktiken. Göteborg 2021.

459 JOHANNA MELLÉN. Stability and Change. Policy, options, and choice in Swedish upper secondary education.

Göteborg 2021.

460 JONATAN JUNGMALM. Running-related injuries among recreational runners. How many, who, and why? Göteborg 2021.

461 ELISABETH OHLSSON. Den synliggjorda vokabulären och praktiken. Gymnasieelevers akademiska skrivande på svenska. Göteborg 2021.

462 VICTORIA ROLFE. Exploring socioeconomic inequality in educational opportunity and outcomes in Sweden and beyond. Göteborg 2021.

463 JONAS LINDBÄCK. Värsta bästa skolan. Om unga i förorten och segregationen i skolan. Göteborg 2021.

464 ANNE-MARIE CEDERQVIST. Seeing the parts, understanding the whole. A technology education perspective on teaching and learning in processes of analysing and designing programmed technological solutions. Göteborg 2021.

465 MARIE GRICE. Epistemic beliefs and conceptions of competence in education for sustainable development.

Göteborg 2021. 

Education for sustainable development is an educational response to urgent challenges within our ecological, economic, and social systems, such as climate change, natural resource depletion, poverty, and pandemics. Transnational organizations call for education to transform and take the lead in these global concerns. The transformation of education, society, and the individual poses epistemic as well as ethical questions.

The aim of this thesis is based on three concerns about education for sustainable development (ESD) and about transdisciplinary education specifically, but it raises issues relevant to practical pedagogical work and educational research in general. First, a concern is how students' epistemic beliefs (theories about knowledge and knowing) might impact how students orient themselves in transdisciplinary ESD. A second concern is what ESD competences teachers who aim to implement ESD may require. A third concern is related to ethical competence and how to approach the notion of action in ESD without indoctrination. A few new concepts are introduced as a supplement to and critique of action competence. Innovative educative moments are approached theoretically, exploring the learning-teaching nexus through moral literacy, action readiness and normative competence.

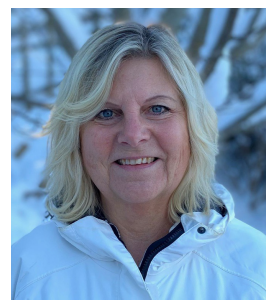

Marie Grice is a long-serving teacher at Uddevalla gymnasieskola. Her academic interests are epistemic and ethical issues in sustainability education. 